
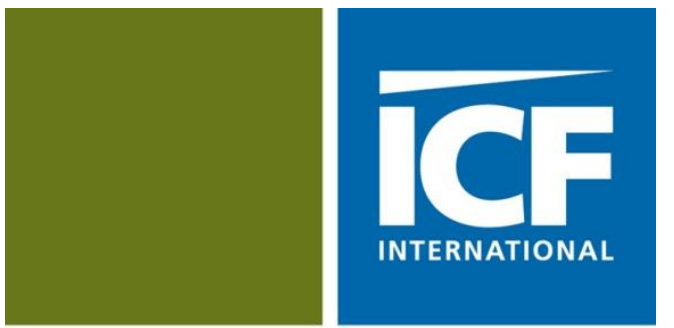

\title{
Waste Heat to Power Market Assessment
}

March 2015

Prepared for:

Oak Ridge National Laboratory

Prepared by:

Amelia Elson

Rick Tidball

Anne Hampson

ICF International 


\section{DOCUMENT AVAILABILITY}

Reports produced after January 1, 1996, are generally available free via the U.S. Department of Energy (DOE) Information Bridge.

Web site http://www.osti.gov/bridge

Reports produced before January 1, 1996, may be purchased by members of the public from the following source.

National Technical Information Service

5285 Port Royal Road

Springfield, VA 22161

Telephone 703-605-6000 (1-800-553-6847)

TDD 703-487-4639

Fax 703-605-6900

E-mail info@ntis.gov

Web site http://www.ntis.gov/support/ordernowabout.htm

Reports are available to DOE employees, DOE contractors, Energy Technology Data Exchange (ETDE)

representatives, and International Nuclear Information System (INIS) representatives from the following source.

Office of Scientific and Technical Information

P.O. Box 62

Oak Ridge, TN 37831

Telephone 865-576-8401

Fax 865-576-5728

E-mail reports@osti.gov

Web site http://www.osti.gov/contact.html

This report was prepared as an account of work sponsored by an agency of the United States Government. Neither the United States Government nor any agency thereof, nor any of their employees, makes any warranty, express or implied, or assumes any legal liability or responsibility for the accuracy, completeness, or usefulness of any information, apparatus, product, or process disclosed, or represents that its use would not infringe privately owned rights. Reference herein to any specific commercial product, process, or service by trade name, trademark, manufacturer, or otherwise, does not necessarily constitute or imply its endorsement, recommendation, or favoring by the United States Government or any agency thereof. The views and opinions of authors expressed herein do not necessarily state or reflect those of the United States Government or any agency thereof. 
Energy and Transportation Science Division

\title{
Waste Heat to Power Market Assessment
}

\author{
Prepared by \\ ICF International \\ 9300 Lee Highway \\ Fairfax, Virginia 22031
}

under Subcontract 4000130950

Date Published: March 2015

Prepared for

OAK RIDGE NATIONAL LABORATORY

Oak Ridge, Tennessee 37831-6283

managed by

UT-BATTELLE, LLC

for the

U.S. DEPARTMENT OF ENERGY

under contract DE-AC05-00OR22725 


\section{Table of Contents}

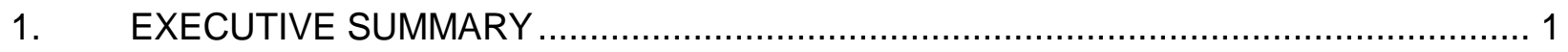

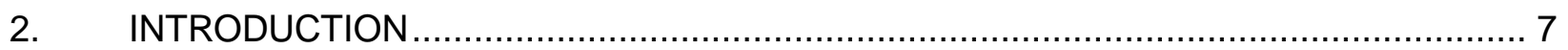

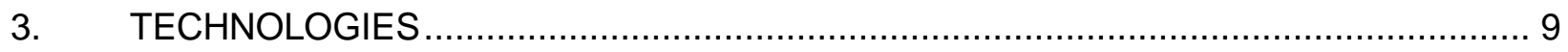

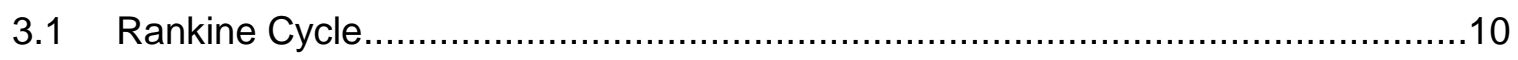

3.2 Emerging Technologies .......................................................................

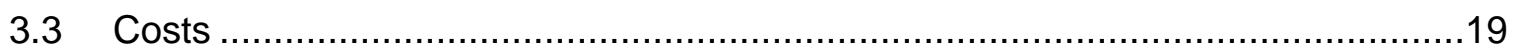

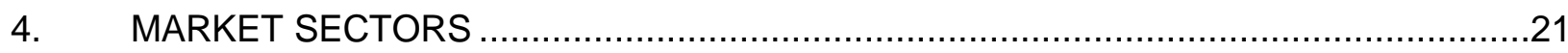

4.1 NAICS 324: Petroleum and Coal Products....................................................22

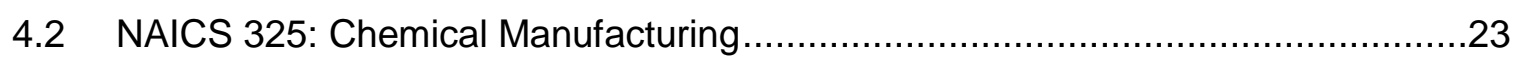

4.3 NAICS 327: Non-Metallic Mineral Products...................................................23

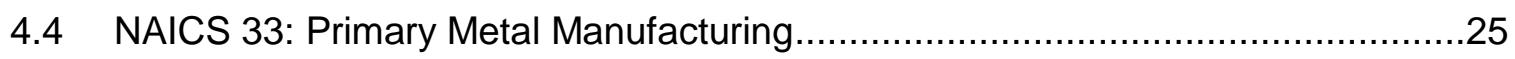

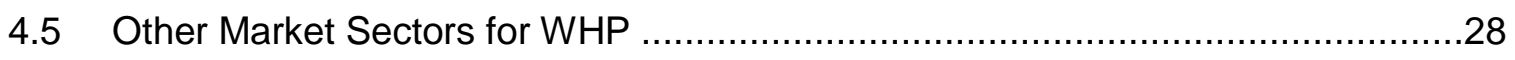

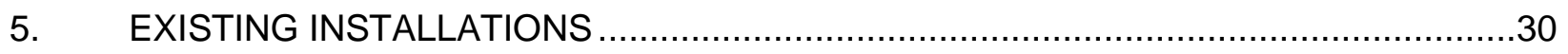

6. TECHNICAL POTENTIAL (ALL WASTE HEAT STREAM TEMPERATURES) ...............32

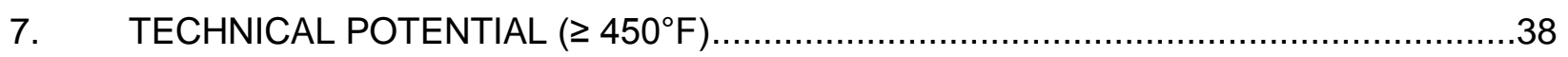

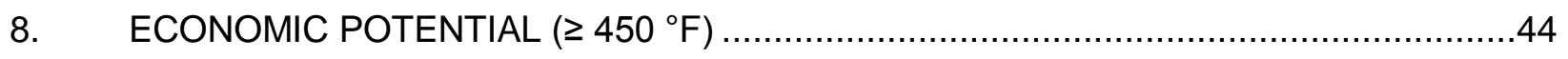

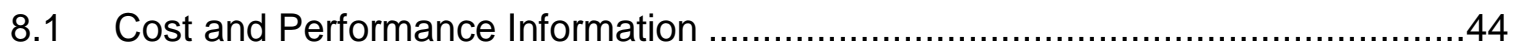

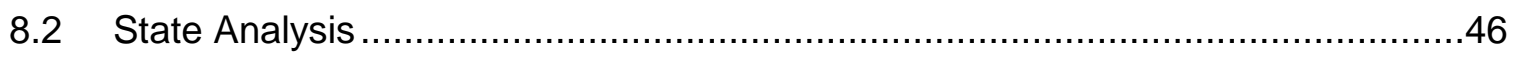

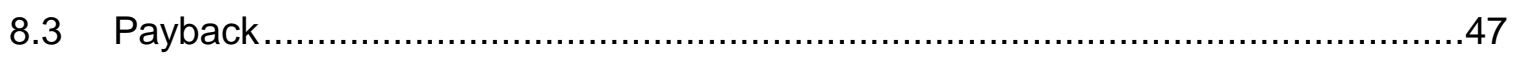

8.4 Expected Market Penetration ....................................................................50

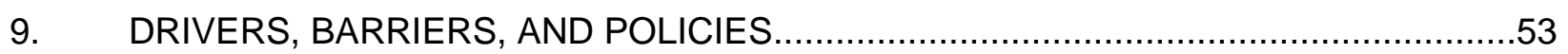

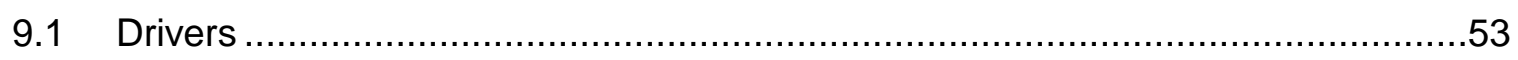

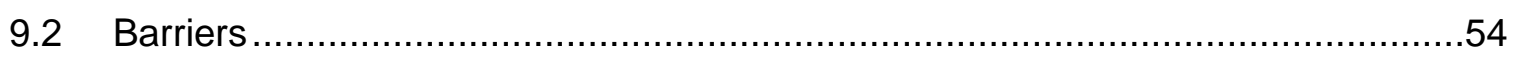

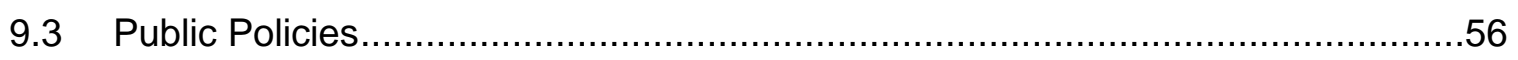

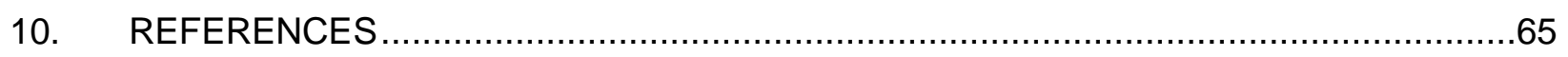

APPENDIX A. TECHNICAL AND ECONOMIC POTENTIAL METHODOLOGIES ................67

APPENDIX B. TECHNICAL POTENTIAL DATA ……...............................................

APPENDIX C. DEVELOPMENT OF WASTE HEAT INVENTORY DATA .............................74 


\section{Tables}

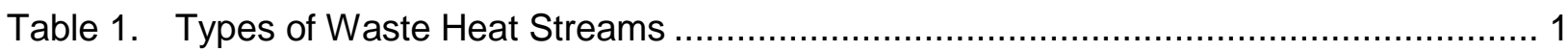

Table 2. Technical Potential with Breakdown by Payback Range $\left(\geq 450^{\circ} \mathrm{F}\right)$............................ 4

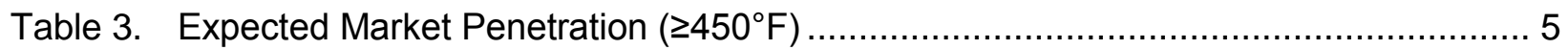

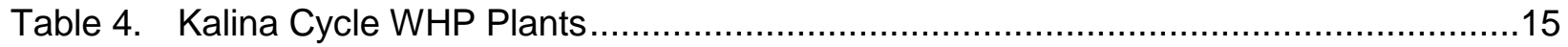

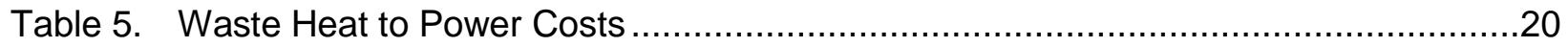

Table 6. Existing Waste Heat to Power Projects by State ……................................................

Table 7. Technical Potential for Electricity Generation .....................................................3

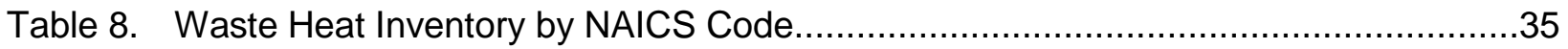

Table 9. Remaining WHP Technical Potential by NAICS Code (MW) .................................36

Table 10. Waste Heat to Power Technical Potential, No. of Facilities by NAICS .......................39

Table 11. Waste Heat to Power Technical Potential, Capacity by NAICS ...............................40

Table 12. Waste Heat to Power Technical Potential, Capacity by Sector.....................................41

Table 13. Waste Heat to Power Technical Potential, Capacity by State ....................................42

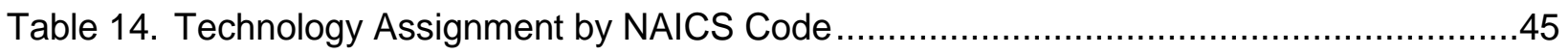

Table 15. Waste Heat to Power Cost Assumptions............................................................ 45

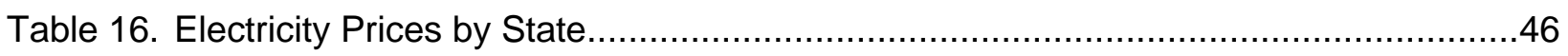

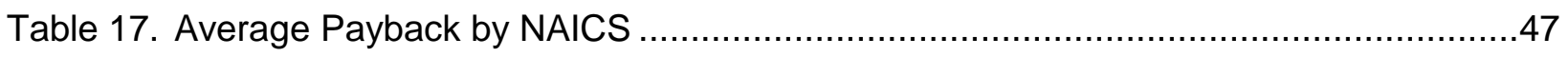

Table 18. WHP Technical Potential Capacity by Payback Range, NAICS …..........................48

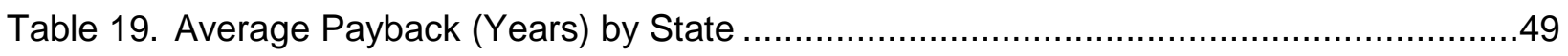

Table 20. WHP Technical Potential for ORC and SRC Technologies ..................................50

Table 22. Expected Market Penetration by Market Sector ……………................................51

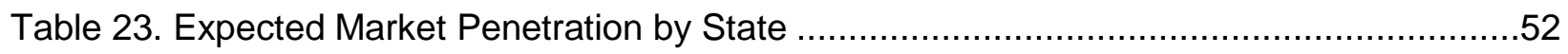

Table 24. Assumed Stack Gas Temperatures by Equipment Type ......................................68

Table 25. Assumed Stack Gas Temperatures by Refining Process ......................................69

Table 26. Assumed Exhaust Temperatures by Kiln Type.................................................

Table 27. Waste Heat to Power Technical Potential .............................................................

Table 28. ORNL 2004 Waste Heat Inventory by NAICS Code and Temperature Range $\left({ }^{\circ} \mathrm{F}\right) \ldots .75$

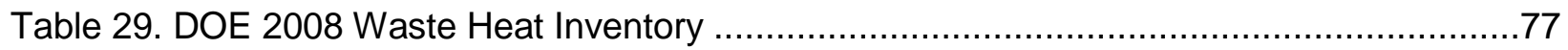

Table 30. Waste Heat Estimates for Non-Metallic Minerals Industry (TBtu / yr) .......................78

Table 31. Final Waste Heat Estimates for Primary Metals Industry (TBtu / yr) .........................79 


\section{Figures}

Figure 1. Remaining Technical Potential (MW) for WHP in the Manufacturing Sector ............... 2

Figure 2. Remaining Technical Potential and Market Penetration Estimates............................ 6

Figure 3. Major Components in a WHP System ............................................................ 9

Figure 4. Heat Engine Diagram.......................................................................... 9

Figure 5. Carnot (maximum) Heat Engine Efficiency ..........................................................10

Figure 6. Rankine Cycle Heat Engine ....................................................................

Figure 7. Organic Rankine Cycle Heat Engine with Regenerator ........................................12

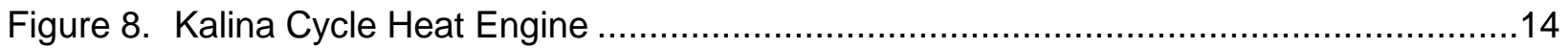

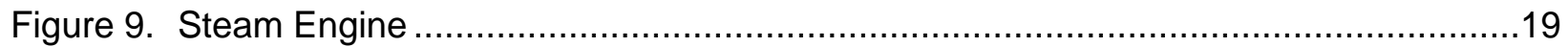

Figure 10. Manufacturing Sector Waste Heat Inventory by Industry and Temperature Range ...22

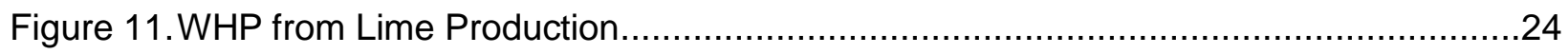

Figure 12. Existing Waste Heat to Power Projects by Sector ...............................................30

Figure 13. Remaining Technical Potential (MW) for WHP in the Manufacturing Sector..............37

Figure 14. WHP Technical Potential by State (number of sites) ….......................................41

Figure 15. WHP Technical Potential by State (capacity) ……...........................................

Figure 16. Sample Market Acceptance Survey Results .....................................................72 


\section{Executive Summary}

Waste heat to power (WHP) is the process of capturing heat discarded by an existing process and using that heat to generate electricity. In the industrial sector, waste heat streams are generated by kilns, furnaces, ovens, turbines, engines, and other equipment. In addition to processes at industrial plants, waste heat streams suitable for WHP are generated at field locations, including landfills, compressor stations, and mining sites. Waste heat streams are also produced in the residential and commercial sectors, but compared to industrial sites, these waste heat streams typically have lower temperatures and lower volumetric flow rates. The economic feasibility for WHP declines as the temperature and flow rate decline, and most WHP technologies are therefore applied in industrial markets where waste heat stream characteristics are more favorable.

This report provides an assessment of the potential market for WHP in the industrial sector in the United States. The types of industrial waste heat streams that are considered in this study are shown in Table 1.

Table 1. Types of Waste Heat Streams

\begin{tabular}{|l|l|}
\hline $\begin{array}{l}\text { Source of Waste } \\
\text { Heat Stream }\end{array}$ & Example (illustrations only, examples are not intended to be all inclusive) \\
\hline Thermal Process & $\begin{array}{l}\text { Energy recovered from a furnace, oven, or kiln, and subsequently used in } \\
\text { a combined heat and power (CHP) bottoming cycle. }\end{array}$ \\
\hline Mechanical Drive & Energy recovered from a natural gas pipeline compressor station. \\
\hline Other & $\begin{array}{l}\text { Waste heat recovered from industrial or other processes that generate } \\
\text { heat as a byproduct, such as exothermic reactions, incineration, and } \\
\text { pressure reduction. }\end{array}$ \\
\hline
\end{tabular}

The approach for completing the WHP potential analysis consisted of three steps:

1) Examine installed WHP capacity

2) Assess remaining technical potential

3) Estimate economic potential and expected market penetration

The installed capacity of WHP was estimated based on discussions with industry stakeholders and analysis of the CHP Installation Database maintained by ICF for Oak Ridge National Laboratory ${ }^{1}$. The database includes both topping cycle and bottoming cycle CHP installations. All bottoming cycle CHP entries in the database were

\footnotetext{
${ }^{1}$ CHP Installation Database. Maintained by ICF International for Oak Ridge National Laboratory. 2013. http://www.eea-inc.com/chpdata/index.html
} 
considered to be WHP facilities. ${ }^{2}$ For all types of waste heat streams included in this study, ICF identified an installed WHP capacity of 766 MW in the United States.

The next step in the analysis was to determine how much additional WHP capacity could be technically achieved. The technical potential was estimated using two approaches. The first approach was based on a top-down analysis that examined the potential to generate electricity from gaseous waste heat streams in the manufacturing sector. The second approach was based on a bottom-up analysis that examined waste heat streams at individual sites in the industrial sector.

The top-down analysis examined the waste heat inventory and subsequent technical potential in the manufacturing sector. This analysis yielded a remaining WHP technical potential of $14.6 \mathrm{GW}(14,594 \mathrm{MW})$. A breakdown of the technical potential based on the waste heat stream temperature range is shown in Figure 1. As indicated, 37 percent of the technical potential is below $450^{\circ} \mathrm{F}\left(12\right.$ percent $<300^{\circ} \mathrm{F}$ plus 25 percent in the 300 $450^{\circ} \mathrm{F}$ range), 53 percent is in the $450-1,200^{\circ} \mathrm{F}$ range, and 10 percent of the remaining technical potential is above $1,200^{\circ} \mathrm{F}$.

Figure 1. Remaining Technical Potential (MW) for WHP in the Manufacturing Sector (breakdown by waste heat stream temperature range)

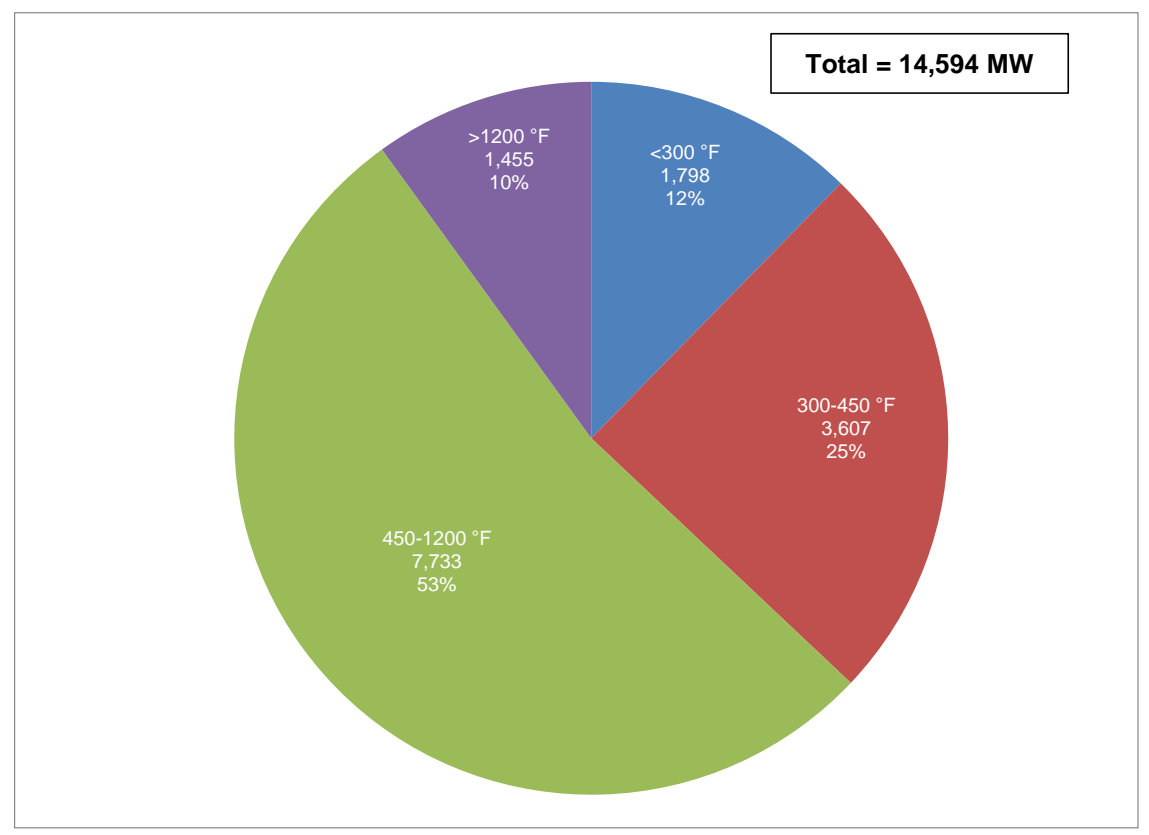

${ }^{2}$ Sources of waste heat are briefly discussed in Section 2, and WHP technologies are described in Section 3. 
The bottom-up approach involved developing an inventory of waste heat sources, identifying existing equipment and sites (e.g., manufacturing plants and compressor stations) and estimating the WHP capacity for each site. This approach is challenging and has limitations because there is no comprehensive database of industrial plants with data on industrial equipment and capacities. ICF was able to develop estimates, however, by examining a variety of databases, particularly databases focused on major waste heat sources.

The bottom-up approach was focused on waste heat stream temperatures above 450 ${ }^{\circ} \mathrm{F}$. This focus was selected, in part, because this temperature range represents the most economically viable market for WHP technologies that are now commercially available. Other considerations that contributed to this focus include the difficulty in obtaining accurate waste heat inventory data for lower temperature industrial processes, and the lack of a robust data set for technology performance and cost characteristics for WHP systems that operate at lower temperatures.

The bottom-up analysis identified a total estimated WHP technical potential of 8,840 MW at 2,946 sites. This total includes non-manufacturing sites such as landfills, gas processing plants and compressor stations. For manufacturing sites only, the total WHP technical potential estimated using the bottom-up approach is 7,064 MW. In comparison, the top-down analysis resulted in an estimated technical potential of 9,258 $\mathrm{MW}$ for waste heat stream temperatures above $450^{\circ} \mathrm{F}$. The data sources for the bottom-up analysis likely do not have comprehensive information for all sites in the manufacturing sector. Therefore, it is not surprising that the bottom-up analysis yields a technical potential result lower than the top-down analysis (7,064 MW compared to $9,258 \mathrm{MW})$.

Over 40 percent of the bottom-up technical potential total capacity (3,593 MW) was estimated to be in the petroleum refining sector. Natural gas pipeline transmission accounted for over 1,300 sites (46 percent of all sites), representing over 12 percent of the technical potential in terms of capacity $(1,102 \mathrm{MW})$. At a state level, Texas has the largest WHP technical potential (417 sites, $1,515 \mathrm{MW}, 17$ percent of capacity) followed by Louisiana and California (10 percent and 9 percent of technical potential capacity, respectively).

The economic potential and market penetration for WHP was evaluated using the detailed information developed for the bottom-up technical potential analysis. The bottom-up analysis includes waste heat stream temperatures above $450{ }^{\circ} \mathrm{F}$, which includes waste heat stream temperatures where WHP systems are expected to be more economically viable compared to low temperature $\left(<450^{\circ} \mathrm{F}\right)$ waste heat streams. 
In evaluating economic potential, various factors, such as capital costs, operating and maintenance (O\&M) costs, and the avoided cost of grid electricity are considered to estimate the simple payback for a WHP project. Table 2 shows the total technical potential capacity for waste heat temperatures greater than or equal to $450^{\circ} \mathrm{F}$ divided into four payback ranges. As indicated, $892 \mathrm{MW}$, or 10 percent, of WHP technical potential capacity has a payback of less than 2 years. A large portion of this capacity is in petroleum refining. Significant capacity also exists in primary metals, non-metallic minerals, and gas processing plants. The payback range with the largest total capacity is between 2 and 3 years, with 36 percent $(3,152 \mathrm{MW})$ of WHP technical potential in this range. There is also a large amount of WHP capacity with a 3-5 year payback, accounting for 31 percent, or 2,716 MW. Finally, 24 percent of total WHP capacity $(2,080 \mathrm{MW})$ has a payback of more than 5 years.

Table 2. Technical Potential with Breakdown by Payback Range $\left(\geq 450^{\circ} \mathrm{F}\right)$

\begin{tabular}{|c|c|c|}
\hline Payback (yrs) & \multicolumn{2}{|c|}{ Technical Potential } \\
\cline { 2 - 3 } & Capacity (MW) & Share of Total Capacity \\
\hline$<2$ & 892 & $10 \%$ \\
\hline $2-3$ & 3,152 & $36 \%$ \\
\hline $3-5$ & 2,716 & $31 \%$ \\
\hline$>5$ & 2,080 & $24 \%$ \\
\hline All & 8,840 & $100 \%$ \\
\hline
\end{tabular}

Market acceptance was calculated based on payback results (see Appendix A for further discussion of market acceptance calculations). This analysis shows that 33 percent $(2,904 \mathrm{MW})$ of the total technical potential $(8,840 \mathrm{MW})$ is anticipated to be accepted in the market (see Table 3). As expected, market penetration is highest for the lowest payback category (less than 2 years), with 56 percent of the total technical potential being accepted in the market. The lowest market penetration occurs among facilities with the highest payback (more than 5 years), with only 8 percent of total technical potential capacity resulting in viable projects. Facilities with paybacks less than 2 years account for 17.2 percent $(500 \mathrm{MW})$ of the total market penetration $(2,904$ $\mathrm{MW}$ ), and facilities with paybacks in the 2-3 year range account of 45.6 percent of the total market penetration. Collectively, facilities with paybacks under 5 years account for approximately 94 percent (2,736 MW) of total market penetration (2,904 MW). 
Table 3. Expected Market Penetration ( $\left.\geq 450^{\circ} \mathrm{F}\right)$

\begin{tabular}{|c|c|c|c|c|}
\hline \multirow{2}{*}{$\begin{array}{c}\text { Payback } \\
\text { (yrs) }\end{array}$} & \multirow{2}{*}{$\begin{array}{c}\text { Technical } \\
\text { Potential } \\
(\mathrm{MW})\end{array}$} & \multirow{2}{*}{$\begin{array}{c}\text { Market } \\
\text { Penetration } \\
(\mathrm{MW})\end{array}$} & \multicolumn{2}{|c|}{ Market Penetration (\%) } \\
\hline & & & $\begin{array}{c}\text { Share of Technical Potential } \\
\text { Within Payback Range }\end{array}$ & $\begin{array}{c}\text { Share of Total Market } \\
\text { Penetration }\end{array}$ \\
\hline$<2$ & 892 & 500 & $56 \%$ & $17.2 \%$ \\
\hline $2-3$ & 3,152 & 1,324 & $42 \%$ & $45.6 \%$ \\
\hline $3-5$ & 2,716 & 912 & $34 \%$ & $31.4 \%$ \\
\hline$>5$ & 2,080 & 168 & $8 \%$ & $5.8 \%$ \\
\hline All & 8,840 & 2,904 & $33 \%$ & $100 \%$ \\
\hline
\end{tabular}

Further examination of the market potential shows that the petroleum refining sector has the largest expected market penetration, with 1,488 MW, followed by primary metals (850 MW), non-metallic minerals (385 MW), oil and gas extraction (73 MW), and pipeline transportation (77 MW). These same industries have the highest WHP technical potential. At a state level, Texas has the largest expected market penetration with $513 \mathrm{MW}$, followed by California (402 MW) and Louisiana (242 MW).

Figure 2 provides a comparison of the technical potential for all waste heat stream temperatures (14.6 GW), technical potential for waste heat stream temperatures $\geq 450$ ${ }^{\circ} \mathrm{F}(8.8 \mathrm{GW})$, and market penetration potential for waste heat stream temperatures $\geq$ $450{ }^{\circ} \mathrm{F}(2.9 \mathrm{GW})$. While the market penetration is estimated at $2.9 \mathrm{GW}$, there are many factors that influence the installation of WHP technologies, and these factors need to be carefully evaluated at each site. These factors include:

- Waste heat recovery options. In general, the least expensive option for utilizing waste heat is to re-use this energy in an on-site thermal process. If it is not feasible to recover energy from a waste heat stream for another thermal process, then a WHP system may be an economically attractive option.

- Cost of grid electricity. A fundamental driver that impacts the market penetration of WHP is the difference between the cost of electricity produced by a WHP system and the cost of grid electricity. In general, states that have relatively high grid electricity prices (e.g., California and several Northeastern states) are more favorable for WHP technologies. The results in this study are based on state average energy prices. It is important to recognize that energy prices vary within states, and the results presented in this study are not intended to be applicable for specific utility service territories within states.

- Integration of WHP. WHP systems require close coupling with a high temperature industrial process, and there can be site specific challenges. Depending on the application, a WHP system may be required to handle corrosive or particulate-laden exhaust streams, operate with batch or continuous 
manufacturing processes, or be integrated into complex process control schemes.

- Available financial incentives. Incentives may be available that improve the economics for WHP. State programs that include WHP in portfolio standards are an important incentive for WHP, among other available incentives.

\section{Figure 2. Remaining Technical Potential and Market Penetration Estimates}

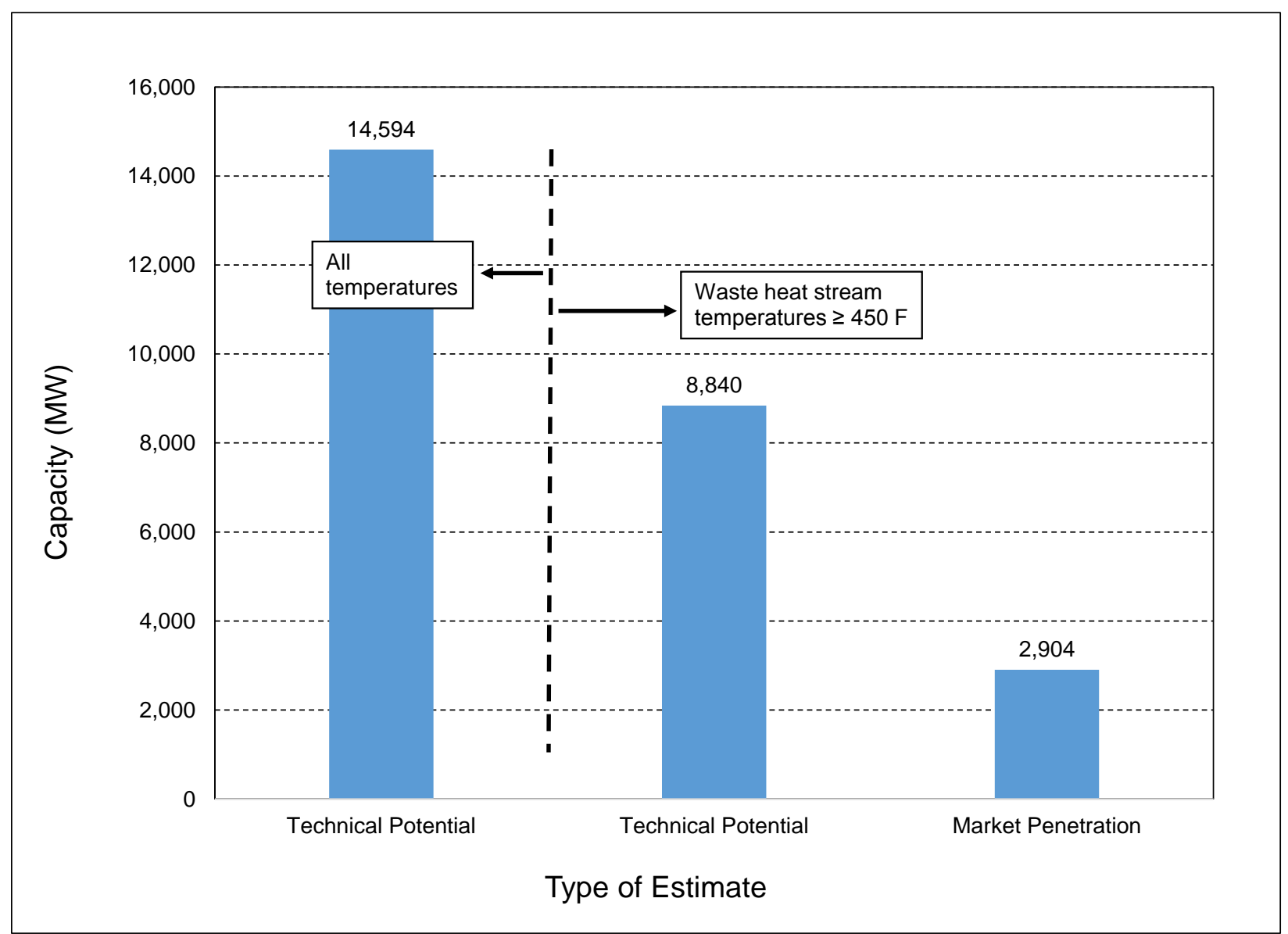

Notes: 1) The technical potential estimate for all temperatures is based on the industrial manufacturing sector.

2) The technical potential estimate for temperatures $\geq 450^{\circ} \mathrm{F}$ includes the manufacturing sector plus non-manufacturing sectors that offer opportunities for WHP. 


\section{Introduction}

Waste heat to power (WHP) technologies produce electricity by capturing some form of waste heat, typically at an industrial facility, and then converting this waste heat to electricity. WHP systems have a single purpose, which is the production of electricity. The waste heat sources that drive WHP technologies can be divided into three categories that have unique attributes, both in terms of viable technologies and legal definitions that may apply:

- Waste heat from a thermal process - Energy can be recovered from a furnace, oven, kiln, and other industrial processes ${ }^{3}$ and converted to electricity using a thermodynamic process such as a Rankine cycle steam turbine. ${ }^{4}$ This configuration for a WHP system is also referred to as a combined heat and power (CHP) bottoming cycle. In a CHP bottoming cycle, fuel is combusted to provide thermal input to an industrial process equipment like a kiln or furnace, and the heat rejected from the process is then captured and used for power production.

- Waste heat from a mechanical drive - Engines and turbines can be used to drive mechanical shafts that in turn spin compressors, pumps, and electrical generators. An example is a pipeline compressor station that utilizes a gas turbine to drive a compressor that in turn moves natural gas through a pipeline. Waste heat can be recovered from the gas turbine exhaust and used to generate electricity. This configuration for a WHP system is not classified as CHP because there is no industrial process that utilizes the thermal energy (heat).

- Waste heat from other systems - Unlike bottoming cycle CHP which combusts a fuel to generate heat for a thermal application and then uses the leftover waste heat to generate power, some industrial processes generate heat as a byproduct. Capture and use of that heat for a thermal purpose is classified as waste heat recovery, while capture and use of that heat to make power is called waste heat to power. Operations that use byproduct heat to make power include exothermic reactions like those used in the manufacture of fertilizers, incineration of sewage sludge, heat released from pressure relief valves, and other processes that produce heat not for a thermal purpose but as a result of their operation.

\footnotetext{
3 Processes include calciners, kilns, flares, incinerators, ovens, reciprocating engines, regenerative oxidizers, thermal oxidizers, and exhaust from petroleum refining.

${ }^{4}$ Other thermodynamic processes, such as organic Rankine cycle (ORC) and Kalina cycles, can be used, particularly for lower temperature waste heat streams.
} 
There is no single definition for WHP, and various definitions have been used by regulators, government agencies, manufacturers, and trade associations. In this report, the WHP market is defined to include all waste heat streams described in the preceding bullets.

The purpose of this report is to provide a baseline assessment of the potential, both technical and economic, for WHP in the United States. This report is organized as follows:

- Section 1 - Executive Summary

- Section 2 - Introduction

- Section 3 - Technologies

- Section 4 - Market Sectors

- Section 5 - Existing Installations

- Section 6 - Technical Potential (all waste heat stream temperatures)

- Section 7 - Technical Potential (waste heat stream temperatures $\geq 450^{\circ} \mathrm{F}$ )

- Section 8 - Economic Potential (waste heat stream temperatures $\geq 450^{\circ} \mathrm{F}$ )

- Section 9 - Drivers, Barriers, and Policies

- Section 10 - References 


\section{Technologies}

From an energy conversion perspective, a WHP system consists of two major components: 1) a heat engine and 2) an electrical generator (see Figure 3). In thermodynamic terms, the heat engine converts energy (heat) in the waste heat stream to mechanical energy (work). The mechanical energy (e.g., a rotating shaft) is then used to generate power in an electrical generator.

Figure 3. Major Components in a WHP System

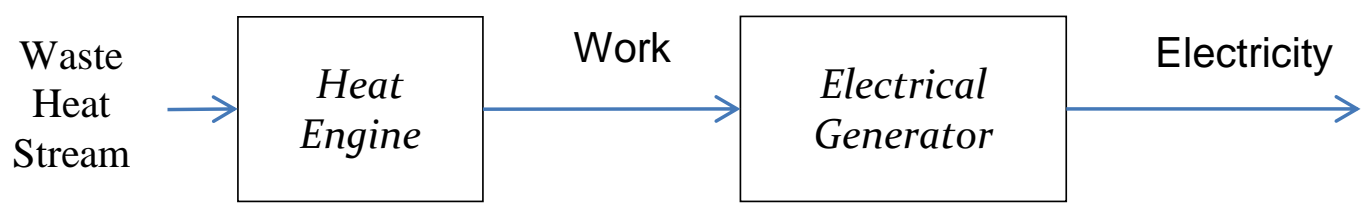

In a heat engine, heat flows from a hot reservoir to a cold reservoir, and the temperature difference between these reservoirs governs the efficiency of the heat engine. The maximum, or Carnot, efficiency $(\eta)$ is defined to be (see Figure 4 for illustration):

$$
\eta=W / Q_{H}=1-\left(T_{C} / T_{H}\right)
$$

where,

$$
\begin{aligned}
& \text { W - work done by the system (energy exiting the system as work) } \\
& Q_{H} \text { - heat put into the system (heat energy entering the system) } \\
& T_{C} \text { - absolute temperature of the cold reservoir } \\
& T_{H} \text { - absolute temperature of the hot reservoir }
\end{aligned}
$$

Figure 4. Heat Engine Diagram

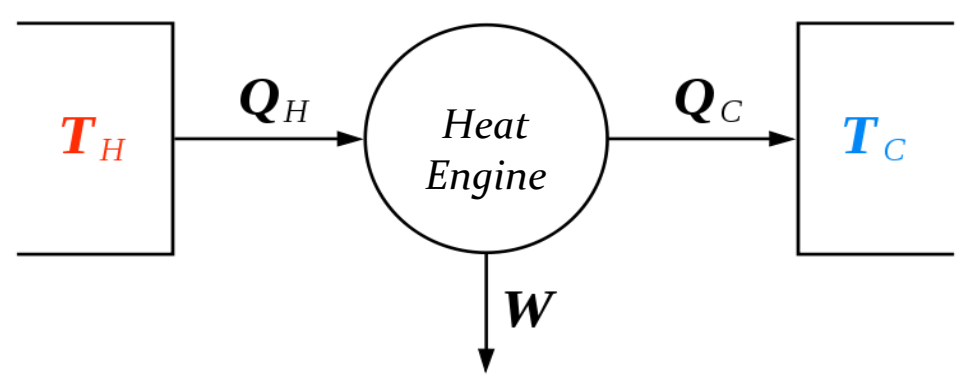

The maximum efficiency for a heat engine is shown in Figure 5. Efficiency curves are shown at heat sink (i.e., cold reservoir) temperatures of 60 and $300^{\circ} \mathrm{F}$. 
Figure 5. Carnot (maximum) Heat Engine Efficiency

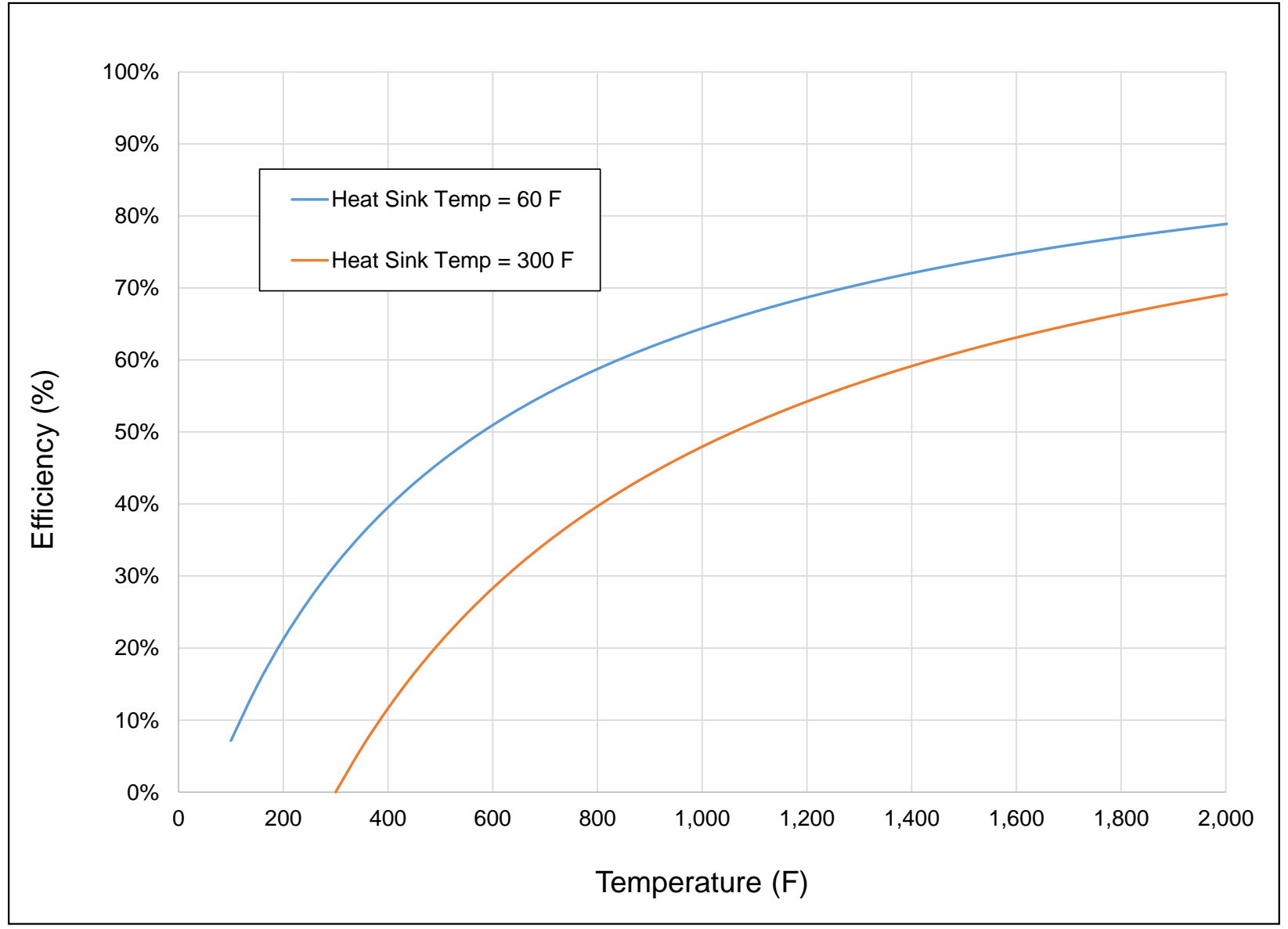

For WHP technologies that are commercially available, the actual efficiencies are much lower than the theoretical Carnot efficiencies. In actual WHP systems, there are irreversible thermodynamic losses that push the efficiencies downward. In addition, energy is also lost in the electrical generation process.

The Rankine thermodynamic cycle is commonly used for WHP systems. Variations of this cycle include the steam Rankine cycle (SRC), organic Rankine cycle (ORC), Kalina cycle, and supercritical carbon dioxide $\left(\mathrm{CO}_{2}\right)$ cycle. These Rankine cycles are briefly described on the following pages. After the Rankine cycle information, there is a short discussion of emerging WHP technologies followed by a summary of WHP costs.

\subsection{Rankine Cycle}

In a Rankine cycle (either SRC or ORC), a liquid working fluid is pumped to elevated pressure before entering a heat recovery boiler as illustrated in Figure 6 . The pressurized fluid is vaporized using energy captured from a waste heat stream, and then expanded to lower temperature and pressure in a turbine, generating mechanical 
power that can drive an electric generator. The low pressure working fluid is then exhausted to a condenser where heat is removed by condensing the vapor back into a liquid. The condensate from the condenser is then returned to the pump and the cycle is repeated. For WHP applications, the Rankine cycle efficiency typically ranges from 3050 percent of the Carnot theoretical efficiency. For example, if the Carnot efficiency is calculated to be 60 percent for a $900^{\circ} \mathrm{F}$ heat source, the actual efficiency achieved will likely be in the range of 18-30 percent.

\section{Figure 6. Rankine Cycle Heat Engine}

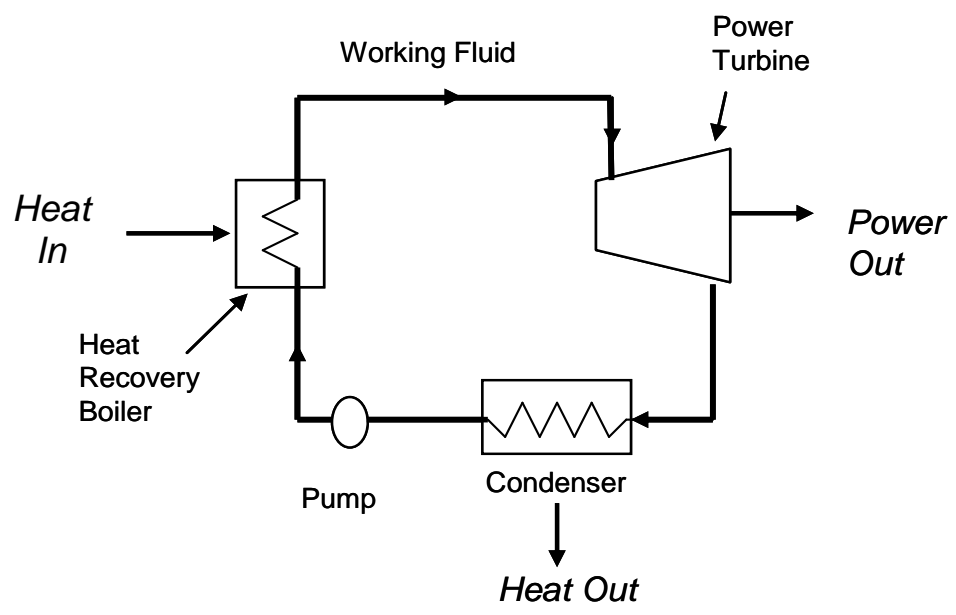

Most commercially available WHP technologies in the U.S. are based on either the steam Rankine cycle (SRC) or the organic Rankine cycle (ORC). The Kalina cycle and supercritical $\mathrm{CO}_{2}$ cycle are variations of the Rankine cycle that have recently entered the market. For SRC systems, the working fluid is water, and for ORC systems the working fluid is a hydrocarbon, hydrofluorocarbon, or ammonia. The Kalina cycle uses a combination of water and ammonia, and the supercritical $\mathrm{CO}_{2}$ cycle uses carbon dioxide.

\subsubsection{Steam Rankine Cycle (SRC)}

The most common example of the Rankine cycle is the steam turbine, or steam Rankine cycle (SRC). In a SRC system, the working fluid is water, and steam is created to drive a turbine.

Steam turbines are a mature and versatile technology, and have been in use for more than 100 years. Most of the electricity produced in the United States is generated by conventional steam turbine power plants that use coal, natural gas, or nuclear energy as a fuel source. In WHP applications, the capacity of steam turbines can range from $50 \mathrm{~kW}$ to several hundred megawatts. 


\subsubsection{Organic Rankine Cycle (ORC)}

Organic Rankine cycle (ORC) systems are similar to SRC systems, but instead of water the working fluid is a hydrocarbon, hydrofluorocarbon, or ammonia. One configuration of an ORC system is shown Figure 7. This ORC design consists of an evaporator ("boiler"), expander ("turbine"), preheater, condenser, and regenerator. The regenerator improves efficiency by pre-heating the working fluid with energy that would otherwise be rejected. The working fluid in an ORC machine typically has a lower boiling point than water, which allows ORC systems to operate with relative low temperature heat sources - sometimes as low as $200^{\circ} \mathrm{F}$ or below ${ }^{5}$. Example working fluids that have been used in ORC systems include silicone oil, propane, isopentane, isobutane, xylene, and toluene. The working fluid is chosen based on the best thermodynamic match to the available heat source. An example of a modern, modular ORC is ElectraTherm's Green Machine which uses Pentafluoropropane as the working fluid. ${ }^{6}$

Figure 7. Organic Rankine Cycle Heat Engine with Regenerator

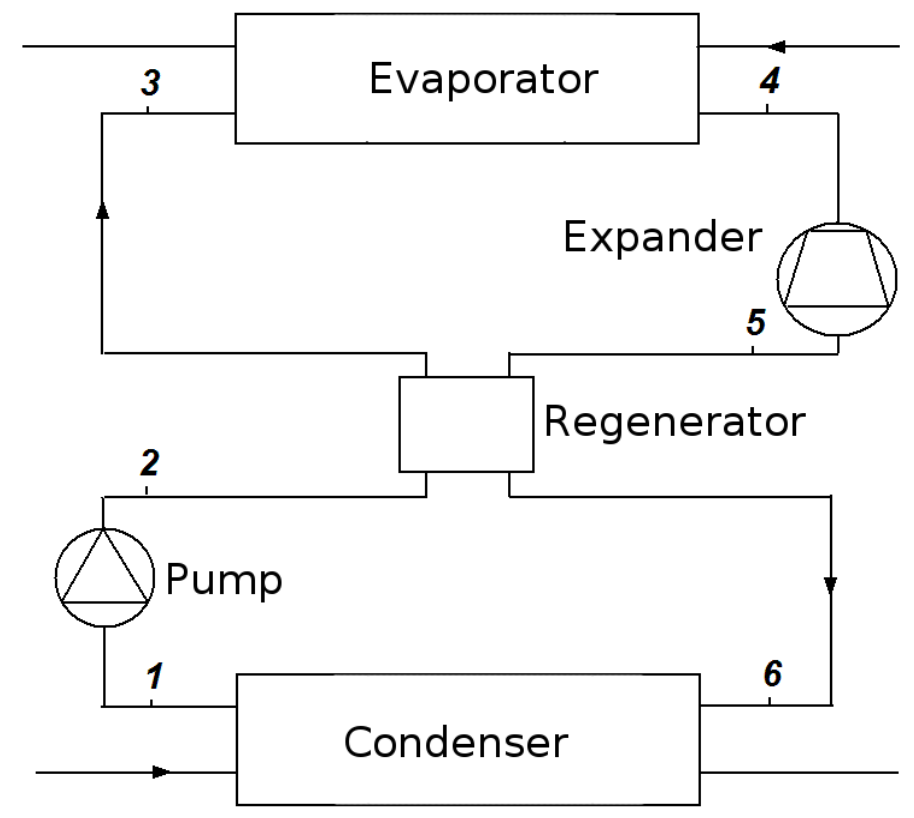

In comparison with water, the fluids used in ORCs have thermodynamic properties (e.g., boiling point characteristics) that enable operation with waste heat sources that have temperatures near $200^{\circ} \mathrm{F}$, or even lower. Operation at such low temperatures, however, is typically only cost effective when using a liquid waste stream, which allows the use of

\footnotetext{
${ }^{5}$ ElectraTherm's Green Machine and the Ener-G-Rotors ORCA ${ }^{\mathrm{TM}}$ systems are examples of modular ORCs that have the ability to operate with relatively low temperature heat sources.

${ }^{6}$ www.electratherm.com
} 
a liquid-to-liquid heat exchanger. ${ }^{7}$ For gaseous heat sources, such as hot exhaust from an industrial process, a temperature of at least $500^{\circ} \mathrm{F}$ is typically required for commercially available technologies.

While both cycles are classified as Rankine cycle heat engines, there are a few key distinctions between SRC and ORC systems:

- Heating and expansion for an ORC occurs with the application of heat to an evaporator, not a boiler.

- The ORC condenser is not operated at a vacuum or at sub-atmospheric pressure, which helps to avoid introducing air into the system.

ORC systems are commonly used to generate power in geothermal power plants, and more recently, in pipeline compressor heat recovery applications. In these, and other, ORC applications, electric generation efficiencies range from around 8 percent with waste heat sources at $300^{\circ} \mathrm{F}$, to around 15 percent with waste heat sources near 800 ${ }^{\circ} \mathrm{F}$. As expected, these efficiencies are lower than the maximum Carnot efficiencies. For example, the Carnot efficiency for a heat source at $300{ }^{\circ} \mathrm{F}$ and a heat sink at $77^{\circ} \mathrm{F}$ is about 30 percent.

\subsubsection{Kalina Cycle}

The Kalina cycle is a variation of the Rankine cycle, using a binary fluid pair as the working fluid (typically water and ammonia). Figure 8 shows a schematic view of a Kalina cycle power plant for waste heat. In addition to the classic 4-stage Rankine cycle components (evaporator, turbine, condenser, compressor) there is a distillationcondensation subsystem consisting of a series of separators, heat exchangers, and pumps.

\footnotetext{
${ }^{7}$ For equivalent levels of heat transfer, a liquid-to-liquid heat exchanger is much smaller, and less expensive, compared to a gas-to-liquid heat exchanger.
} 
Figure 8. Kalina Cycle Heat Engine

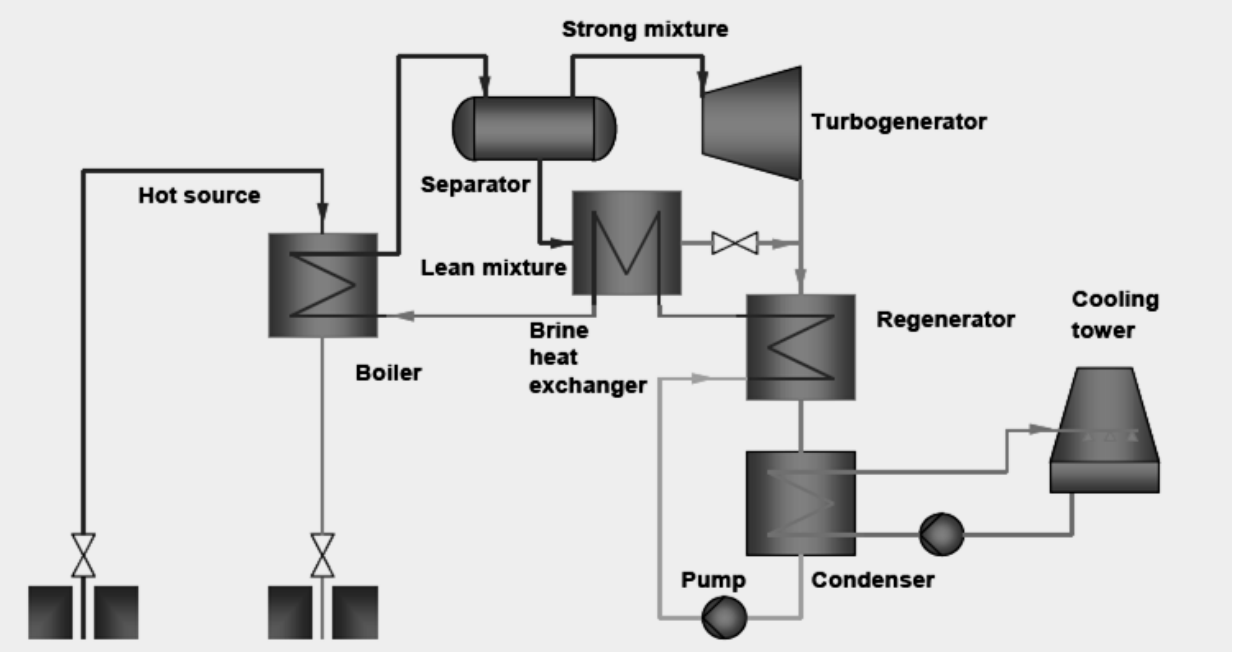

Source: Thekdi, 2007

Like SRC/ORCs, the Kalina cycle is specifically designed for converting thermal energy to mechanical power, optimized for use with thermal sources that are at a relatively low temperature compared to the heat sink (or ambient) temperature. The primary difference between a single fluid Rankine cycle and the Kalina cycle is the temperature profile during boiling and condensation. In the SRC and ORC cycles, the temperature remains constant during boiling. As heat is transferred to the working fluid, its temperature slowly increases to the boiling temperature, at which point the temperature remains constant until all the fluid has evaporated. In contrast, a binary mixture of water and ammonia (each of which has a different boiling point) will increase in temperature during evaporation. This process allows better thermal matching with the waste heat source, and with the cooling medium in the condenser in counter flow heat exchangers. Consequently, these systems have relatively good energy efficiency performance compared to other WHP thermodynamic cycles. Operating efficiencies for a Kalina cycle WHP system are around 15 percent with a heat source temperature of $300{ }^{\circ} \mathrm{F}$. Because the phase change from liquid to steam is not at a constant temperature, the temperature profiles of the hot and cold fluids in a heat exchanger can be closer, thus increasing the overall efficiency. Because of these performance characteristics, the Kalina cycle is well suited for geothermal power plants, where the hot fluid is often below $212^{\circ} \mathrm{F}$. The Kalina cycle was patented in 1982, and the first power plant based on the Kalina cycle was commissioned in Canoga Park, California in 1992. Table 4 shows several Kalina cycle WHP plants. 
Table 4. Kalina Cycle WHP Plants

(list is for illustrative purposes, and is not necessarily all inclusive) ${ }^{8,9}$

\begin{tabular}{|l|l|l|l|l|}
\hline Name & Country & Commissioned & Output (MW) & Heat source \\
\hline Canoga Park & USA & 1992 & 6.5 & Nuclear waste heat \\
\hline Fukuoka & Japan & 1998 & 4.0 & Waste incineration \\
\hline Sumitomo Metals & Japan & 1999 & 3.5 & Waste heat (steel mill) \\
\hline Husavik & Iceland & 2000 & 2.0 & Geothermal \\
\hline Fuji Oil & Japan & 2005 & 3.9 & Waste heat (refinery) \\
\hline Bruschal & Germany & 2009 & 0.6 & Geothermal \\
\hline Unterhaching & Germany & 2009 & 3.5 & Geothermal \\
\hline Shanghai Expo & China & 2010 & 0.05 & Solar hot water \\
\hline Quingshui & Taiwan & 2011 & 0.05 & Geothermal \\
\hline Khan Cement & Pakistan & Under construction & 8.5 & Waste heat (cement plant) \\
\hline Start Cement & UAE & Under construction & 4.8 & Waste heat (cement plant) \\
\hline
\end{tabular}

\subsubsection{Supercritical $\mathrm{CO}_{2}$ Cycle}

Another variation of the Rankine Cycle is the supercritical $\mathrm{CO}_{2}\left(\mathrm{sCO}_{2}\right)$ cycle, which utilizes carbon dioxide in place of water/steam for a heat-driven power cycle. The $\mathrm{sCO}_{2}$ cycle in its simplest form consists of the following main components: waste heat and recuperator heat exchangers, condenser, system pump, and turbine. Ancillary components (valves and sensors) provide system monitoring and control. Heat energy is introduced through a waste heat exchanger installed into a customer's exhaust stack, boiler or turbine exhaust duct, hot process gas or liquid line, or solar thermal concentrator. The fluid in either a liquid or dense supercritical state is compressed by a fluid pump/compressor. The high pressure fluid is preheated in the recuperator with residual heat from the expanded fluid discharged from the turbine. The preheated fluid is raised to its highest temperature by transferring heat from the process - either exhaust or other heat source(s). Next, the high temperature/pressure fluid is expanded through a turbine, which drives a motor/generator and the pump/compressor. As the $\mathrm{sCO}_{2}$ cycle pressure ratio is relatively low, the fluid at the turbine exit retains sufficient heat to warrant recovery in the recuperator. Finally, the fluid is cooled back to the pump/compressor inlet temperature in the condenser/cooler heat exchanger. Both aircooled and water-cooled systems are applicable.

8 Data source for first ten rows of table: Kalina Cycle Power Systems in Waste Heat Recovery Applications, http://www.globalcement.com/magazine/articles/721-kalina-cycle-power-systems-in-wasteheat-recovery-applications, accessed October 2014.

9 Data for cement plants (bottom two rows): International Finance Corporation, Waste Heat Recovery for the Cement Sector, page 29, plants under construction by FLSmidth, 2014. 
Carbon dioxide is a low-cost working fluid that is non-toxic and non-flammable. The high fluid density of $\mathrm{SCO}_{2}$ enables compact turbomachinery designs, and permits the use of compact heat exchanger technology to reduce system component size, cost, and system footprint. Due to its high thermal stability and non-flammability, the exhaust heat exchanger can be placed in direct contact with high temperature heat sources, typically from 400 to $1,000 \stackrel{\circ}{\circ}$ (or higher), eliminating an intermediate heat transfer loop.

\subsection{Emerging Technologies}

There are a number of advanced technologies in the R\&D stage that could, in the future, provide additional options for direct power generation from waste heat sources. These technologies include thermoelectric generators, piezoelectric generators, thermionic devices, thermo-photovoltaic generators, Stirling engines, and innovative concepts for steam engines. These systems range in terms of commercial readiness in the United States, although some - such as the Kalina Cycle - have achieved relative success internationally. A few have undergone prototype testing in applications such as heat recovery in automotive vehicles and from co-produced liquid in oil and gas wells.

\subsubsection{Thermoelectric Generation ${ }^{10}$}

Thermoelectric generation converts a heat differential directly into electricity. In a phenomenon known as the Seebeck effect, when two different semiconductor materials are subjected to a heat source and heat sink, a voltage is created between the two semiconductors. In the reverse of this process, thermoelectric materials can also be used for cooling or heating by applying electricity to dissimilar semiconductors.

Thermoelectric technology has existed for many years (the thermoelectric effect was first discovered in 1821), but has seen limited use due to low efficiencies and high cost. Most thermoelectric generation systems in use have efficiencies of 2 to 5 percent; these have mainly been used to power instruments on spacecraft or in very remote locations. However, recent advances in nanotechnology have enabled advanced thermoelectric materials that might achieve conversion efficiencies of 15 percent or greater.

A study by PNNL and BCS examined the opportunity for thermoelectric generation in various industrial waste heat streams and identified performance requirements and RD\&D needs (BCS 2006). The study concluded that advanced thermoelectric generation would be appropriate in medium to high temperature, high flow rate exhaust streams where facilities have little use for recovered waste heat. Two example opportunities are glass furnaces and molten metal furnaces. Before thermoelectric

\footnotetext{
10 Alphabet Energy is one company that is developing thermoelectric power generation technology. Alphabet Energy announced a new product in October 2014, http://www.alphabetenergy.com/pressreleases/alphabet-energy-introduces-worlds-powerful-thermoelectric-generator/.
} 
materials can be used in these applications, advances are needed in both TE production technology and in heat transfer systems. Thermoelectric generation costs have been estimated at $\$ 30 /$ watt (DOE, 2008), which is an order of magnitude higher than costs that are currently competitive for power generation in the industrial sector.

Alphabet Energy introduced a new thermoelectric generator this year that has achieved an order of magnitude cost reduction from the $\$ 30 /$ watt cited above. It attaches to an exhaust stack and generates up to $25 \mathrm{~kW}$ e per 1,000 kWe engine, saving 52,500 liters of diesel fuel per year per engine, and providing the highest efficiency yet for industrial thermoelectric applications ${ }^{11}$.

\subsubsection{Piezoelectric Power Generation}

Piezoelectric Power Generation is an option for converting low temperature waste heat

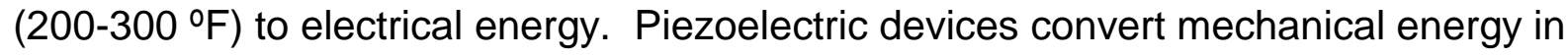
the form of ambient vibrations to electrical energy. A piezoelectric thin film membrane can take advantage of oscillatory gas expansion to create a voltage output. A recent study (DOE, 2008) identified several technical challenges associated with piezoelectric power generation technologies:

- Low efficiency - Piezoelectric power generation technology is only about 1 percent efficient

- High internal impedance

- Complex oscillatory fluid dynamics within the liquid/vapor chamber

- Need for long term reliability and durability

- High costs

\subsubsection{Thermionic Generation}

Thermionic devices operate similar to thermoelectric devices; however, whereas thermoelectric devices operate according to the Seebeck effect, thermionic devices operate via thermionic emission. In these systems, a temperature difference drives the flow of electrons through a vacuum from a metal to a metal oxide surface. One key disadvantage of these systems is that they are limited to applications with high temperatures above $1,800^{\circ} \mathrm{F}$.

\footnotetext{
${ }^{11}$ http://www.alphabetenergy.com/press-releases/alphabet-energy-introduces-worlds-powerfulthermoelectric-generator/
} 
MIT, with the Salt Lake City-based company ENECO, has developed a semiconductor technology that converts heat into electricity using solid state thermionics, a combination of thermoelectrics and thermionics. ENECO produced a single, solid state device that exhibited up to 35 percent of Carnot efficiency at much lower temperatures $\left(200-600^{\circ} \mathrm{F}\right)$ making it suitable for waste heat applications. The device is a sandwich of three layers of semiconductor. One of the outer layers is heated and the other is kept at ambient temperature. The middle layer is an insulator that maintains the temperature difference. The heat causes electrons to eject, generating an electrical current. (PNNL, 2006) The concept received research support from the Department of Defense and the National Institute of Standards and Technology. In 2008, ENECO filed for Chapter 11 Bankruptcy, and no further development appears to have occurred since 2008.

\subsubsection{Thermo-Photovoltaic Generator}

Thermo-photovoltaic (TPV) generators convert radiant energy into electricity. These systems involve a heat source, an emitter, a radiation filter, and a PV cell. As the emitter is heated, it emits electromagnetic radiation. The PV cell converts this radiation to electrical energy. The filter is used to pass radiation at wavelengths that match the PV cell, while reflecting remaining energy back to the emitter. A number of materials are being considered for use as an emitter. These materials must have a high melting point, high thermal conductivity, high emissivity, high corrosion resistance, resistance to thermal shock, and be capable of being formed and machined into the required configurations. TPV systems could potentially enable new methods for waste heat recovery. A small number of prototype systems have been built for small burner applications and in a helicopter gas turbine (DOE, 2008).

\subsubsection{Stirling Engine}

Colorado-based Cool Energy, Inc. (CEI) has developed prototypes of a low-temperature Stirling engine that generates electricity from low- to medium- temperature $\left(210^{\circ} \mathrm{F}\right.$ to $480^{\circ} \mathrm{F}$ ) heat sources, including solar thermal, geothermal and waste heat. For now, the main application is a solar thermal system for distributed residential heating and power. However, CEI plans to develop larger capacity Stirling engines to capture low temperature waste heat from sources such as fuel cells, microturbines or diesel engines.

In 2013, the U.S. Department of Energy awarded a $\$ 1$ million grant to CEI to support research and development on a $20 \mathrm{~kW}$ waste heat Stirling engine generator. The grant is supporting CEl's research and testing of its GeoHeart Engine, a $20 \mathrm{~kW}$ engine that will generate power from heat in co-produced liquids at oil and gas wells. 


\subsubsection{Steam Engine}

The steam engine is a mature technology with well understood cost and performance characteristics. Some vendors, such as Practical Steam, have been exploring niche applications for this established technology in WHP applications. The Practical Steam product (see Figure 9) is based on conventional engine blocks converted to steam engines for relatively small power output applications. Practical Steam has just entered that market, and has installed one $100 \mathrm{~kW}$ engine in a district heating plant in Seattle, Washington.

Figure 9. Steam Engine

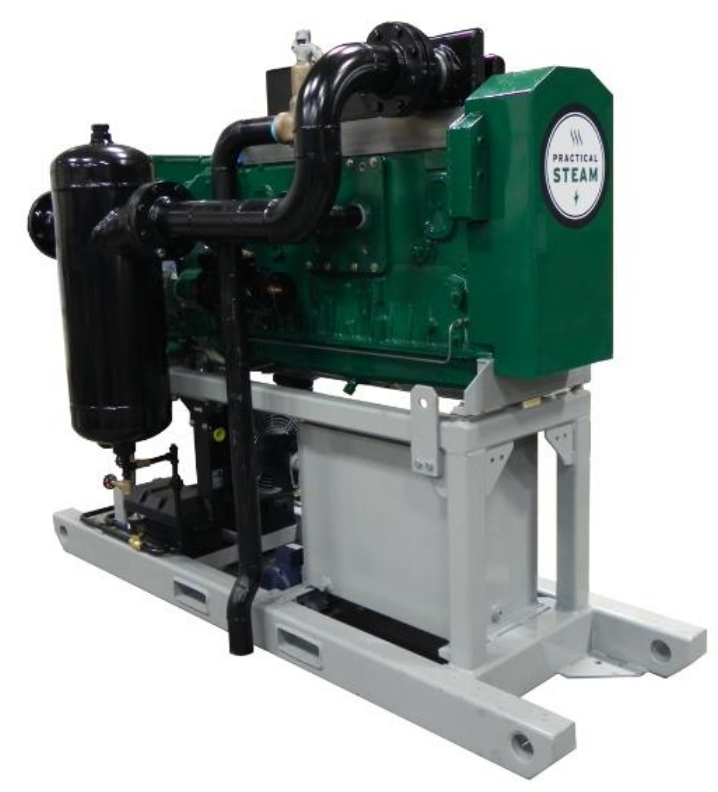

Source: Practical Steam, www.practicalsteam.com

\subsection{Costs}

ICF reviewed in-house data, published literature, and held discussions with industry stakeholders to develop cost estimates for commercially available SRC and ORC systems. These two technologies account for nearly all WHP systems currently installed, and are expected to be the dominant technologies that will be installed for the next several years. Other types of WHP systems, including emerging technologies, have not yet matured and are therefore not included in this cost analysis.

The results of ICF's cost analysis are shown in Table 5. As indicated, SRC capital costs range from $\$ 1,200$ to $\$ 3,000 / \mathrm{kW}$ as a function of capacity. ORC capital costs are 
higher, ranging from $\$ 2,100$ to $\$ 4,500 / \mathrm{kW}$. O\&M costs range from 0.5 to 1.3 cents $/ \mathrm{kWh}$ for SRC, to 1-2 cents/kWh for ORC.

Table 5. Waste Heat to Power Costs

\begin{tabular}{|c|c|c|c|c|c|c|}
\hline \multirow{2}{*}{ Technology } & \multirow{2}{*}{$\begin{array}{c}\text { Cost } \\
\text { Characteristic }\end{array}$} & \multicolumn{5}{|c|}{ Electric Capacity for WHP Technology } \\
\cline { 3 - 7 } & $50-500 \mathrm{~kW}$ & $500-1,000 \mathrm{~kW}$ & $1-5 \mathrm{MW}$ & $5-20 \mathrm{MW}$ & $>20 \mathrm{MW}$ \\
\hline $\begin{array}{c}\text { Steam } \\
\text { Rankine } \\
\text { Cycle }\end{array}$ & $\begin{array}{c}\text { Installed Capital } \\
\text { Cost, } \$ / \mathrm{kW}\end{array}$ & $\$ 3,000$ & $\$ 2,500$ & $\$ 1,800$ & $\$ 1,500$ & $\$ 1,200$ \\
\cline { 2 - 7 } & $\begin{array}{c}\text { O\&M Costs, } \\
\$ / \mathrm{kWh}\end{array}$ & $\$ 0.013$ & $\$ 0.009$ & $\$ 0.008$ & $\$ 0.006$ & $\$ 0.005$ \\
\hline \multirow{2}{*}{$\begin{array}{c}\text { Organic } \\
\text { Rankine } \\
\text { Cycle }\end{array}$} & $\begin{array}{c}\text { Installed Capital } \\
\text { Cost, } \$ / \mathrm{kW}\end{array}$ & $\$ 4,500$ & $\$ 4,000$ & $\$ 3,000$ & $\$ 2,500$ & $\$ 2,100$ \\
\cline { 2 - 7 } & $\begin{array}{c}\text { O\&M Costs, } \\
\$ / \mathrm{kWh}\end{array}$ & $\$ 0.020$ & $\$ 0.015$ & $\$ 0.013$ & $\$ 0.012$ & $\$ 0.010$ \\
\hline
\end{tabular}

Source: ICF analysis based on equipment manufacturer input.

The installed capital costs shown in Table $\mathbf{5}$ are based predominantly on information obtained through conversations with equipment suppliers. These costs likely do not contain contingency for site specific characteristics that can significantly increase costs for actual installations. While published information on actual installed costs for WHP projects is limited, one recent report for the cement industry suggests that costs could be significantly higher than those shown in Table 5 . This report suggests that the installed capital cost for a 2 MW WHP plant in the cement industry could be as high as $\$ 7,000 / \mathrm{kW}^{12}$

12 See IFC, 2014, pages 19-20. 


\section{Market Sectors}

The analysis of WHP potential begins with quantifying the amount of waste heat available. There are two reports that have provided this information. A 2004 ORNL study presented an inventory of waste heat from manufacturing establishments (NAICS 31-33). ${ }^{13}$ Another report, a 2008 U.S. DOE study, presented an inventory of waste heat for selected manufacturing sources only. ${ }^{14}$ Using these two reports, an inventory of waste heat sources was developed for this study. A more detailed discussion of how the final estimates of waste heat were developed is presented in Appendix C.

Figure 10 shows the waste heat inventory by industry (reference temperature of $120^{\circ} \mathrm{F}$ ). The figure shows that the largest waste heat source is the petroleum refining industry, followed by chemical, primary metals, nonmetallic minerals, fabricated metals and paper industries. Figure 10 also shows the temperature ranges of the waste heat for each industry. It is observed that the temperature ranges of waste heat differ substantially across the different industries. For example, the petroleum refining sector's waste heat is mainly within the 450 to $1,200^{\circ} \mathrm{F}$, while for the chemical industry, it is mainly less than $300^{\circ} \mathrm{F}$.

Key WHP opportunities include the five industries shown in Figure $\mathbf{1 0}$ as well as select identified opportunities in other areas. As indicated, the petroleum and coal products (NAICS 324) and chemical manufacturing sectors (NAICS 325) are the two dominant sectors based on three-digit NAICS codes.

${ }^{13}$ ORNL 2004.

14 DOE 2008. 


\section{Figure 10. Manufacturing Sector Waste Heat Inventory by Industry and Temperature Range (reference temperature at $120^{\circ} \mathrm{F}$ )}

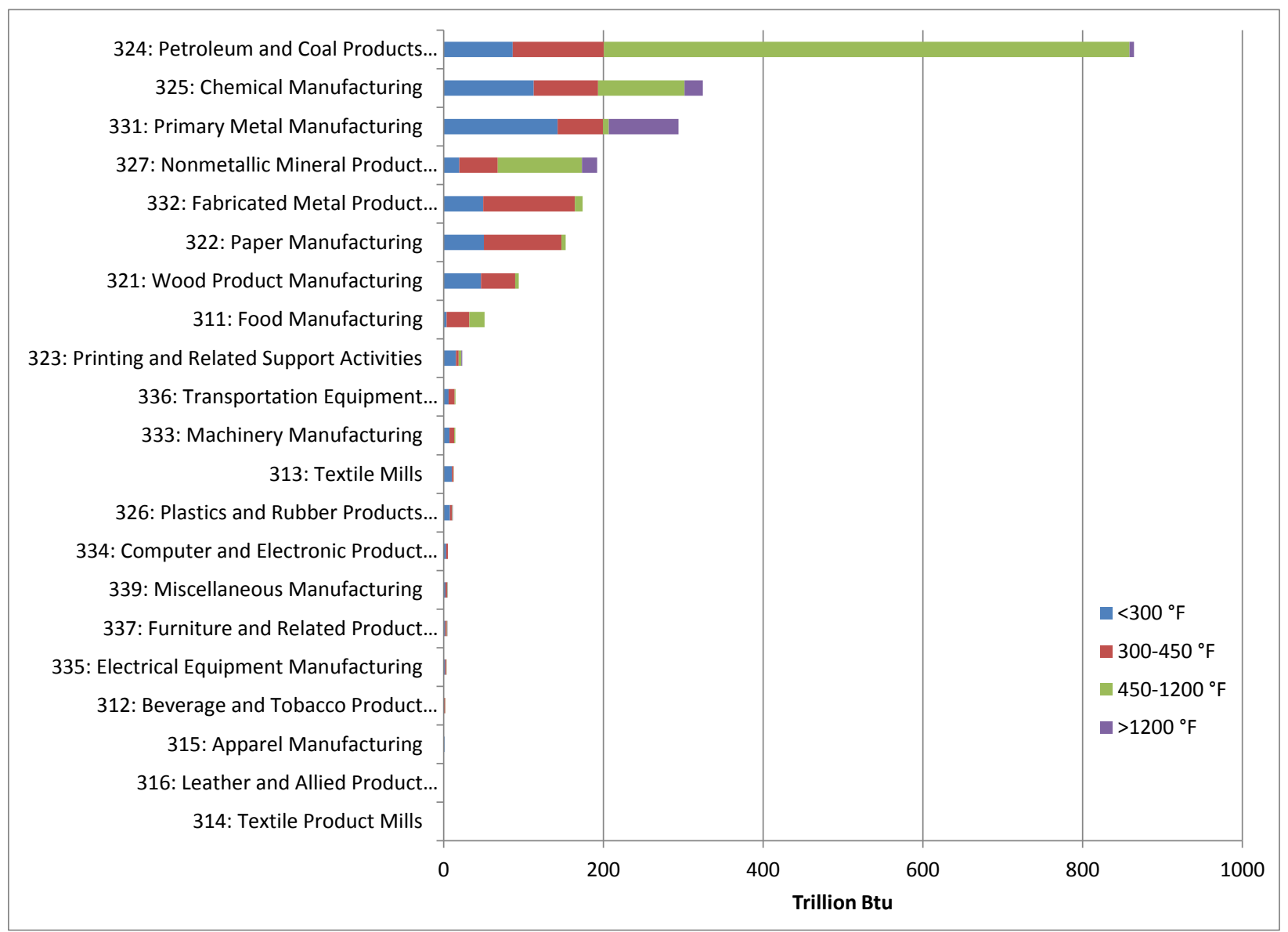

\subsection{NAICS 324: Petroleum and Coal Products}

Petroleum and coal product manufacturing, particularly petroleum refining, represents the largest energy consuming industrial group in the U.S. and includes the production of refined end-use products, such as gasoline, kerosene, and liquefied petroleum gas (LPG), as well as the production of feedstocks used in other industries, such as chemicals, rubber, and plastics manufacturing. Basic processes used in petroleum refineries include distillation processes (fractionation), thermal cracking processes, catalytic processes, and treatment processes. Although these processes use large amounts of energy, modern refineries capture and use waste heat for heating other processes, resulting in integrated heat recovery systems for process use.

Some exhaust streams at refineries contain high-quality waste heat that could be recovered for power production. An example is the exhaust from petroleum coke 
calciners. In this process, petroleum coke is heated to $2,400{ }^{\circ} \mathrm{F}$, and energy from the hot exhaust is recovered. One example is the heat recovery boiler/steam turbine WHP project at a petroleum coke plant in Texas. Port Arthur Steam Energy (PASE) recovers energy from the $2,000{ }^{\circ} \mathrm{F}$ exhaust from three petroleum- coke calcining kilns and produces $450,000 \mathrm{lb} / \mathrm{hr}$ of steam for process use at an adjacent refinery plus $5 \mathrm{MW}$ of power. ${ }^{15}$

\subsection{NAICS 325: Chemical Manufacturing}

The chemical industry is the second largest consumer of energy in the industrial sector, producing 70,000 different products (DOE, 2000). Many of the processes used to produce these products result in significant amounts of waste heat that has the potential to be converted to power. Major sectors in the chemical industry that have the potential for WHP applications include petrochemicals, industrial gases, alkalies and chlorine, cyclic crudes and intermediates (e.g., ethylene, propylene, and benzene/toluene/xylene), plastic materials, synthetic rubber, synthetic organic fibers, and agricultural chemicals (fertilizers and pesticides).

The Mosaic Fertilizer plant in Bartow, Florida, for example, produces sulfuric acid as an intermediate product, which is then used with other feedstock chemicals to manufacture a variety of dry fertilizer products. The sulfuric acid plant generates superheated steam at pressures in the range of 150 to 600 psig (the sulfuric acid process is exothermic). The site has $70 \mathrm{MW}$ of WHP capacity and exports about 40 percent of the electricity through the local utility grid to five nearby Mosaic plants.

\subsection{NAICS 327: Non-Metallic Mineral Products}

The non-metallic mineral products industries, which include cement manufacturing, glass and glass products manufacturing, clay tile and brick material manufacturing, are large consumers of energy with a strong potential for use of WHP for power production.

Similar to chemical manufacturing, there are numerous processes for which WHP could provide benefit. The glass industry uses raw material melting furnaces, annealing ovens, and tempering furnaces, all operated at high temperatures so exhaust heat may be available for power generation. Clay building products are fired in high-temperature kilns. Clay firing employs tunnel kilns and periodic kilns, depending on the product being produced. Periodic kilns do not represent a good opportunity for heat recovery for power due to their intermittent operation, but tunnel kilns are steadier in output and could provide an economic application. The following sections describe more specific WHP opportunities within non-metallic mineral products.

15 EPA, 2012. 


\section{NAICS 327310: Cement}

The cement industry uses large rotary kilns operated at temperatures close to $2,000^{\circ} \mathrm{F}$ to produce clinker. More generically, this is a calcining process, also used to produce gypsum, alumina, soda ash, lime, and kaolin clay. These processes produce high temperature exhaust that can be utilized for WHP systems. ${ }^{16}$

\section{NAICS 327410: $\quad$ Lime}

Lime production is based on another calcining process that occurs in large rotary kilns similar to the cement industry. For example, Graymont, Ltd. installed a WHP power plant on a 1,050 ton/day rotary lime kiln in Pleasant Gap, PA in 2008 (see Figure 11). This lime kiln incorporates a highly efficient emissions scrubbing system along with 5 $\mathrm{MW}$ of power generation from a waste heat recovery system. This waste heat recovery and power generation system is the only one of its kind installed on a lime kiln in North America.

Figure 11. WHP from Lime Production

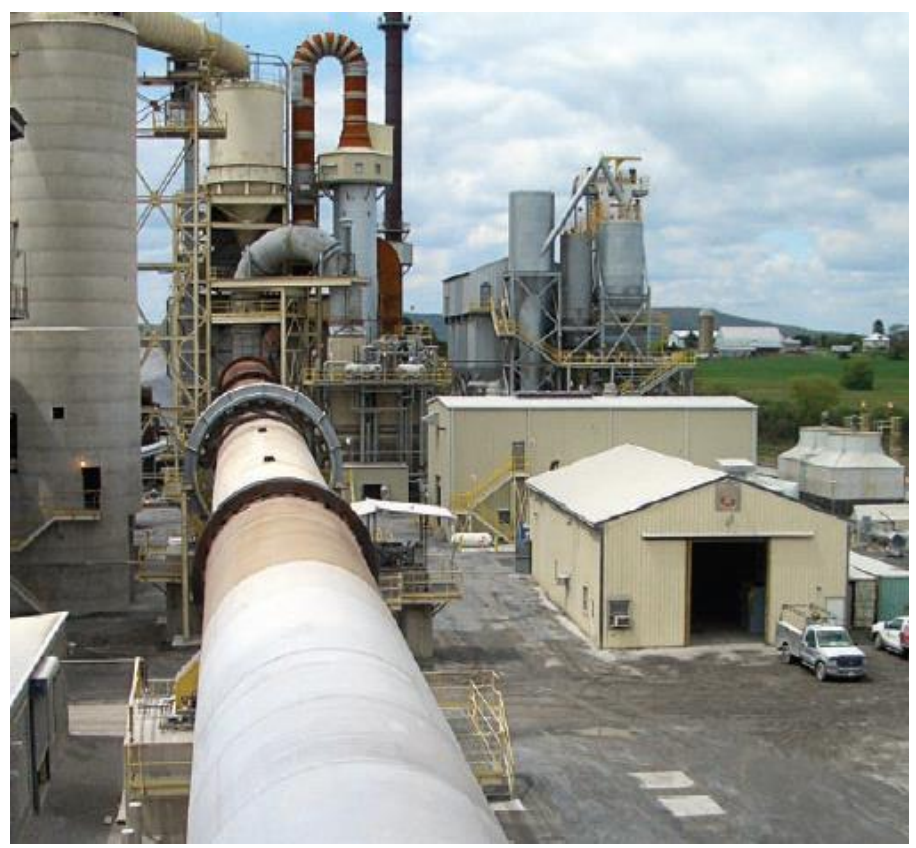

Source: Graymont, 2009

\footnotetext{
${ }^{16}$ The amount of waste heat that could be recovered depends on the kiln system, production throughput, moisture content of the raw material, and heat requirements for drying.
} 


\section{NAICS 327211, 327212: Flat Glass and Container Glass}

The glass industry uses raw material melting furnaces, annealing ovens, and tempering furnaces, all operated at high temperatures. Modern glass factories use regenerative furnaces to maintain high energy efficiency, which may limit the amount of waste heat.

\subsection{NAICS 33: Primary Metal Manufacturing}

Primary metals manufacturing contains a large number of high temperature processes from which waste heat can be recovered. This section describes opportunities in primary iron and steel production, primary aluminum production, metal casting, and silicon/ferro-silicon production.

\section{NAICS 331111: Iron and Steel Mills}

Steel mills have a number of high temperature heat recovery opportunities. In integrated mills, waste heat can be recovered from coke ovens, blast furnaces for iron production, and basic oxygen furnaces for steel production. There are also opportunities to recover waste heat from the electric arc furnace, mostly in steel "minimills", that produce steel largely from recycled scrap. About 46 percent of steel production in the U.S. now comes from these mini-mills.

\section{Coke Oven}

Coke is carbonized coal and is an essential part of blast furnace operations to reduce iron ore and increase productivity of the iron-making process. However, coke must be produced before it can be added to the blast furnace, typically through the byproduct process. In this process, chemical byproducts (tar, ammonia, and light oils) in the coke oven gas are recovered, while the remaining combustible coke oven gas is cleaned and recycled within the steel plant. Waste heat could be recovered from the hot gas exiting the coke ovens at 1200-1800 ${ }^{\circ} \mathrm{F}$; however, these gases are full of tars and contaminants that would make heat recovery difficult. Some steel mills in Japan recover about a third of the energy contained in the hot coke oven gas keeping the exit temperature above the condensation point for the tars - about $840^{\circ} \mathrm{F}$. Another source of waste heat in coke ovens is the waste gases exiting the flue at $400{ }^{\circ} \mathrm{F}$ from combustion of the recycled and cleaned coke oven gas (DOE, 2008). Given the medium-range, useful waste heat available, coke ovens may be appropriate applications for ORC systems.

\section{Blast Furnace}

In a steel plant, the blast furnace converts iron ore into pig iron, which is an intermediate product eventually used to create steel. Older blast furnaces have high exhaust temperatures around $900{ }^{\circ} \mathrm{F}$ while new furnaces have been designed for more efficient 
heat transfer. As a result, exhaust gases are in the low temperature range, meaning SRC systems may not be viable for newer furnaces. While there are $910 \mathrm{MW}$ of existing CHP capacity using blast furnace gas as the input fuel, these systems are not included in the waste heat recovery potential because the power is generated directly from the gas fuel and not from the exhaust gas. However, in 2012, Primary Energy upgraded their Northlake waste heat recovery project at ArcelorMittal in East Chicago, IN. By using the gas originally flared, Northlake increased generation from a total capacity of $75 \mathrm{MW}$ in 1996 to $90 \mathrm{MW}$ in 2013. ${ }^{17}$

\section{Basic Oxygen Furnace}

Basic oxygen furnaces (BOF) use oxygen to refine pig iron into steel. The heat required for the refining and melting process is provided by an exothermic reaction within the furnace. For U.S. production, the very high temperature off-gases from the BOF amount to $27 \mathrm{TBtu}$ of waste heat per year. BOF gas has a high concentration of carbon monoxide, and like coke oven gas and blast furnace gas, BOF gases offer opportunities for recovery of chemical energy (as fuel) and sensible heat. Heat recovery is more costly and maintenance intensive due to contaminants in the exhaust stream.

\section{Electric Arc Furnace}

About 46 percent of total U.S. steel production comes from scrap-based mini-mills that use an electric arc furnace (EAF) to melt and refine scrap into new steel. Waste heat exits the EAF at about 2,200 ${ }^{\circ} \mathrm{F}$. The heat can be captured in a waste heat recovery steam boiler for conversion to power, use in district heating operations, or in other onsite needs. The most common form of heat recovery in EAF operation is scrap preheating.

\section{NAICS 331312: $\quad$ Primary Aluminum Production}

In the aluminum industry, there is energy recovery potential from the exhaust of Hall Heroult ${ }^{18}$ cells and secondary melting. In addition to the small exhaust losses from primary aluminum production in Hall Heroult cells, there is also recoverable energy from sidewall losses through conduction, convection, and radiation. Presently, there is no commercial way to reduce or recover these sidewall losses as they are necessary to maintain a frozen crust along the walls to minimize corrosion of the refractory. In the future, it may be possible to design thermoelectric power production into the sidewalls that can produce power and control sidewall heat transfer.

\footnotetext{
17 http://www.heatispower.org/hip-statement-to-house-committee-on-energy-and-commerce/

18 The Hall-Heroult process is the major industrial process for the production of elemental aluminum. It involves dissolving alumina in molten cryolite, and electrolyzing the molten salt bath, typically in a purpose-built cell.
} 


\section{NAICS 331112: $\quad$ Silicon/Ferrosilicon Production}

Silicon and ferrosilicon alloys are produced in electric arc melters and also offer opportunities for WHP. Batch melters have exhaust gas temperatures that range from 625 to $2,550^{\circ} \mathrm{F}$ during the cycle, making heat recovery difficult to plan due to the wide temperature swings. Continuous charge furnaces have much lower temperature swings with an average exhaust temperature of about $1,400{ }^{\circ} \mathrm{F}$.

\section{NAICS 3315: Ferrous and Nonferrous Foundries}

Metal foundries contain a variety of waste heat sources, such as melting furnace exhaust, ladle pre-heating, core baking, pouring, cast metal cooling, heat treating, and quenching. The highest temperature waste heat sources are off-gases from melting and heat-treating furnaces. The exhaust from the heat-treating furnaces is the cleanest steady temperature source, free of particulates and corrosives. Pouring and core baking are also high-temperature waste heat sources, but economic utilization of these sources is difficult because of the intermittent nature of waste heat generation or the relatively small streams.

Reverberatory furnaces are the most commonly used melting furnaces among high volume aluminum foundries and account for melting 90 percent of aluminum produced in the United States. Aluminum reverberatory furnaces are only 30-35 percent efficient and have exhaust temperatures of about 2,000-2,400 ${ }^{\circ} \mathrm{F}$. Due to the high exhaust heat temperature SRC systems are more viable for these furnaces. Stack melters, while more efficient (40-45 percent), are less commonly used due to higher maintenance costs and more restrictive requirements on charging.

Melting furnaces for iron casting include induction furnaces, electric arc furnaces, and cupola furnaces. Cupolas make up about 60 percent of the total melting capacity in the industry (DOE, 2008). The efficiency of cupola furnaces has improved substantially in recent years ranging from $5 \mathrm{MMBtu} / \mathrm{ton}$ for older models to $3.4 \mathrm{MMBtu} /$ ton for newer designs. Older cupolas are about 50 percent efficient with exhaust gas temperatures ranging from $1,500-1,800^{\circ} \mathrm{F}$, allowing the use of SRC systems for WHP. Newer furnaces employing recuperators have exhaust temperatures of $400^{\circ} \mathrm{F}$ (DOE, 2008) so ORC or lower temperature systems must be applied. Induction heating and melting furnaces have water cooling circuits that produce low temperature waste heat. These low temperatures, below $150^{\circ} \mathrm{F}$, are not attractive for power generation using commercial technology; however, advanced systems might be applied in the future.

\section{NAICS 332: Fabricated Metals}

Fabricated metals processes generating waste heat include metal pre-heating, heat treatment, cleaning, drying, and furnace heating. Based on the UTRC waste heat 
analysis (ORNL, 2004), the exhaust temperature range for fabricated metals processing is $300-700^{\circ} \mathrm{F}$.

\subsection{Other Market Sectors for WHP}

\section{Natural Gas Compressor Stations}

Compressor stations are suitable for waste heat to electricity conversion. Waste heat is available in the form of exhaust from the internal combustion engines or gas turbines that drive the compressors. In most cases there is no thermal requirement at compressor stations; therefore there is a strong case for converting the waste heat to electricity. Currently, there are 12 ORC power generation systems installed at natural gas compressor stations in the U.S. The 12 US systems have a total electric capacity of $64 \mathrm{MW}$ using the exhaust heat from $247,000 \mathrm{hp}$ of gas turbine driven compressors. ${ }^{19}$

\section{Landfill Gas}

There are two types of opportunities for WHP at landfills. At those facilities that use engines or turbines to produce power, there is an opportunity for additional power generation using ORC systems to generate power from the exhaust gases. Those facilities that do not have energy recovery could install an ORC WHP system to recover the heat associated with gas flaring or use the byproduct fuel in a reciprocating engine to generate electricity.

\section{Flare Gas in Oil and Gas Production}

In oil and gas production, methane-containing gases are vented and flared throughout the production cycle. Flares are used for both background and upset (emergency) use. This methane can be recovered and used for local power production.

Adding an ORC system to a flare to produce electricity is an alternative to the option of removing the flare and using the previously flared fuel in an internal combustion engine or microturbine. The internal combustion engine or microturbine option would produce more power per unit of heat input and would generally be less costly. However, where fuel quality is variable and contains contaminants, the ORC WHP option may be technically and economically preferable.

\section{Steam Pressure Reduction}

A market niche is developing for small back pressure steam turbine power systems to be installed in parallel with steam pressure reducing valves (PRV) for applications where steam is produced or delivered at a higher pressure than needed. This situation

${ }_{19}$ ICF Internal Estimates, based on data from pipeline compressor companies. 
typically exists for commercial or industrial facilities that are connected to a steam district heating system or for industrial sites that have a centralized high pressure steam production and distribution system with multiple steam using applications, many of them at low pressure.

A customer of a district heating system may receive steam at 200 psig and require only 15 psig for an absorption chiller. A PRV typically is used to reduce pressure in this case. The PRV does not recover energy or work from the pressure reduction. A back pressure steam turbine, on the other hand, can be used in place of a PRV to reduce pressure and generate power. This power generation is not "free" energy, because the work performed by the turbine removes energy from the steam flow. The efficiency of this power generation, however, is very high - approaching the original boiler efficiency. With an 80 percent efficient boiler, power can be generated with a BPST at a heat rate of under 4,500 Btu/kWh (HHV). 


\section{Existing Installations}

The installed base of WHP was developed by first examining the CHP Installation Database that ICF maintains for Oakridge National Laboratory (ICF, 2013). This database contains both CHP topping cycle and CHP bottoming cycle projects. All installations in this database labeled as bottoming cycle were pulled out and identified as WHP installations. Next, ICF researched non-CHP applications for WHP. This research identified several mechanical drive applications, mostly natural gas pipeline compressor stations, with WHP equipment, as well as several WHP systems using waste heat from exothermic reactions.

In total, ICF identified 96 existing WHP systems (CHP and non-CHP), totaling $766 \mathrm{MW}$ of power generation capacity. Figure 12 shows a breakdown of existing industrial WHP capacity by sector. Existing systems are concentrated in the chemical, primary metals, petroleum refining, and pipeline transportation sectors. The chemical industry has the largest number of WHP facilities and the largest WHP capacity, with 19 installations totaling almost $270 \mathrm{MW}$. The primary metals industry has the second largest WHP capacity, with three large installations totaling $217 \mathrm{MW}$. The petroleum refining industry has five WHP installations with a total of $118 \mathrm{MW}$. The 12 WHP projects in the pipeline transportation sector are all in compressor stations, and have a total capacity of $64 \mathrm{MW}$. These four sectors account for $672 \mathrm{MW}$, or 87 percent of total WHP capacity.

Figure 12. Existing Waste Heat to Power Projects by Sector

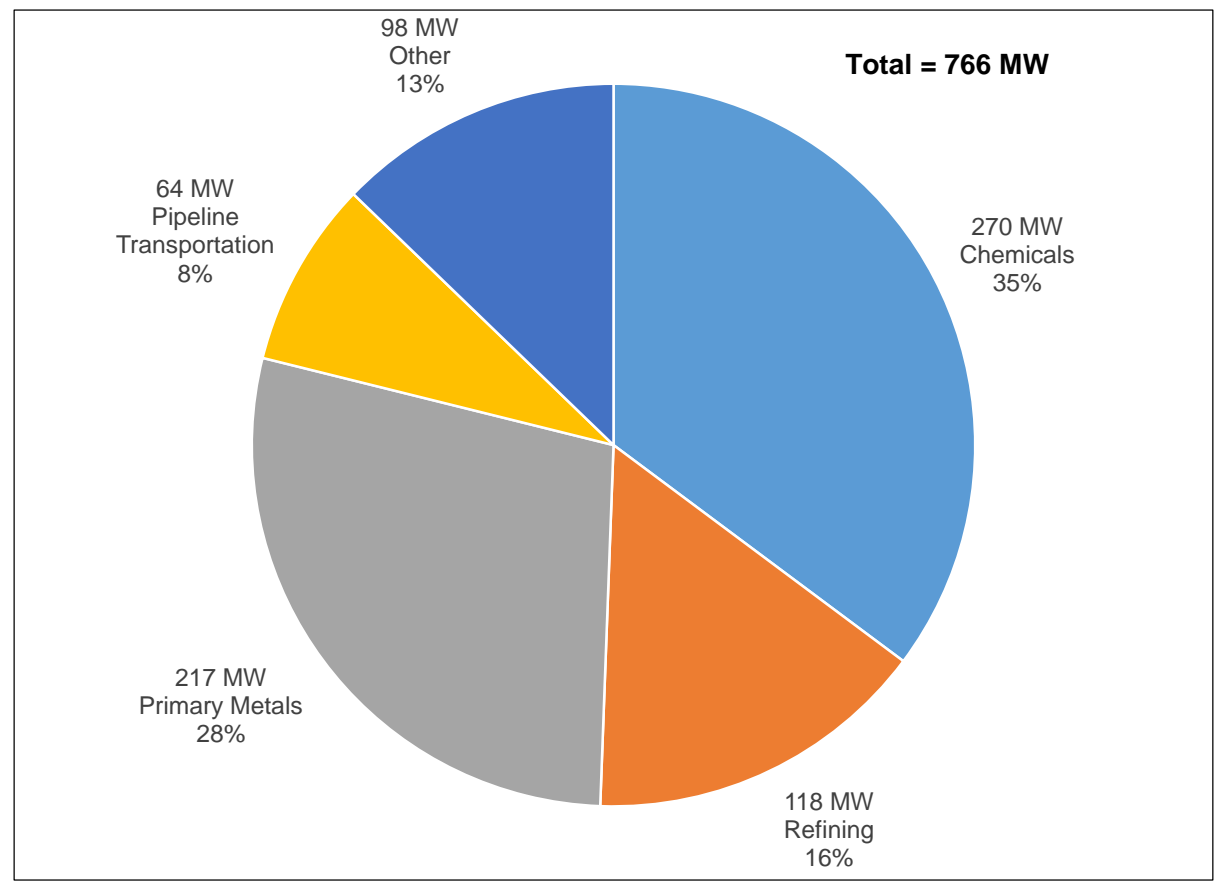


WHP sites are located in 40 states (see Table 6), with Indiana having the largest total capacity at $185 \mathrm{MW}$, which comes from two steel plants. In terms of the number of installations, Pennsylvania has the largest number (9), followed by Minnesota (7), Massachusetts (6), and Florida (4). Florida is the state with the second largest total WHP capacity at 183 , mainly in phosphorous fertilizer production. Ohio has the third largest WHP capacity at $101 \mathrm{MW}$, with petroleum refining accounting for most of the capacity.

Table 6. Existing Waste Heat to Power Projects by State

\begin{tabular}{|l|c|c|c|}
\hline State & $\begin{array}{c}\text { No. of } \\
\text { Facilities }\end{array}$ & $\begin{array}{c}\text { Capacity } \\
\text { (MW) }\end{array}$ & $\begin{array}{c}\text { Share of } \\
\text { Total } \\
\text { Capacity }\end{array}$ \\
\hline Indiana & 2 & 185 & $24.15 \%$ \\
\hline Florida & 4 & 183 & $23.90 \%$ \\
\hline Ohio & 3 & 101 & $13.20 \%$ \\
\hline Louisiana & 4 & 55 & $7.23 \%$ \\
\hline Michigan & 3 & 50 & $6.46 \%$ \\
\hline Utah & 1 & 32 & $4.18 \%$ \\
\hline North Dakota & 4 & 22 & $2.87 \%$ \\
\hline California & 4 & 18 & $2.38 \%$ \\
\hline South Dakota & 3 & 17 & $2.15 \%$ \\
\hline Minnesota & 7 & 16 & $2.08 \%$ \\
\hline Idaho & 1 & 16 & $2.08 \%$ \\
\hline Texas & 2 & 14 & $1.84 \%$ \\
\hline Colorado & 3 & 7 & $0.85 \%$ \\
\hline Pennsylvania & 9 & 6 & $0.83 \%$ \\
\hline Montana & 2 & 6 & $0.78 \%$ \\
\hline Nevada & 1 & 6 & $0.72 \%$ \\
\hline Tennessee & 3 & 4 & $0.57 \%$ \\
\hline DC & 1 & 4 & $0.52 \%$ \\
\hline Kansas & 1 & 4 & $0.52 \%$ \\
\hline Illinois & 1 & 3 & $0.39 \%$ \\
\hline New York & 4 & 3 & $0.33 \%$ \\
\hline
\end{tabular}

\begin{tabular}{|l|c|c|c|}
\hline State & $\begin{array}{c}\text { No. of } \\
\text { Facilities }\end{array}$ & $\begin{array}{c}\text { Capacity } \\
\text { (MW) }\end{array}$ & $\begin{array}{c}\text { Share of } \\
\text { Total } \\
\text { Capacity }\end{array}$ \\
\hline Massachusetts & 6 & 2 & $0.31 \%$ \\
\hline Nebraska & 1 & 2 & $0.26 \%$ \\
\hline Wisconsin & 3 & 1.4 & $0.18 \%$ \\
\hline South Carolina & 1 & 1.4 & $0.18 \%$ \\
\hline Kentucky & 2 & 1.3 & $0.17 \%$ \\
\hline Vermont & 3 & 1.2 & $0.16 \%$ \\
\hline North Carolina & 2 & 1 & $0.13 \%$ \\
\hline Maryland & 1 & 0.9 & $0.12 \%$ \\
\hline Alabama & 1 & 0.8 & $0.10 \%$ \\
\hline Mississippi & 2 & 0.8 & $0.10 \%$ \\
\hline Alaska & 1 & 0.6 & $0.08 \%$ \\
\hline Maine & 1 & 0.6 & $0.08 \%$ \\
\hline Wyoming & 1 & 0.4 & $0.05 \%$ \\
\hline lowa & 2 & 0.3 & $0.04 \%$ \\
\hline Georgia & 1 & 0.3 & $0.04 \%$ \\
\hline Virginia & 2 & 0.2 & $0.02 \%$ \\
\hline Missouri & 1 & 0.1 & $0.01 \%$ \\
\hline Rhode Island & 1 & 0.1 & $0.01 \%$ \\
\hline Oklahoma & 1 & 0.1 & $0.01 \%$ \\
\hline Total & 96 & 766 & $100 \%$ \\
\hline
\end{tabular}




\section{Technical Potential (all waste heat stream temperatures)}

This chapter describes the technical potential for generating electricity from gaseous waste heat streams in the manufacturing sector. The technical potential described in this chapter includes all waste heat stream temperatures, including low temperature $\left(<450^{\circ} \mathrm{F}\right)$ waste heat sources. The approach used for the technical potential estimate described in this chapter is based on a "top-down" analysis that starts with waste heat inventory estimates. Two sources for waste heat inventory estimates were evaluated an ORNL $2004^{20}$ report and a DOE 2008 report. ${ }^{21}$

The waste heat inventory results from the ORNL 2004 report are shown in Table 7. These results are based on an analysis of National Emissions Inventory (NEI) data, and show that the waste heat inventory in the manufacturing sector is estimated at slightly over 3 quads $(3,086 \mathrm{TBtu} / \mathrm{yr})$. The reference temperature for this estimate is $60^{\circ} \mathrm{F}$, and the estimate covers temperatures up to $1,800^{\circ} \mathrm{F}$.

The DOE 2008 results are focused on a subset of the manufacturing sector, and include details for temperatures exceeding 2,700 ${ }^{\circ} \mathrm{F}$. Data from the DOE 2008 report were used to adjust the ORNL 2004 waste heat inventory, and the adjusted results are shown in Table 7. As indicated, the adjusted results increased by about 7 percent compared to the ORNL 2004 waste heat inventory results (increase from 3,086 TBtu/yr to 3,306 TBtu/yr). Additional details on how the ORNL 2004 and DOE 2008 waste heat inventories were combined are provided in Appendix C.

The next step in the analysis was to determine a reasonable reference temperature for converting waste heat to electricity. A reference temperature of $60^{\circ} \mathrm{F}$ represents an upper limit on the amount of energy than can be extracted from waste heat streams. Both the ORNL 2004 and DOE 2008 reports use a reference temperature of $300{ }^{\circ} \mathrm{F}$ to estimate the available energy from higher quality waste heat streams. For WHP applications, a reference temperature of $300^{\circ} \mathrm{F}$ is viewed as conservative given recent technology advancements that allow some WHP technologies, such as ORC machines, to operate with waste heat streams at $200^{\circ} \mathrm{F}$ or lower. For the purposes of this study, a reference temperature of $120^{\circ} \mathrm{F}$ was selected, which is midway between an ambient reference temperature of $60^{\circ} \mathrm{F}$ and an ORC machine that utilizes $180^{\circ} \mathrm{F}$ waste heat. $\mathrm{A}$ reference temperature of $120^{\circ} \mathrm{F}$ excludes waste heat energy below $120^{\circ} \mathrm{F}$, but still includes a significant fraction of low temperature $\left(<450^{\circ} \mathrm{F}\right)$ waste heat energy. At a

\footnotetext{
20 ORNL 2004, An Inventory of Industrial Waste Heat and Opportunities for Thermally Activated Technologies, Prepared by United Technologies Research Center for Oak Ridge National Laboratory.

${ }^{21}$ DOE 2008, Waste Heat Recovery: Technology and Opportunities in U.S. Industry, Prepared by BCS for the U.S. Department of Energy.
} 
$120^{\circ} \mathrm{F}$ reference temperature, the total waste heat inventory is $2,245 \mathrm{TBtu} / \mathrm{yr}$ (see

Table 7).

Table 7. Technical Potential for Electricity Generation

\begin{tabular}{|c|c|c|c|c|c|c|c|c|}
\hline \multicolumn{2}{|c|}{ Waste Heat Temp (F) } & \multicolumn{3}{|c|}{ Energy Content (TBtu / yr) } & \multicolumn{2}{|c|}{ WHP Efficiency } & \multicolumn{2}{|c|}{$\begin{array}{l}\text { Technical } \\
\text { Potential }\end{array}$} \\
\hline \multirow[b]{2}{*}{ Range } & \multirow[b]{2}{*}{ Avg } & \multicolumn{2}{|c|}{ Ref Temp $=60 \mathrm{~F}$} & \multirow{2}{*}{$\begin{array}{c}\text { Ref } \\
\text { Temp = } \\
120 \mathrm{~F}(1)\end{array}$} & \multirow[b]{2}{*}{ Carnot } & \multirow[b]{2}{*}{$\begin{array}{l}\text { Practical } \\
\text { System (2) }\end{array}$} & \multirow[b]{2}{*}{$\begin{array}{c}\text { (TBtu / } \\
\mathrm{yr})\end{array}$} & \multirow[b]{2}{*}{$\begin{array}{c}(\mathrm{MW}) \\
(3)\end{array}$} \\
\hline & & $\begin{array}{c}\text { From } \\
\text { ORNL 2004 }\end{array}$ & $\begin{array}{c}\text { With DOE } \\
2008 \\
\text { Adjustments }\end{array}$ & & & & & \\
\hline$<100$ & 60 & 201 & 201 & 0 & --- & --- & --- & --- \\
\hline $100-200$ & 150 & 685 & 685 & 228 & $12.0 \%$ & $4.0 \%$ & 9.1 & 445 \\
\hline $200-300$ & 250 & 499 & 499 & 341 & $24.4 \%$ & $8.1 \%$ & 27.7 & 1,354 \\
\hline $300-400$ & 350 & 507 & 507 & 402 & $33.7 \%$ & $11.2 \%$ & 45.1 & 2,204 \\
\hline $400-500$ & 450 & 249 & 249 & 210 & $41.0 \%$ & $13.7 \%$ & 28.7 & 1,403 \\
\hline $500-600$ & 550 & 447 & 447 & 392 & $46.8 \%$ & $15.6 \%$ & 61.2 & 2,987 \\
\hline $600-700$ & 650 & 53 & 117 & 105 & $51.6 \%$ & $17.2 \%$ & 18.0 & 882 \\
\hline $700-800$ & 750 & 13 & 13 & 12 & $55.6 \%$ & $18.5 \%$ & 2.3 & 111 \\
\hline $800-900$ & 850 & 58 & 103 & 95 & $59.0 \%$ & $19.7 \%$ & 18.7 & 915 \\
\hline $900-1000$ & 950 & 344 & 344 & 321 & $61.9 \%$ & $20.6 \%$ & 66.1 & 3,230 \\
\hline $1000-1100$ & 1,050 & 0 & 1 & 1 & $64.5 \%$ & $21.5 \%$ & 0.3 & 13 \\
\hline $1100-1200$ & 1,150 & 0 & 0 & 0 & $66.7 \%$ & $22.2 \%$ & 0.0 & 0 \\
\hline $1200-1300$ & 1,250 & 5 & 7 & 7 & $68.6 \%$ & $22.8 \%$ & 1.6 & 77 \\
\hline $1300-1400$ & 1,350 & 3 & 3 & 3 & $70.3 \%$ & $23.4 \%$ & 0.7 & 35 \\
\hline $1400-1500$ & 1,450 & 1 & 1 & 1 & $71.9 \%$ & $23.9 \%$ & 0.3 & 16 \\
\hline $1500-1600$ & 1,550 & 6 & 6 & 6 & $73.3 \%$ & $24.4 \%$ & 1.4 & 71 \\
\hline $1600-1700$ & 1,650 & 2 & 22 & 21 & $74.6 \%$ & $24.8 \%$ & 5.1 & 251 \\
\hline $1700-1800$ & 1,750 & 14 & 30 & 29 & $75.7 \%$ & $25.2 \%$ & 7.3 & 356 \\
\hline $1800-1900$ & 1,850 & --- & 8 & 7 & $76.8 \%$ & $25.6 \%$ & 1.9 & 93 \\
\hline $1900-2000$ & 1,950 & --- & 0 & 0 & $77.7 \%$ & $25.9 \%$ & 0.0 & 0 \\
\hline $2000-2100$ & 2,050 & --- & 0 & 0 & $78.6 \%$ & $26.2 \%$ & 0.0 & 0 \\
\hline $2100-2200$ & 2,150 & $\begin{array}{l}-- \\
\end{array}$ & 19 & 18 & $79.4 \%$ & $26.5 \%$ & 4.8 & 235 \\
\hline $2200-2300$ & 2,250 & --- & 6 & 6 & $80.2 \%$ & $26.7 \%$ & 1.5 & 74 \\
\hline $2300-2400$ & 2,350 & --- & 0 & 0 & $80.9 \%$ & $26.9 \%$ & 0.0 & 0 \\
\hline $2400-2500$ & 2,450 & --- & 8 & 7 & $81.6 \%$ & $27.2 \%$ & 2.0 & 98 \\
\hline $2500-2600$ & 2,550 & --- & 0 & 0 & $82.2 \%$ & $27.4 \%$ & 0.0 & 0 \\
\hline $2600-2700$ & 2,650 & --- & 4 & 4 & $82.7 \%$ & $27.6 \%$ & 1.1 & 56 \\
\hline$>2700$ & 2,750 & --- & 27 & 27 & $83.3 \%$ & $27.7 \%$ & 7.4 & 361 \\
\hline & & 3,086 & 3,306 & 2,245 & & & 312 & 15,265 \\
\hline
\end{tabular}

Notes: 1) The reference temperature adjustment is based on sensible heat only, and does not include latent heat.

2) Practical systems are assumed to operate at $1 / 3$ of the Carnot efficiency.

3) Industrial plants that generate waste heat streams are assumed to operate an average of 6,000 hrs/yr.

Electric power is calculated using this annual operating time. 
The Carnot efficiency described in Chapter 3 represents the maximum efficiency that can be achieved in converting waste heat to electricity. In practice, WHP technologies operate at efficiencies considerably lower than the Carnot limit. Based on discussions with equipment vendors ${ }^{22}$ and literature sources, ${ }^{23}$ WHP systems often operate at about $1 / 3$ of the Carnot efficiency. For the purposes of developing a technical potential estimate, the conversion efficiency for WHP technologies is assumed to be $1 / 3$ of the Carnot limit. These efficiency values are shown in Table 7.

The waste heat inventory values in Table 7 were multiplied by the expected efficiency performance to yield an estimated electricity production of $312 \mathrm{TBtu} / \mathrm{yr}$. This value represents about 14 percent of the total waste heat inventory of 2,245 TBtu/yr at a reference temperature of $120^{\circ} \mathrm{F}$. The annual electricity production was converted to electric power based on an assumption that industrial plants have an average annual operating time of $6,000 \mathrm{hrs} / \mathrm{yr}$. As indicated in Table 7, the estimated WHP technical potential is estimated to be slightly over $15 \mathrm{GW}(15,265 \mathrm{MW})$.

As part of the technical potential analysis, the waste heat inventory was analyzed by NAICS code and temperature range. These results are shown in Table 8. As this table shows, the largest waste heat source is the petroleum and coal products (which includes petroleum refining), followed by the chemical, primary metals, non-metallic minerals, fabricated metals, and paper industries. For temperatures above $450^{\circ} \mathrm{F}$, petroleum and coal products manufacturing dominates, followed by chemical manufacturing, nonmetallic mineral product manufacturing, and primary metal product manufacturing. At temperatures below $450^{\circ} \mathrm{F}$, petroleum and coal products manufacturing has a relatively large waste heat inventory, along with fabricated metal product manufacturing and paper manufacturing.

22 ICF discussed efficiencies with ElectraTherm and other hardware vendors. Efficiencies can vary significantly based on technology designs and site specific conditions. The 1/3 Carnot limit is not intended to reflect the efficiency for any particular type of WHP technology or any particular product. Rather, this efficiency is intended to represent an average efficiency for all WHP technologies across all waste heat stream temperatures.

${ }^{23}$ Turboden has an on-line calculator for ORC systems (http://www.turboden.eu/en/rankine/rankinecalculator.php). This calculator can be used to estimate system efficiencies based on site specific parameters. Based on a limited analysis, the Turboden calculator produced results consistent with an efficiency assumption of $1 / 3$ the Carnot limit. 
Table 8. Waste Heat Inventory by NAICS Code

$\left(120^{\circ} \mathrm{F}\right.$ reference temperature)

\begin{tabular}{|c|c|c|c|c|c|}
\hline \multirow{2}{*}{ Industry } & \multicolumn{5}{|c|}{ Energy Content (TBtu/yr) by Temperature Range (F) } \\
\hline & $<300$ & $300-450$ & $450-1200$ & $>1200$ & Total \\
\hline 311: Food Manufacturing & 3.7 & 28.3 & 19.2 & - & 51.3 \\
\hline $\begin{array}{l}\text { 312: Beverage and Tobacco Product } \\
\text { Manufacturing }\end{array}$ & 0.2 & 1.6 & 0.2 & - & 2.0 \\
\hline 313: Textile Mills & 10.3 & 1.9 & 0.4 & - & 12.6 \\
\hline 314: Textile Product Mills & 0.0 & - & - & - & 0.0 \\
\hline 315: Apparel Manufacturing & 1.1 & - & - & - & 1.1 \\
\hline 316: Leather and Allied Product Manufacturing & 0.0 & - & - & - & 0.0 \\
\hline 321: Wood Product Manufacturing & 46.8 & 42.8 & 4.4 & - & 94.0 \\
\hline 322: Paper Manufacturing & 50.3 & 97.0 & 5.3 & - & 152.6 \\
\hline 323: Printing and Related Support Activities & 15.5 & 3.2 & 3.4 & 1.1 & 23.2 \\
\hline $\begin{array}{l}\text { 324: Petroleum and Coal Products } \\
\text { Manufacturing }\end{array}$ & 86.4 & 114.2 & 658.1 & 5.6 & 864.3 \\
\hline 325: Chemical Manufacturing & 112.8 & 80.4 & 108.3 & 22.9 & 324.4 \\
\hline $\begin{array}{l}\text { 326: Plastics and Rubber Products } \\
\text { Manufacturing }\end{array}$ & 7.9 & 2.4 & 0.6 & 0.5 & 11.4 \\
\hline 327: Nonmetallic Mineral Product Manufacturing & 19.5 & 48.1 & 105.7 & 18.9 & 192.1 \\
\hline 331: Primary Metal Manufacturing & 142.7 & 56.8 & 7.2 & 87.2 & 293.9 \\
\hline 332: Fabricated Metal Product Manufacturing & 49.5 & 114.8 & 9.8 & - & 174.1 \\
\hline 333: Machinery Manufacturing & 7.4 & 5.7 & 1.3 & - & 14.4 \\
\hline $\begin{array}{l}\text { 334: Computer and Electronic Product } \\
\text { Manufacturing }\end{array}$ & 3.1 & 2.2 & - & - & 5.3 \\
\hline 335: Electrical Equipment Manufacturing & 2.0 & 1.4 & 0.3 & - & 3.6 \\
\hline 336: Transportation Equipment Manufacturing & 6.2 & 7.4 & 1.1 & - & 14.7 \\
\hline $\begin{array}{l}\text { 337: Furniture and Related Product } \\
\text { Manufacturing }\end{array}$ & 2.1 & 1.9 & 0.5 & 0.1 & 4.6 \\
\hline 339: Miscellaneous Manufacturing & 2.1 & 2.0 & 0.5 & 0.1 & 4.8 \\
\hline Total Energy Content (TBtu / yr) & 570 & 612 & 926 & 136 & 2,245 \\
\hline
\end{tabular}

The technical potential results in Table 7 do not account for WHP systems that are already installed. In the manufacturing sector, there is an estimated $671 \mathrm{MW}$ of installed WHP capacity, and Table 9 shows the remaining WHP technical potential after the installed capacity has been subtracted. ${ }^{24}$ This table shows that the remaining technical potential in the manufacturing sector is approximately $14.6 \mathrm{GW}(14,594 \mathrm{MW})$. Figure 13 shows a breakdown of the technical potential divided into four waste heat stream temperature ranges. As indicated, 37 percent of the technical potential is below $450{ }^{\circ} \mathrm{F}\left(12\right.$ percent $<300^{\circ} \mathrm{F}$ plus 25 percent in the $300-450^{\circ} \mathrm{F}$ range), 53 percent is in

24 The installed WHP capacity of 766 MW discussed in Section 5 includes manufacturing and nonmanufacturing sectors. The installed WHP capacity in only the manufacturing sector is estimated to be $671 \mathrm{MW}$. 
the $450-1,200^{\circ} \mathrm{F}$ range, and 10 percent of the remaining technical potential is above $1,200{ }^{\circ} \mathrm{F}$.

Table 9. Remaining WHP Technical Potential by NAICS Code (MW)

\begin{tabular}{|c|c|c|c|c|c|}
\hline \multirow[t]{2}{*}{ Industry } & \multicolumn{5}{|c|}{ Electric Power (MW) by Temperature Range ( $\left.{ }^{\circ} \mathrm{F}\right)$} \\
\hline & $<300$ & $300-450$ & $450-1200$ & $>1200$ & Total \\
\hline 311: Food Manufacturing & 13 & 182 & 157 & - & 352 \\
\hline $\begin{array}{l}\text { 312: Beverage and Tobacco Product } \\
\text { Manufacturing }\end{array}$ & 1 & 9 & 2 & - & 12 \\
\hline 313: Textile Mills & 32 & 11 & 4 & - & 47 \\
\hline 314: Textile Product Mills & - & - & - & - & 0 \\
\hline 315: Apparel Manufacturing & 2 & - & - & - & 2 \\
\hline $\begin{array}{l}\text { 316: Leather and Allied Product } \\
\text { Manufacturing }\end{array}$ & - & - & - & - & 0 \\
\hline 321: Wood Product Manufacturing & 160 & 242 & 27 & - & 429 \\
\hline 322: Paper Manufacturing & 129 & 567 & 42 & - & 737 \\
\hline $\begin{array}{l}\text { 323: Printing and Related Support } \\
\text { Activities }\end{array}$ & 40 & 19 & 29 & 13 & 100 \\
\hline $\begin{array}{l}\text { 324: Petroleum and Coal Products } \\
\text { Manufacturing }\end{array}$ & 320 & 687 & 5,628 & 64 & 6,698 \\
\hline 325: Chemical Manufacturing & 331 & 461 & 739 & 276 & 1,806 \\
\hline $\begin{array}{l}\text { 326: Plastics and Rubber Products } \\
\text { Manufacturing }\end{array}$ & 28 & 14 & 5 & 6 & 52 \\
\hline $\begin{array}{l}\text { 327: Nonmetallic Mineral Product } \\
\text { Manufacturing }\end{array}$ & 61 & 288 & 935 & 196 & 1,479 \\
\hline 331: Primary Metal Manufacturing & 499 & 337 & 62 & 899 & 1,796 \\
\hline $\begin{array}{l}\text { 332: Fabricated Metal Product } \\
\text { Manufacturing }\end{array}$ & 127 & 671 & 80 & - & 879 \\
\hline 333: Machinery Manufacturing & 17 & 34 & 11 & - & 62 \\
\hline $\begin{array}{l}\text { 334: Computer and Electronic Product } \\
\text { Manufacturing }\end{array}$ & 7 & 13 & - & - & 20 \\
\hline $\begin{array}{l}\text { 335: Electrical Equipment } \\
\text { Manufacturing }\end{array}$ & 6 & 8 & 2 & - & 16 \\
\hline $\begin{array}{l}\text { 336: Transportation Equipment } \\
\text { Manufacturing }\end{array}$ & 15 & 42 & 7 & - & 64 \\
\hline $\begin{array}{l}\text { 337: Furniture and Related Product } \\
\text { Manufacturing }\end{array}$ & 5 & 11 & 4 & 1 & 21 \\
\hline 339: Miscellaneous Manufacturing & 5 & 11 & 4 & 1 & 22 \\
\hline Share of Total & $\begin{array}{c}1,798 \\
12 \%\end{array}$ & $\begin{array}{c}3,607 \\
25 \%\end{array}$ & $\begin{array}{c}7,733 \\
53 \%\end{array}$ & $\begin{array}{c}1,455 \\
10 \%\end{array}$ & $\begin{array}{c}14,594 \\
100 \%\end{array}$ \\
\hline
\end{tabular}

Note: Small differences may occur due to rounding. 
Figure 13. Remaining Technical Potential (MW) for WHP in the Manufacturing Sector

(breakdown by waste heat stream temperature range)

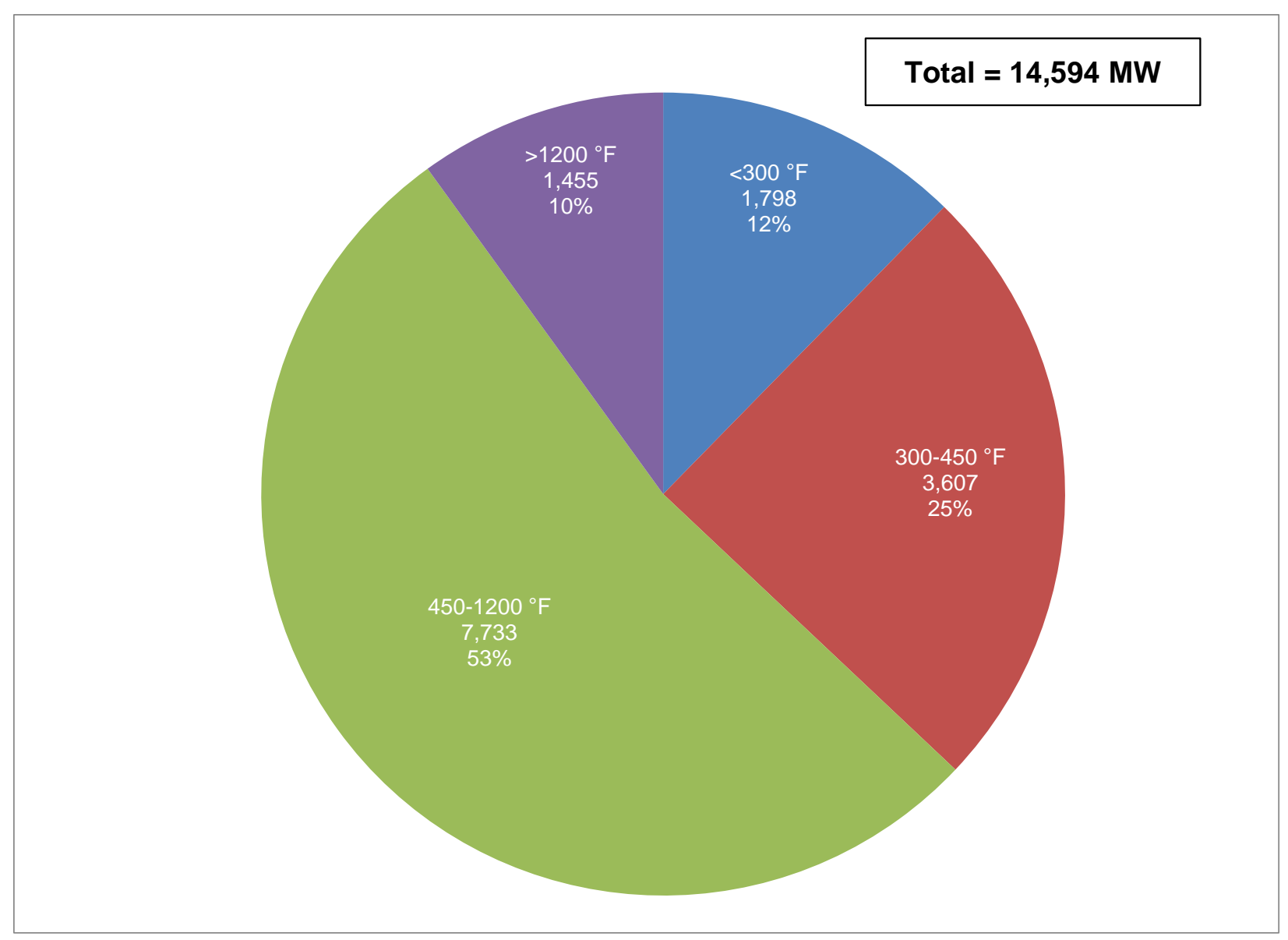




\section{Technical Potential $\left(\geq 450^{\circ} \mathrm{F}\right)$}

This chapter describes the methodology and presents the results of the technical potential of WHP using a "bottom-up" approach. In this approach, ICF identified candidate facilities in key market sectors and calculated the power generation capacity from waste heat streams for each facility. ICF relied on several databases to identify the facilities:

- EPA Greenhouse Gas Reporting Program (EPA GHGRP) database

- EIA Compressor Station database

- Oil and Gas Journal's Gas Processing Plants database

- Oil and Gas Journal's Refinery Survey

- Portland Cement Association's Cement Kilns database

- EPA Landfill database

- Association of Iron and Steel Engineer's Directory of Iron and Steel Plants

All of the databases, except for the EPA GHGRP database, cover a specific industry or application. Databases for a specific industry or application were used to identify facilities for that specific industry or application. For all other industries and applications, the EPA GHGRP database was used.

The technical potential analysis was constrained to waste heat sources with a temperature of $450^{\circ} \mathrm{F}$ or higher. Power generation from waste heat has been deemed to be generally economically feasible with medium- to high-temperature waste heat sources (i.e., $>450^{\circ} \mathrm{F}$ ). Thus, this section is based on an analysis that incorporates this temperature limit. ${ }^{25}$

Table 10 summarizes the estimates of the technical potential by market. The results show that there are currently at least 2,946 facilities within these markets that could potentially install WHP equipment. The top six markets (by 3-digit NAICS code) shown in Table 10 account for 96 percent of the total number of sites. Almost half of the sites (46 percent) are in compressor stations (NAICS 486). Landfills (NAICS 562), oil and gas plants (NAICS 211), non-metallic minerals (includes cement, lime, and glass plants, NAICS 327), petroleum and coal products (includes petroleum refining, NAICS 324), and primary metals (includes iron and steel plants and iron foundries, NAICS 331) round out the top six, all with more than 100 sites.

${ }^{25}$ Emerging technologies are expected to lower this temperature limit. 
Table 10. Waste Heat to Power Technical Potential, No. of Facilities by NAICS

\begin{tabular}{|c|c|c|c|}
\hline NAICS & NAICS Description & Count & Share \\
\hline 486 & Pipeline Transportation & 1,363 & $46.3 \%$ \\
\hline 562 & Waste Management & 478 & $16.2 \%$ \\
\hline 211 & Oil and Gas Extraction & 427 & $14.5 \%$ \\
\hline 327 & Total Non-Metallic Minerals & 255 & $8.7 \%$ \\
\hline 3272 & Non-Metallic Minerals - Glass & 93 & $3.2 \%$ \\
\hline 327310 & Non-Metallic Minerals - Cement & 111 & $3.8 \%$ \\
\hline 327410 & Non-Metallic Minerals - Lime & 32 & $1.1 \%$ \\
\hline Other 327 & Non-Metallic Minerals - Other & 19 & $0.6 \%$ \\
\hline 324 & Total Petroleum and Coal Products & 176 & $6.0 \%$ \\
\hline 324111 & Petroleum Refineries & 152 & $5.2 \%$ \\
\hline Other 324 & Petroleum and Coal - Other & 24 & $0.8 \%$ \\
\hline 331 & Total Primary Metals & 116 & $3.9 \%$ \\
\hline 331111 & Primary Metals - Iron and Steel & 92 & $3.1 \%$ \\
\hline 331511 & Primary Metals - Iron Foundries & 14 & $0.5 \%$ \\
\hline Other 331 & Primary Metals - Other & 9 & $0.3 \%$ \\
\hline 325 & Chemical & 64 & $2.2 \%$ \\
\hline 311 & Food & 19 & $0.6 \%$ \\
\hline 322 & Paper & 17 & $0.6 \%$ \\
\hline 212 & Mining, Except Oil and Gas & 14 & $0.5 \%$ \\
\hline 334 & Computer and Electronic Products & 4 & $0.1 \%$ \\
\hline 312 & Beverage and Tobacco & 2 & $0.1 \%$ \\
\hline 321 & Wood & 2 & $0.1 \%$ \\
\hline 326 & Rubber & 2 & $0.1 \%$ \\
\hline 333 & Machinery & 2 & $0.1 \%$ \\
\hline 611 & Colleges & 2 & $0.1 \%$ \\
\hline 323 & Printing & 1 & $<0.1 \%$ \\
\hline 336 & Transportation Equipment & 1 & $<0.1 \%$ \\
\hline 493 & Warehousing and Storage & 1 & $<0.1 \%$ \\
\hline- & Total & 2,946 & $100 \%$ \\
\hline
\end{tabular}

In terms of capacity, the total technical potential for WHP in these market sectors is 8,840 MW. Table 11 shows that the same top six markets identified in Table 10 as having the most sites also have the largest potential in terms of capacity. The top six markets account for over 98 percent of total potential capacity. The largest potential is in petroleum and coal products (NAICS 324) at 3,593 MW, or 41 percent of the total potential, followed by primary metals (NAICS 331), non-metallic minerals industries (NAICS 327), compressor stations (NAICS 486), oil and gas plants (NAICS 211), and landfills. The primary metals sites include mostly iron and steel plants, while the nonmetallic minerals industries include cement, lime, and glass plants. 
Table 11. Waste Heat to Power Technical Potential, Capacity by NAICS

\begin{tabular}{|c|l|c|c|}
\hline NAICS & \multicolumn{1}{|c|}{ NAICS Description } & $\begin{array}{c}\text { Capacity } \\
\text { (MW) }\end{array}$ & $\begin{array}{c}\text { Share of } \\
\text { Total }\end{array}$ \\
\hline 324 & Total Petroleum and Coal Products & 3,593 & $40.6 \%$ \\
\hline 324111 & Petroleum Refining & 3,502 & $39.6 \%$ \\
\hline Other 324 & Other Petroleum and Coal & 91 & $1.0 \%$ \\
\hline 331 & Total Primary Metals & $2,186{ }^{26}$ & $24.7 \%$ \\
\hline 331111 & Primary Metals - Iron and Steel & 2,129 & $24.1 \%$ \\
\hline 331511 & Primary Metals - Iron Foundries & 44 & $0.5 \%$ \\
\hline Other 331 & Primary Metals - Other & 13 & $0.1 \%$ \\
\hline 327 & Total Non-Metallic Minerals & 1,173 & $13.3 \%$ \\
\hline 3272 & Non-Metallic Minerals - Glass & 340 & $3.8 \%$ \\
\hline 327310 & Non-Metallic Minerals - Cement & 665 & $7.5 \%$ \\
\hline 327410 & Non-Metallic Minerals - Lime & 148 & $1.7 \%$ \\
\hline Other 327 & Non-Metallic Minerals - Other & 20 & $0.2 \%$ \\
\hline 486 & Pipeline Transportation & 1,102 & $12.5 \%$ \\
\hline 211 & Oil and Gas Extraction & 538 & $6.1 \%$ \\
\hline 562 & Waste Management & 113 & $1.3 \%$ \\
\hline 325 & Chemical & 92 & $1.0 \%$ \\
\hline 212 & Mining, except Oil and Gas & 23 & $0.3 \%$ \\
\hline 311 & Food & 8 & $0.1 \%$ \\
\hline 322 & Paper & 5 & $0.1 \%$ \\
\hline 333 & Machinery & 4 & $<0.1 \%$ \\
\hline 336 & Transportation Equipment & 2 & $<0.1 \%$ \\
\hline 321 & Wood & 0.5 & $<0.1 \%$ \\
\hline 312 & Beverage and Tobacco & 0.3 & $<0.1 \%$ \\
\hline 323 & Printing & 0.1 & $<0.1 \%$ \\
\hline 334 & Computer and Electronic Products & 0.1 & $<0.1 \%$ \\
\hline 611 & Colleges & 0.1 & $<0.1 \%$ \\
\hline 326 & Rubber & $<0.1$ & $<0.1 \%$ \\
\hline 493 & Warehousing and Storage & $<0.1$ & $<0.1 \%$ \\
\hline & Total & 8,840 & $100 \%$ \\
\hline & & & \\
\hline
\end{tabular}

Table 11 includes data for the manufacturing sector (NAICS $31-33$ ) as well as six NAICS codes outside the manufacturing sector $(211,212,486,493,562$, and 611). Approximately 80 percent $(7,064 \mathrm{MW})$ of the capacity listed in Table 11 falls within the manufacturing sector (see Table 12).

\footnotetext{
${ }^{26}$ It is noted that the total technical potential using the bottom-up approach for NAICS $331(2,186 \mathrm{MW})$ is more than the technical potential estimated using the top-down approach (974 MW for waste heat temperature range of $400-500^{\circ} \mathrm{F}$ and above). This anomaly reflects the inherent data quality issues of the sources used in the top-down approach. The bottom-up approach used a more detailed level of information on equipment and process, assuring a more rigorous methodology.
} 
Table 12. Waste Heat to Power Technical Potential, Capacity by Sector

\begin{tabular}{|c|c|c|c|}
\hline NAICS & Sector & Capacity (MW) & Share of Total \\
\hline $31-33$ & Manufacturing & 7,064 & $79.9 \%$ \\
\hline $\begin{array}{c}211,212,486,493, \\
562,611\end{array}$ & Other Than Manufacturing & 1,776 & $20.1 \%$ \\
\hline- & & 8,840 & $100 \%$ \\
\hline
\end{tabular}

Figure 14 shows the distribution of potential WHP sites by state. Texas has 417 potential sites, which is the largest number of sites for a single state, representing over 14 percent of total sites. Louisiana and Pennsylvania are a distant second and third in number of sites, at 202 and 192, respectively. These three states have large numbers of compressor stations that contribute to the technical potential for WHP. Texas also has many cement plants with WHP potential (additional details in Appendix B).

\section{Figure 14. WHP Technical Potential by State (number of sites)}

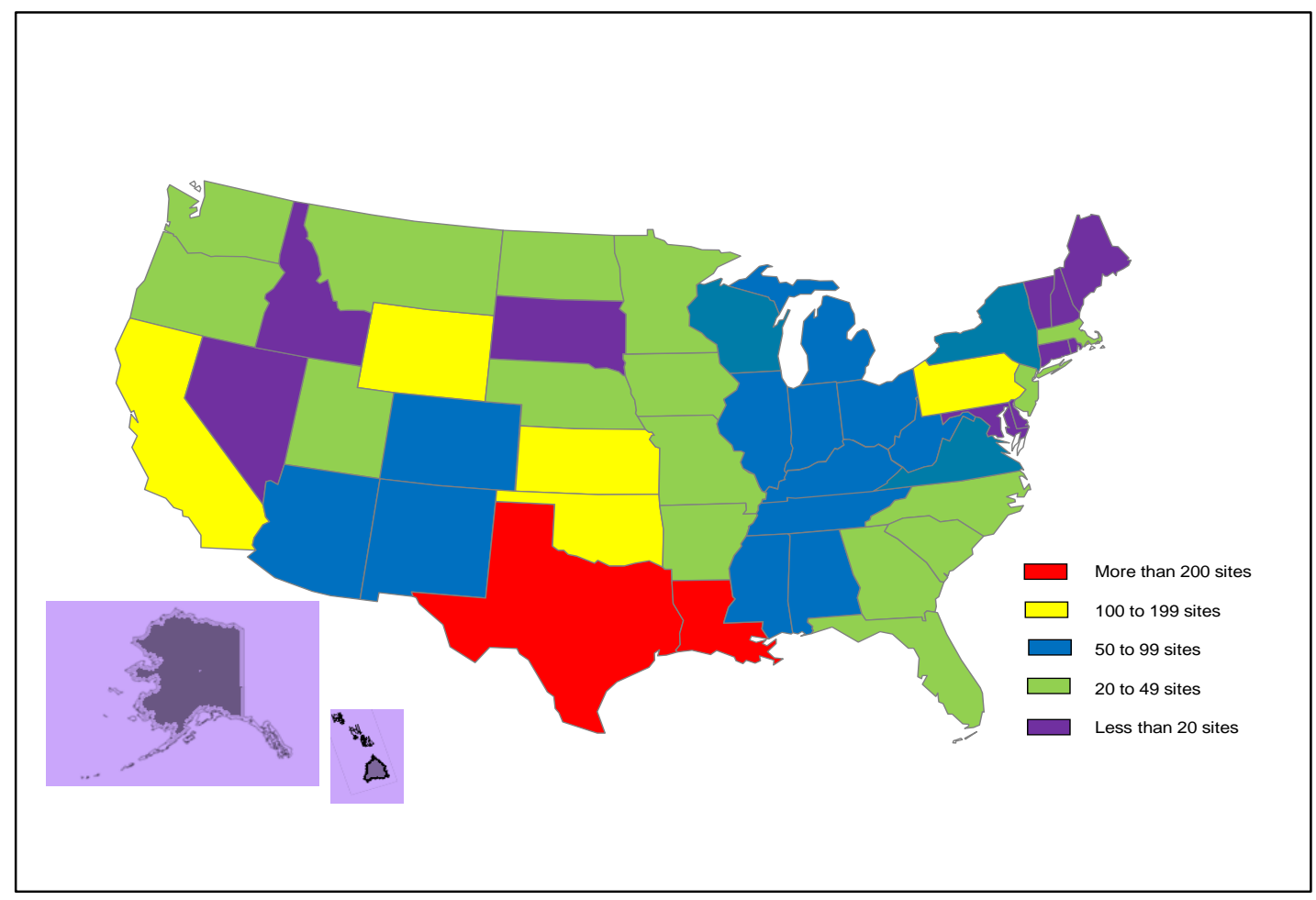

Table 13 shows that Texas has the largest WHP technical potential capacity with 1,515 MW, or 17 percent of total capacity. Louisiana and California have the second and third largest potential capacity at $884 \mathrm{MW}$ and $763 \mathrm{MW}$, respectively. The technical potential in these three states is driven by petroleum refineries, oil and gas operations, cement plants, and pipeline compressor stations. A distribution of technical potential capacity by state is shown in Figure 15. 
Table 13. Waste Heat to Power Technical Potential, Capacity by State

\begin{tabular}{|c|c|c|}
\hline State & $\begin{array}{c}\text { Capacity } \\
\text { (MW) }\end{array}$ & Share of Total \\
\hline TX & $1,515.19$ & $17.1 \%$ \\
\hline LA & 883.8 & $10.0 \%$ \\
\hline CA & 763.4 & $8.6 \%$ \\
\hline IN & 501.4 & $5.7 \%$ \\
\hline PA & 482.6 & $5.5 \%$ \\
\hline IL & 385.6 & $4.4 \%$ \\
\hline OH & 336.9 & $3.8 \%$ \\
\hline AL & 293.5 & $3.3 \%$ \\
\hline KY & 247.6 & $2.8 \%$ \\
\hline MS & 242.3 & $2.7 \%$ \\
\hline MI & 196.1 & $2.2 \%$ \\
\hline OK & 182.5 & $2.1 \%$ \\
\hline AR & 180.3 & $2.0 \%$ \\
\hline KS & 176.7 & $2.0 \%$ \\
\hline WA & 170.3 & $1.9 \%$ \\
\hline WV & 168.8 & $1.9 \%$ \\
\hline SC & 160.9 & $1.8 \%$ \\
\hline MN & 151.7 & $1.7 \%$ \\
\hline WY & 127.0 & $1.4 \%$ \\
\hline TN & 121.4 & $1.4 \%$ \\
\hline NJ & 116.7 & $1.3 \%$ \\
\hline CO & 108.5 & $1.2 \%$ \\
\hline IA & 105.1 & $1.2 \%$ \\
\hline MO & 98.2 & $1.1 \%$ \\
\hline NC & 90.5 & $1.0 \%$ \\
\hline & & \\
\hline & & \\
\hline
\end{tabular}

\begin{tabular}{|c|c|c|}
\hline State & $\begin{array}{c}\text { Capacity } \\
\text { (MW) }\end{array}$ & $\begin{array}{c}\text { Share of } \\
\text { Total }\end{array}$ \\
\hline FL & 85.7 & $1.0 \%$ \\
\hline VA & 84.9 & $1.0 \%$ \\
\hline NY & 82.6 & $0.9 \%$ \\
\hline AZ & 78.9 & $0.9 \%$ \\
\hline UT & 78.8 & $0.9 \%$ \\
\hline NM & 75.3 & $0.9 \%$ \\
\hline AK & 72.9 & $0.8 \%$ \\
\hline WI & 70.1 & $0.8 \%$ \\
\hline MT & 68.0 & $0.8 \%$ \\
\hline DE & 60.7 & $0.7 \%$ \\
\hline NE & 50.8 & $0.6 \%$ \\
\hline OR & 47.8 & $0.5 \%$ \\
\hline MD & 44.6 & $0.5 \%$ \\
\hline GA & 27.6 & $0.3 \%$ \\
\hline ND & 22.1 & $0.3 \%$ \\
\hline ID & 19.9 & $0.2 \%$ \\
\hline SD & 15.1 & $0.2 \%$ \\
\hline NV & 13.3 & $0.2 \%$ \\
\hline MA & 10.6 & $0.1 \%$ \\
\hline ME & 7.6 & $0.1 \%$ \\
\hline HI & 7.4 & $0.1 \%$ \\
\hline RI & 3.4 & $0.0 \%$ \\
\hline CT & 3.1 & $0.0 \%$ \\
\hline VT & 1.0 & $0.0 \%$ \\
\hline NH & 0.7 & $0.0 \%$ \\
\hline Total & 8,840 & $100 \%$ \\
\hline & & \\
\hline & & \\
\hline
\end{tabular}


Figure 15. WHP Technical Potential by State (capacity)

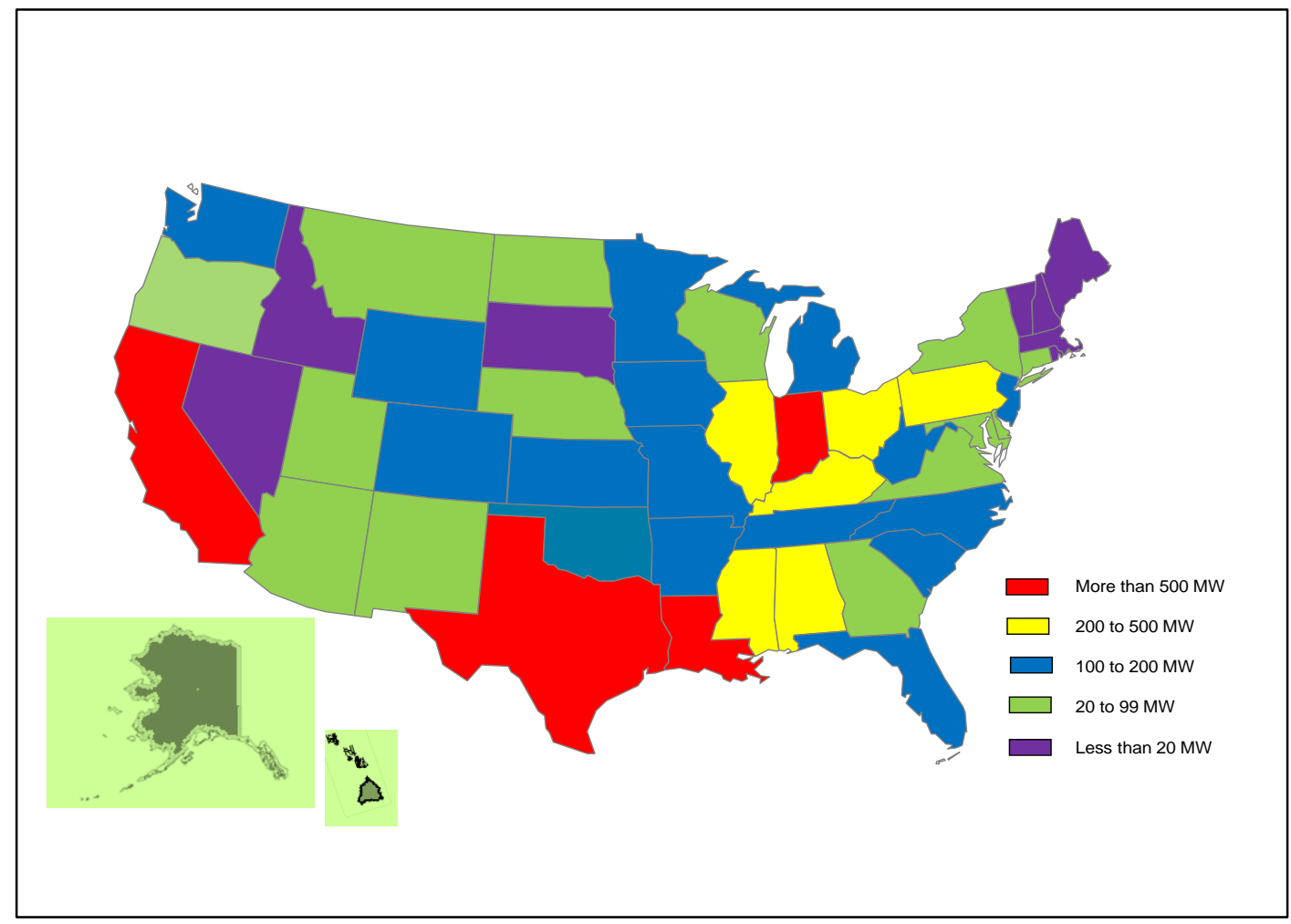




\section{Economic Potential $\left(\geq 450^{\circ} \mathrm{F}\right)$}

The previous sections provided an estimate of the technical potential for WHP systems. In this section, the economic potential and expected market penetration are estimated based on economic factors including capital costs, operating and maintenance (O\&M) costs, and the cost of grid electricity. The economic potential estimates are based on cost characteristics of WHP systems and do not include the impact of any incentives that may be available. This analysis is limited to waste heat sources $\geq 450 \mathrm{~F}$, which represent the sources that can be recovered with commercially available WHP technologies. A site-by-site analysis was found to be more appropriate in evaluating the market acceptance of WHP, and site data were only developed for sources with waste heat temperature $\geq 450^{\circ} \mathrm{F}$.

For each site included in the technical potential, an economic payback is calculated, and this payback value is used as an indicator of the likelihood that a particular site will install a WHP system. The likelihood is termed the market acceptance factor. For this study, the market acceptance factor is based on a national survey of potential combined heat and power (CHP) customers that assessed the percentage of customers that would move forward with a project at a given payback. It is assumed that the acceptance factor for WHP is similar to the acceptance factor for CHP. The sum of the economic potentials multiplied by the market acceptance factors represents the expected market penetration - or the estimated quantity of WHP that will likely enter the market.

\subsection{Cost and Performance Information}

The cost and performance data discussed in Section 3 for WHP equipment were used to calculate the payback for each site. The following assumptions were also made for this economic analysis:

- All sites are assumed to install either Steam Rankine Cycle (SRC) or Organic Rankine Cycle (ORC) technologies. These two technologies are commercially available, and nearly all WHP installations currently use one of these two technologies. Over time, new technologies may enter the market (e.g., Kalina and super critical $\mathrm{CO}_{2}$ ), but at the present time $\mathrm{SRC}$ and $\mathrm{ORC}$ are the commercially available technologies in the United States.

- The temperature of a waste heat stream has a significant influence on the type of technology that will be installed. Based on waste heat stream characteristics, it was assumed that ORC technology will be installed in compressor stations, gas processing plants, and other mining facilities. All other sites are assumed to install SRC. In practice, SRC and ORC technologies will overlap, and both 
systems will be installed in some industrial sectors. For the economic analysis in this report, however, the SRC and ORC technologies are assumed to be divided along NAICS codes as show in Table 14.

- ICF differentiated costs by size to infer economies of scale. Thus, higher capital and O\&M costs were assigned to smaller capacity equipment, and lower costs were assigned to larger capacity equipment. Table 15 shows the costs used in the payback calculations (development of costs are discussed in Section 3.3).

Table 14. Technology Assignment by NAICS Code

\begin{tabular}{|c|c|c|}
\hline NAICS & NAICS Description & $\begin{array}{c}\text { WHP } \\
\text { Technology }\end{array}$ \\
\hline 211 & Oil and Gas Extraction & ORC \\
\hline 212 & Mining except Oil and Gas & ORC \\
\hline 311 & Food & SRC \\
\hline 312 & Beverage and Tobacco & SRC \\
\hline 321 & Wood & SRC \\
\hline 322 & Paper & SRC \\
\hline 323 & Printing & SRC \\
\hline 324 & Petroleum Refining & SRC \\
\hline 325 & Chemical & SRC \\
\hline 327 & Non-Metallic Minerals & SRC \\
\hline 331 & Primary Metals & SRC \\
\hline 333 & Machinery & SRC \\
\hline 336 & Transportation Equipment & SRC \\
\hline 486 & Pipeline Transportation & ORC \\
\hline 562 & Waste Management & ORC \\
\hline 611 & Colleges & SRC \\
\hline
\end{tabular}

Table 15. Waste Heat to Power Cost Assumptions

\begin{tabular}{|c|c|c|c|c|c|c|}
\hline \multirow{2}{*}{ Technology } & \multirow{2}{*}{$\begin{array}{c}\text { Cost } \\
\text { Characteristic }\end{array}$} & \multicolumn{5}{|c|}{ Capacity for WHP Technology } \\
\hline & & $50-500 \mathrm{~kW}$ & $500-1,000 \mathrm{~kW}$ & $1-5 \mathrm{MW}$ & $5-20 \mathrm{MW}$ & $>20 \mathrm{MW}$ \\
\hline \multirow{2}{*}{$\begin{array}{c}\text { Steam } \\
\text { Rankine } \\
\text { Cycle }\end{array}$} & $\begin{array}{c}\text { Installed Capital } \\
\text { Cost }(\$ / \mathrm{kW})\end{array}$ & $\$ 3,000$ & $\$ 2,500$ & $\$ 1,800$ & $\$ 1,500$ & $\$ 1,200$ \\
\hline & $\begin{array}{l}\text { O\&M Costs } \\
(\$ / k W h)\end{array}$ & $\$ 0.013$ & $\$ 0.009$ & $\$ 0.008$ & $\$ 0.006$ & $\$ 0.005$ \\
\hline \multirow{2}{*}{$\begin{array}{c}\text { Organic } \\
\text { Rankine } \\
\text { Cycle }\end{array}$} & $\begin{array}{l}\text { Installed Capital } \\
\text { Cost }(\$ / \mathrm{kW})\end{array}$ & $\$ 4,500$ & $\$ 4,000$ & $\$ 3,000$ & $\$ 2,500$ & $\$ 2,100$ \\
\hline & $\begin{array}{c}\text { O\&M Costs } \\
(\$ / k W h)\end{array}$ & $\$ 0.020$ & $\$ 0.015$ & $\$ 0.013$ & $\$ 0.012$ & $\$ 0.010$ \\
\hline
\end{tabular}




\subsection{State Analysis}

The economic benefits of a WHP system are based on electricity cost savings. For this study, grid electricity prices in the industrial sector were analyzed at the state level (see Table 16). The states with the highest electricity rates are Hawaii, Alaska, Massachusetts, Connecticut, New Hampshire, New York and New Jersey. The states with the lowest electricity rates are Washington, Utah, Idaho, lowa, and Montana.

It is important to note that using a state average electricity price for the industrial sector also causes limitations. Specific utility rates within each state may differ based on the exact location of the potential WHP system.

Table 16. Electricity Prices by State

\begin{tabular}{|c|c|}
\hline State & $\begin{array}{c}\text { Electric Price } \\
(\$ \mathrm{kWh})\end{array}$ \\
\hline Alabama & $\$ 0.06$ \\
\hline Alaska & $\$ 0.16$ \\
\hline Arizona & $\$ 0.07$ \\
\hline Arkansas & $\$ 0.06$ \\
\hline California & $\$ 0.10$ \\
\hline Colorado & $\$ 0.07$ \\
\hline Connecticut & $\$ 0.13$ \\
\hline Delaware & $\$ 0.09$ \\
\hline Florida & $\$ 0.09$ \\
\hline Georgia & $\$ 0.07$ \\
\hline Hawaii & $\$ 0.28$ \\
\hline Idaho & $\$ 0.05$ \\
\hline Illinois & $\$ 0.06$ \\
\hline Indiana & $\$ 0.06$ \\
\hline lowa & $\$ 0.05$ \\
\hline Kansas & $\$ 0.07$ \\
\hline Kentucky & $\$ 0.05$ \\
\hline Louisiana & $\$ 0.06$ \\
\hline Maine & $\$ 0.09$ \\
\hline Maryland & $\$ 0.09$ \\
\hline Massachusetts & $\$ 0.13$ \\
\hline Michigan & $\$ 0.07$ \\
\hline Minnesota & $\$ 0.07$ \\
\hline Mississippi & $\$ 0.07$ \\
\hline Missouri & $\$ 0.06$ \\
\hline
\end{tabular}

\begin{tabular}{|c|c|}
\hline State & $\begin{array}{c}\text { Electric Price } \\
(\$ / \mathrm{kWh})\end{array}$ \\
\hline Montana & $\$ 0.05$ \\
\hline Nebraska & $\$ 0.06$ \\
\hline Nevada & $\$ 0.07$ \\
\hline New Hampshire & $\$ 0.12$ \\
\hline New Jersey & $\$ 0.11$ \\
\hline New Mexico & $\$ 0.06$ \\
\hline New York & $\$ 0.12$ \\
\hline North Carolina & $\$ 0.06$ \\
\hline North Dakota & $\$ 0.06$ \\
\hline Ohio & $\$ 0.06$ \\
\hline Oklahoma & $\$ 0.06$ \\
\hline Oregon & $\$ 0.06$ \\
\hline Pennsylvania & $\$ 0.08$ \\
\hline Rhode Island & $\$ 0.11$ \\
\hline South Carolina & $\$ 0.06$ \\
\hline South Dakota & $\$ 0.06$ \\
\hline Tennessee & $\$ 0.07$ \\
\hline Texas & $\$ 0.06$ \\
\hline Utah & $\$ 0.05$ \\
\hline Vermont & $\$ 0.10$ \\
\hline Virginia & $\$ 0.07$ \\
\hline Washington & $\$ 0.04$ \\
\hline West Virginia & $\$ 0.06$ \\
\hline Wisconsin & $\$ 0.07$ \\
\hline Wyoming & $\$ 0.05$ \\
\hline & \\
\hline
\end{tabular}

Source: EIA, 2012 


\subsection{Payback}

Given the costs and performance data and the state electricity prices, the simple payback (in years) was calculated for a WHP system at each site identified in the technical potential inventory. Table 17 shows the average payback by market. The results show that payback values range from 3.0 to 22.3 years, with an average of 4.5 years. The industries with the shortest paybacks are petroleum refining, primary metals, and non-metallic minerals. It is important to note that these industries also have some of the largest technical potential in terms of WHP capacity. Nevertheless, the pipeline transportation sector, which also has a significant technical potential, has a relatively long payback (9.8 years). This relatively high payback period is driven by the higher capital cost of applicable WHP technology (ORC). The longest payback is in the beverage industry (NAICS 312). ${ }^{27}$

Table 17. Average Payback by NAICS

\begin{tabular}{|c|c|c|}
\hline NAICS & NAICS Description & Average Payback (years) \\
\hline 211 & Oil and Gas Extraction & 8.3 \\
\hline 212 & Mining except Oil and Gas & 11.1 \\
\hline 311 & Food & 8.6 \\
\hline 312 & Beverage and Tobacco & 22.3 \\
\hline 321 & Wood & 11.8 \\
\hline 322 & Paper & 14.8 \\
\hline 323 & Printing & 12.0 \\
\hline 324 & Petroleum Refining & 3.0 \\
\hline 325 & Chemical & 6.5 \\
\hline 326 & Rubber & 6.8 \\
\hline 327 & Non-Metallic Minerals & 3.9 \\
\hline 331 & Primary Metals & 3.1 \\
\hline 333 & Machinery & 4.9 \\
\hline 334 & Computer and Electronics & 6.3 \\
\hline 336 & Transportation Equipment & 10.7 \\
\hline 486 & Pipeline Transportation & 9.8 \\
\hline 493 & Warehousing and Storage & 16.7 \\
\hline 562 & Waste Management & 10.4 \\
\hline 611 & Colleges & 11.8 \\
\hline--- & Average for All Industries & 4.5 \\
\hline
\end{tabular}

Another interesting way to look at the payback results is to examine them by payback ranges (see Table 18). As indicated, $892 \mathrm{MW}$, or 10 percent, of WHP technical potential

${ }^{27}$ There is only one site under this NAICS code. Its WHP capacity is less than $300 \mathrm{~kW}$ with a low load factor. 
capacity has a payback of less than 2 years. A large portion of this capacity is in petroleum refining. Significant capacity also exists in oil and gas mining, primary metals, and non-metallic minerals. The payback range with the largest total capacity is between 2 and 5 years. Over 66 percent $(5,868 \mathrm{MW})$ of WHP technical potential capacity has a payback within this range. A majority of petroleum refining, primary metals, and nonmetallic minerals has payback less than 5 years. Finally, 24 percent of total WHP capacity $(2,080 \mathrm{MW})$ has a payback of more than 5 years.

Table 18. WHP Technical Potential Capacity by Payback Range, NAICS

\begin{tabular}{|c|l|c|c|c|c|}
\hline \multirow{2}{*}{ NAICS } & \multirow{2}{*}{ NAICS Description } & \multicolumn{3}{|c|}{ Capacity (MW) by Payback Range } \\
\cline { 3 - 6 } & & $<2$ yrs & 2 to 5 yrs & $>5$ yrs & Total \\
\hline 211 & Oil and Gas Extraction & 60.2 & 8.3 & 469.5 & 538.0 \\
\hline 212 & Mining except Oil and Gas & 0.0 & 2.8 & 19.8 & 22.6 \\
\hline 311 & Food & 0.0 & 3.7 & 4.5 & 8.2 \\
\hline 312 & Beverage and Tobacco & 0.0 & 0.0 & 0.3 & 0.3 \\
\hline 321 & Wood & 0.0 & 0.0 & 0.5 & 0.5 \\
\hline 322 & Paper & 0.0 & 0.7 & 3.9 & 4.6 \\
\hline 323 & Printing & 0.0 & 0.0 & 0.1 & 0.1 \\
\hline 324 & Petroleum and Coal Products & 700.7 & $2,753.4$ & 139.0 & $3,593.1$ \\
\hline 32411 & Petroleum Refining & 700.7 & $2,737.8$ & 63.7 & $3,502.2$ \\
\hline Other 324 & Other Petroleum and Coal & 0.0 & 15.6 & 75.3 & 90.9 \\
\hline 325 & Chemical & 0.0 & 45.1 & 47.2 & 92.4 \\
\hline 326 & Rubber & 0.0 & 0.01 & 0.02 & 0.03 \\
\hline 327 & Non-Metallic Minerals & 53.6 & 938.4 & 180.9 & $1,172.9$ \\
\hline 3272 & Glass & 8.4 & 247.8 & 83.7 & 340.0 \\
\hline 327310 & Cement & 45.1 & 580.5 & 39.2 & 664.8 \\
\hline 327410 & Lime & 0.0 & 101.3 & 47.0 & 148.3 \\
\hline Other 327 & Other Non-Metallic Minerals & 0.1 & 8.8 & 11.0 & 19.9 \\
\hline 331 & Primary Metals & 77.1 & $2,066.4$ & 42.3 & $2,185.9$ \\
\hline 331111 & Iron and Steel & 77.1 & $2,051.2$ & 0.3 & $2,128.7$ \\
\hline 331511 & Iron Foundries & 0.0 & 15.2 & 28.9 & 44.1 \\
\hline Other 331 & Other Primary Metals & 0.0 & 0.0 & 13.1 & 13.1 \\
\hline 333 & Machinery & 0.0 & 3.6 & 0.2 & 3.9 \\
\hline 334 & Computer and Electronics & 0.0 & 0.1 & 0.0 & 0.1 \\
\hline 336 & Transportation Equipment & 0.0 & 0.0 & 1.8 & 1.8 \\
\hline 486 & Pipeline Transportation & 0.0 & 40.3 & $1,061.8$ & $1,102.1$ \\
\hline 493 & Warehousing and Storage & 0.0 & 0.0 & 0.0 & 0.0 \\
\hline 562 & Waste Management & 0.0 & 4.8 & 108.3 & 113.1 \\
\hline 611 & Colleges & 0.0 & 0.0 & 0.1 & 0.1 \\
\hline Total & --- & 892 & 5,868 & 2,080 & 8,840 \\
\hline
\end{tabular}

Table 19 shows the payback results by state. The table shows that Hawaii, California, Alaska, Delaware, New Jersey, and Maryland offer the shortest paybacks (less than 3 
years). These states have some of the highest electricity prices. Further, among these six states, only California has a large WHP technical potential capacity. Texas, which has the largest WHP technical potential capacity, has an average payback of 4.2 years. Louisiana, the state with the third largest WHP technical potential capacity has an average payback of 5.3 years, which is longer than the overall average of 4.5 years.

Table 19. Average Payback (Years) by State

\begin{tabular}{|c|c|}
\hline State & Payback \\
\hline $\mathrm{HI}$ & 0.9 \\
\hline $\mathrm{CA}$ & 2.0 \\
\hline $\mathrm{AK}$ & 2.0 \\
\hline $\mathrm{DE}$ & 2.1 \\
\hline $\mathrm{NJ}$ & 2.1 \\
\hline $\mathrm{MD}$ & 2.7 \\
\hline $\mathrm{NY}$ & 3.2 \\
\hline $\mathrm{IN}$ & 3.5 \\
\hline $\mathrm{PA}$ & 3.6 \\
\hline $\mathrm{SC}$ & 3.6 \\
\hline $\mathrm{FL}$ & 3.7 \\
\hline $\mathrm{IL}$ & 4.0 \\
\hline $\mathrm{OH}$ & 4.1 \\
\hline $\mathrm{MN}$ & 4.2 \\
\hline $\mathrm{TX}$ & 4.2 \\
\hline $\mathrm{MA}$ & 4.2 \\
\hline $\mathrm{WV}$ & 4.3 \\
\hline $\mathrm{Ml}$ & 4.4 \\
\hline $\mathrm{MS}$ & 4.5 \\
\hline $\mathrm{AR}$ & 4.5 \\
\hline $\mathrm{TN}$ & 4.6 \\
\hline $\mathrm{AL}$ & 4.6 \\
\hline $\mathrm{ME}$ & 4.6 \\
\hline $\mathrm{NC}$ & 4.7 \\
\hline $\mathrm{CT}$ & 4.8 \\
\hline $\mathrm{MO}$ & 5.1 \\
\hline
\end{tabular}

\begin{tabular}{|c|c|}
\hline State & Payback \\
\hline KY & 5.1 \\
\hline LA & 5.3 \\
\hline RI & 5.3 \\
\hline NE & 5.3 \\
\hline WI & 5.4 \\
\hline MT & 5.5 \\
\hline CO & 5.6 \\
\hline KS & 5.7 \\
\hline VA & 5.7 \\
\hline VT & 5.7 \\
\hline NH & 5.9 \\
\hline IA & 6.1 \\
\hline NV & 6.3 \\
\hline SD & 6.4 \\
\hline AZ & 6.7 \\
\hline UT & 6.9 \\
\hline OK & 6.9 \\
\hline GA & 7.2 \\
\hline WA & 7.3 \\
\hline ND & 7.8 \\
\hline OR & 8.0 \\
\hline NM & 8.7 \\
\hline WY & 10.0 \\
\hline ID & 12.0 \\
\hline Total & 4.5 \\
\hline
\end{tabular}

Finally, Table 20 shows the payback results by the two WHP technologies evaluated. There is a large difference in the average paybacks of the two technologies. While most of the SRC capacity is within the 2-3 and 3-5 year payback ranges, almost all of the ORC capacity have paybacks over 5 years. The ORC has a higher capital cost, and the industries that are assumed to install it (oil and gas extraction, mining, and compressor stations) are generally in lower grid electricity cost states. It is noted that the economic potential calculations used average state electricity prices for the industrial sector. 
Table 20. WHP Technical Potential for ORC and SRC Technologies

\begin{tabular}{|c|c|c|c|c|c|}
\hline \multirow{2}{*}{ Technology } & \multicolumn{4}{|c|}{ Payback (yrs) } & Technical \\
\cline { 2 - 5 } & $<2$ & $2-3$ & $3-5$ & $>5$ & Potential (MW) \\
\hline Steam Rankine Cycle (SRC) & 832 & 3,146 & 2,665 & 421 & 7,064 \\
\hline Organic Rankine Cycle (ORC) & 60 & 6 & 51 & 1,659 & 1,776 \\
\hline Total & 892 & 3,152 & 2,716 & 2,080 & 8,840 \\
\hline
\end{tabular}

\subsection{Expected Market Penetration}

Market acceptance represents the likelihood that a site will install a WHP technology. For this WHP study, market acceptance is based on a national survey of potential combined heat and power (CHP) customers. It is assumed that acceptance behavior for WHP will be similar to CHP. The market acceptance curve shows the likelihood that an end user will install WHP based on payback. Even at low payback values, not all users will move forward with a WHP project due to perceived risk, competing needs for capital funds, or other site specific issues. The sum of the technical potential in each payback range multiplied by the market acceptance factors represents the expected market penetration - or the estimated quantity of WHP that will enter the market. Additional market acceptance details are provided in Appendix A.

This analysis shows that 33 percent $(2,904 \mathrm{MW})$ of the total technical potential $(8,840$ MW) is anticipated to be accepted in the market (see Table 21). As expected, market penetration is highest for the lowest payback category (less than 2 years), with 56 percent of the total technical potential being accepted in the market. The lowest market penetration occurs among facilities with the longest payback (more than 5 years), with only 8 percent of total technical potential capacity resulting in viable projects.

Collectively, facilities with paybacks under 5 years account 2,736 MW $(<2$ yrs $=500$ $\mathrm{MW}, 2-3 \mathrm{yrs}=1,324 \mathrm{MW}, 3-5 \mathrm{yrs}=912 \mathrm{MW}$ ) of market penetration, representing $94 \%$ of total market penetration (2,904 MW).

Table 21. Expected Market Penetration $\left(\geq 450^{\circ} \mathrm{F}\right)$

\begin{tabular}{|c|c|c|c|c|}
\hline \multirow{2}{*}{$\begin{array}{c}\text { Payback } \\
\text { (yrs) }\end{array}$} & \multirow{2}{*}{$\begin{array}{c}\text { Technical } \\
\text { Potential } \\
(\mathrm{MW})\end{array}$} & \multirow{2}{*}{$\begin{array}{c}\text { Market } \\
\text { Penetration } \\
(\mathrm{MW})\end{array}$} & \multicolumn{2}{|c|}{ Market Penetration (\%) } \\
\hline & & & $\begin{array}{c}\text { Share of Technical Potential } \\
\text { Within Payback Range }\end{array}$ & $\begin{array}{c}\text { Share of Total Market } \\
\text { Penetration }\end{array}$ \\
\hline$<2$ & 892 & 500 & $56 \%$ & $17.2 \%$ \\
\hline $2-3$ & 3,152 & 1,324 & $42 \%$ & $45.6 \%$ \\
\hline $3-5$ & 2,716 & 912 & $34 \%$ & $31.4 \%$ \\
\hline$>5$ & 2,080 & 168 & $8 \%$ & $5.8 \%$ \\
\hline All & 8,840 & 2,904 & $33 \%$ & $100 \%$ \\
\hline
\end{tabular}


Table 22 shows the market penetration by market sector (NAICS). The results show that 2,904 MW or 33 percent of the total technical potential capacity is likely to ultimately enter the market. Petroleum and coal products has the largest market penetration, with $1,488 \mathrm{MW}$, followed by primary metals ( $850 \mathrm{MW}$ ), non-metallic minerals ( $385 \mathrm{MW}$ ), pipeline transportation (77 MW), and oil and gas extraction (73 MW). These same industries also have the highest WHP technical potential capacity and the shortest payback results.

Table 22. Expected Market Penetration by Market Sector

\begin{tabular}{|c|c|c|c|c|}
\hline \multirow[t]{2}{*}{ NAICS } & \multirow[t]{2}{*}{ NAICS Description } & \multirow{2}{*}{$\begin{array}{c}\text { Technical } \\
\text { Potential (MW) }\end{array}$} & \multicolumn{2}{|c|}{ Market Penetration } \\
\hline & & & $(\mathrm{MW})$ & $(\%)$ \\
\hline 324 & Total Petroleum and Coal Products & 3,593 & 1,488 & $41 \%$ \\
\hline 324111 & Petroleum Refining & 3,502 & 1,479 & $42 \%$ \\
\hline Other 324 & Other Petroleum and Coal & 91 & 9 & $10 \%$ \\
\hline 331 & Total Primary Metals & 2,186 & 850 & $39 \%$ \\
\hline 331111 & Primary Metals - Iron and Steel & 2,129 & 841 & $40 \%$ \\
\hline 331511 & Primary Metals - Iron Foundries & 44 & 7 & $16 \%$ \\
\hline Other 331 & Primary Metals - Other & 13 & 2 & $15 \%$ \\
\hline 327 & Total Non-Metallic Minerals & 1,173 & 385 & $33 \%$ \\
\hline 3272 & Non-Metallic Minerals - Glass & 340 & 100 & $29 \%$ \\
\hline 327310 & Non-Metallic Minerals - Cement & 665 & 245 & $37 \%$ \\
\hline 327410 & Non-Metallic Minerals - Lime & 148 & 37 & $25 \%$ \\
\hline Other 327 & Non-Metallic Minerals - Other & 20 & 3 & $15 \%$ \\
\hline 486 & Pipeline Transportation & 1,102 & 77 & $7 \%$ \\
\hline 211 & Oil and Gas Extraction & 538 & 73 & $14 \%$ \\
\hline 562 & Waste Management & 113 & 8 & $7 \%$ \\
\hline 325 & Chemical & 92 & 18 & $20 \%$ \\
\hline 212 & Mining, except Oil and Gas & 23 & 2 & $8 \%$ \\
\hline 311 & Food & 8 & 2 & $20 \%$ \\
\hline 322 & Paper & 5 & 0.3 & $6 \%$ \\
\hline 333 & Machinery & 4 & 1 & $25 \%$ \\
\hline 336 & Transportation Equipment & 2 & 0 & $0 \%$ \\
\hline 321 & Wood & 0.5 & 0.01 & $2 \%$ \\
\hline 312 & Beverage and Tobacco & 0.3 & 0 & $0 \%$ \\
\hline 323 & Printing & 0.1 & 0 & $0 \%$ \\
\hline 334 & Computer and Electronic Products & 0.1 & 0.02 & $20 \%$ \\
\hline 611 & Colleges & 0.1 & 0.01 & $4 \%$ \\
\hline 326 & Rubber & 0.03 & 0.01 & $16 \%$ \\
\hline 493 & Warehousing and Storage & $<0.1$ & 0 & $0 \%$ \\
\hline- & Total & 8,840 & 2,904 & $33 \%$ \\
\hline
\end{tabular}


Table 23 presents the expected market penetration by state. Texas has the largest market penetration with $513 \mathrm{MW}$, followed by California with $402 \mathrm{MW}$, and Louisiana with $242 \mathrm{MW}$. An interesting observation is that California has a much higher economic potential (53 percent) compared to Texas (34 percent), primarily due to relatively high electricity prices in California.

Table 23. Expected Market Penetration by State

\begin{tabular}{|c|c|c|c|}
\hline \multirow{2}{*}{ State } & \multirow{2}{*}{$\begin{array}{c}\text { Technical } \\
\text { Potential (MW) }\end{array}$} & \multicolumn{2}{|c|}{ Market Penetration } \\
\cline { 3 - 4 } & $(\mathrm{MW})$ & $(\%)$ \\
\hline TX & 1515.2 & 513.1 & $34 \%$ \\
\hline LA & 883.8 & 241.9 & $27 \%$ \\
\hline CA & 763.4 & 402.3 & $53 \%$ \\
\hline IN & 501.4 & 183.9 & $37 \%$ \\
\hline PA & 482.6 & 179.1 & $37 \%$ \\
\hline IL & 385.6 & 131.8 & $34 \%$ \\
\hline OH & 336.9 & 108.1 & $32 \%$ \\
\hline AL & 293.5 & 89.1 & $30 \%$ \\
\hline KY & 247.6 & 67.9 & $27 \%$ \\
\hline MS & 242.3 & 75.9 & $31 \%$ \\
\hline MI & 196.1 & 61.6 & $31 \%$ \\
\hline OK & 182.5 & 39.0 & $21 \%$ \\
\hline AR & 180.3 & 57.3 & $32 \%$ \\
\hline KS & 176.7 & 45.0 & $25 \%$ \\
\hline WA & 170.3 & 33.7 & $20 \%$ \\
\hline WV & 168.8 & 56.0 & $33 \%$ \\
\hline SC & 160.9 & 56.9 & $35 \%$ \\
\hline MN & 151.7 & 50.3 & $33 \%$ \\
\hline WY & 127.0 & 10.9 & $9 \%$ \\
\hline TN & 121.4 & 36.0 & $30 \%$ \\
\hline NJ & 116.7 & 61.8 & $53 \%$ \\
\hline CO & 108.5 & 27.6 & $25 \%$ \\
\hline IA & 105.1 & 23.7 & $23 \%$ \\
\hline MO & 98.2 & 26.5 & $27 \%$ \\
\hline NC & 90.5 & 26.0 & $29 \%$ \\
\hline
\end{tabular}

\begin{tabular}{|c|c|c|c|}
\hline State & Technical & \multicolumn{2}{|c|}{ Market Penetration } \\
\cline { 3 - 4 } & Potential (MW) & $(\mathrm{MW})$ & $(\%)$ \\
\hline FL & 85.7 & 31.7 & $37 \%$ \\
\hline VA & 84.9 & 21.1 & $25 \%$ \\
\hline NY & 82.6 & 33.8 & $41 \%$ \\
\hline AZ & 78.9 & 13.7 & $17 \%$ \\
\hline UT & 78.8 & 15.9 & $20 \%$ \\
\hline NM & 75.3 & 9.1 & $12 \%$ \\
\hline AK & 72.9 & 37.2 & $51 \%$ \\
\hline WI & 70.1 & 17.7 & $25 \%$ \\
\hline MT & 68.0 & 18.0 & $26 \%$ \\
\hline DE & 60.7 & 30.8 & $51 \%$ \\
\hline NE & 50.8 & 14.6 & $29 \%$ \\
\hline OR & 47.8 & 7.6 & $16 \%$ \\
\hline MD & 44.6 & 20.0 & $45 \%$ \\
\hline GA & 27.6 & 4.3 & $16 \%$ \\
\hline ND & 22.1 & 3.2 & $14 \%$ \\
\hline ID & 19.9 & 0.4 & $2 \%$ \\
\hline SD & 15.1 & 2.8 & $18 \%$ \\
\hline NV & 13.3 & 2.6 & $20 \%$ \\
\hline MA & 10.6 & 3.3 & $31 \%$ \\
\hline ME & 7.6 & 2.2 & $29 \%$ \\
\hline HI & 7.4 & 7.4 & $100 \%$ \\
\hline RI & 3.4 & 0.8 & $23 \%$ \\
\hline CT & 3.1 & 0.8 & $25 \%$ \\
\hline VT & 1.0 & 0.1 & $11 \%$ \\
\hline NH & 0.7 & 0.1 & $19 \%$ \\
\hline Total & 8,840 & 2,904 & $33 \%$ \\
\hline & & & \\
\hline
\end{tabular}




\section{Drivers, Barriers, and Policies}

There are a variety of drivers and barriers to WHP development, which can be grouped into three categories, 1) Technical/Economic, 2) Business, 3) Regulatory. This section describes these drivers and barriers and lays out current and pending policies that serve to promote WHP deployment.

\subsection{Drivers}

\subsubsection{Technical/Economic Drivers}

The emergence of packaged technology, particularly for ORC systems, is improving the cost and performance of these systems. In addition, recent increases in electricity prices are increasing the value of recovering heat from industrial thermal processes, making waste heat to power more attractive. Lower natural gas prices, while favorable for stimulating topping cycle CHP, do not influence the economics for WHP positively and could negatively impact WHP by encouraging systems that burn low cost natural gas over systems that use waste heat.

There are economic benefits for investment in WHP. Facilities typically invest in WHP for energy cost savings, made more feasible by new financial incentives from states, and utilities, as discussed below.

\subsubsection{Business Drivers}

The proliferation of WHP manufacturers and developers is increasing the level of business development investment, which increases the number of customer contacts, site evaluations, and feasibility studies. Increasing the level of business development and marketing will increase the number of projects that ultimately get deployed.

Corporate interest in reducing energy consumption and carbon footprint levels at energy -using facilities is increasing. Corporations are becoming increasingly concerned with their corporate image and achieving recognition of their energy efficiency, renewable energy, and other sustainability efforts.

\subsubsection{Social, Environmental, and Regulatory Drivers}

WHP has social benefits that are starting to be internalized and made part of the private investment decision. WHP systems utilize otherwise wasted thermal energy to produce electricity to either offset on-site consumption or to export to the grid creating an additional revenue stream. WHP represents a significant emissions benefit as a clean energy technology with zero new emissions from the use of waste heat instead of carbon-based fuels. By reducing energy consumed from the grid, WHP reduces 
emissions from fossil fuel generation as well as losses through transmission and distribution.

It has proven difficult to advance the WHP market based only on the site energy bill savings alone when the value of the social benefits is not captured within the project. Social benefits include indirect health benefits from reduced emissions from electricity generation. Other benefits include grid support and reliability, energy efficiency, energy security, new manufacturing jobs, and economic development. More details regarding regulatory drivers that promote these public benefits are discussed in Section 9.3.

\subsection{Barriers}

Barriers to successful implementation of WHP projects include technical issues, business considerations, and regulatory issues.

\subsubsection{Technical/Economic Barriers}

The principal technical hurdle for WHP systems is the heat recovery itself. While the power generation equipment is commercially established and relatively standardized, each heat recovery situation presents unique challenges. Some of the project-specific technical issues that affect project economics include:

- The waste heat sources at a plant are dispersed and difficult to reach or consolidate, or are from non- continuous or batch processes.

- Seasonal operations and low-volume operations reduce the economic benefits of WHP.

- Waste heat sources may contain chemical and/or mechanical contaminants that impact the complexity, cost, and efficiency of the heat recovery process.

- There may be added cost and complexity for integrating the WHP system controls with existing process controls.

- Space limitations and equipment configurations that make WHP systems difficult or impossible to site economically.

- WHP systems may require industrial users to modify their process equipment, potentially triggering permitting issues.

In addition to technical barriers, there are economic barriers to WHP, such as its exclusion from federal investment tax credits and low-interest loans that are available to other clean energy technologies like solar, wind, and topping-cycle CHP. Some states 
have enacted policies to treat WHP as renewable resources, but WHP still lacks access to federal incentives.

\subsubsection{Business Barriers}

As the U.S. recovers from the 2008 economic downturn, many businesses have been reluctant to make investments that do not increase production and revenues. They are especially reluctant to take on projects with perceived risks, such as energy recovery projects that are outside of their core business-a barrier faced by other efficiency technologies as well. These concerns often lead to unrealistically high project hurdle rates for capital-intensive WHP projects. Small projects (less than $\$ 5$ million) can be particularly difficult to develop because the returns are often reduced by the costs of due diligence, permitting, and siting. The economic downturn has exacerbated the inherent risk of financing projects with long paybacks, especially projects dependent on variable electricity rates.

Securing financing from banks for WHP projects is a challenge because the systems can be technically complicated, and they combine the risk associated with power generation with the risk inherent in the primary business operation itself (i.e., there is no heat to recover if the plant shuts down). WHP projects also lack access to certain financial instruments such as Master Limited Partnerships (MLPs) which are regularly used to finance traditional energy projects. Allowing WHP projects to qualify for MLPs could make the projects easier to finance, therefore making them more attractive to a broad range of investors.

There is also a general lack of end-user awareness of WHP technologies and benefits. Few technology demonstrations or case studies currently exist, and most projects are very site and process specific. This leads to the perception that WHP is a new, unproven technology that could potentially jeopardize existing production processes, despite significant potential benefits.

\subsubsection{Regulatory Barriers}

Economic conditions related to equipment costs and forecasted energy savings may be the greatest determinant of whether a WHP project moves forward; however, regulations and policies can have a substantial impact on project economics. For example, standby rates, which determine how much a facility must pay for power from the grid when its onsite generation system experiences a scheduled or emergency outage, may make WHP project economics unfavorable. Additionally, if the power cannot be used on site, projects will require a power purchase agreement with the utility. This is the case with WHP systems on natural gas pipeline compressor stations. While there are currently 12 ORC-based systems operating in the U.S., most of these 
projects are in states with renewable portfolio standards (RPS) or environmental credit systems that recognize waste heat as a renewable or "renewable equivalent" resource. Prices offered for export power are usually low in the absence of some sort of emissions credit system. Because power from WHP systems produces no additional greenhouse gas emissions if supplemental fuel firing is not used industry advocates believe the technology warrants incentives similar to those enjoyed by other clean energy technologies.

\subsection{Public Policies}

\subsubsection{Federal WHP Policy}

At the federal level, WHP is included in a variety of federal policies related to CHP, some related to renewables, and some related to efficiency. These policies are discussed below.

The Federal Energy Regulatory Commission (FERC) adopted "small generator" interconnection standards for distributed energy resources up to $20 \mathrm{MW}$. FERC's standards apply only to facilities subject to the jurisdiction of the commission; these facilities mostly include those that interconnect at the transmission level. FERC's standards generally do not apply to distribution-level interconnection, which is regulated by state public utilities commissions. However, FERC has noted that its interconnection standards for small generators should serve as a useful model for state-level standards. Colorado, Connecticut, North Carolina, Utah, Virginia and Washington's interconnection rules are modeled on FERC interconnection standards for small generators. ${ }^{28}$ These and other statewide interconnection standards reduce the time and simplify the process of interconnecting a WHP system to the electric grid.

In August 2012, President Obama signed Executive Order "Accelerating Investment in Industrial Energy Efficiency". The order sets a national goal of $40 \mathrm{GW}$ of new CHP installations by 2020 , while directing various departments to initiate policies and technical assistance programs to help implement projects. According to the White House, achieving these targets could bring between $\$ 40$ billion and $\$ 80$ billion in new capital investments to the manufacturing sector over the next decade.

President Obama also issued a memorandum titled Federal Leadership on Energy Management, in December 2013.29 The memorandum more than doubles the renewable energy targets for federal agencies and directs federal agencies to update their energy management plans. The December 2013 memorandum does not alter the

${ }^{28}$ Database of State Incentives for Renewables \& Efficiency (DSIRE), 2014.

${ }^{29}$ Web link. 
definition of renewable energy; however, it does add provisions that allow WHP to help meet federal agency targets. "Thermal renewable energy" now can be counted towards targets, which is defined as "energy generated from renewable heat sources, including biomass, solar thermal, geothermal, waste heat, and combined heat and power processes."

There are incentives for certain renewable resources and CHP at the federal level that don't yet apply to WHP but could be expanded to include it, including the following:

- A 30 percent renewable electricity production tax credit (PTC). A production tax credit for renewable energy sources (including wind, biomass, geothermal and hydroelectric systems) was enacted at the Federal level in 1992 and has subsequently been renewed and expanded several times. The tax credit recently expired; it was available to systems that began construction before December 31, 2013. The expansion of the PTC to include WHP systems, and the extension of the PTC beyond its 2013 expiration year would increase the economic viability of WHP projects and provide stability for users and developers by ensuring that the tax credit would still be available when their project begins construction.

- A 10 percent investment tax credit (ITC) is available for CHP systems less than $50 \mathrm{MW}$. The enacting legislation does not explicitly call out WHP as eligible and does not include language that would waive WHP systems from the minimum 60 percent efficiency threshold. As a result, it is not clear if WHP systems can qualify for the credit. See the discussion below regarding draft legislative corrections to the language that have been circulating in Congress.

- The Modified Accelerated Cost Recovery System (MACRS) provides accelerated depreciation of CHP investments, but does not include WHP. The definition of CHP includes the minimum 60 percent efficiency threshold ${ }^{30}$. Both the ITC and the MACRS provide benefits only to for-profit entities subject to the federal income tax.

\footnotetext{
30 The IRS defines CHP as follows - Combined heat and power system property is property that uses the same energy source for the simultaneous or sequential generation of electrical power, mechanical shaft power, or both; in combination with the generation of steam or other forms of useful thermal energy (including heating and cooling applications); the energy efficiency percentage of which exceeds 60 percent; and it produces:

- At least 20 percent of its total useful energy in the form of thermal energy that is not used to produce electrical or mechanical power (or a combination thereof), and

- At least 20 percent of its total useful energy in the form of electrical or mechanical power (or a combination thereof).
} 
The more critical issue from the industry viewpoint may be that WHP projects do not currently qualify for federal tax credits that include CHP or renewable energy. A number of legislative proposals have sought to change this by including WHP projects as eligible under federal tax credits. Other proposed bills would allow for WHP to qualify for loan programs or other federal support, or would extend favorable tax incentives to WHP. Federal policy initiatives that are being proposed to expand policy support for $\mathrm{CHP}$ and other clean energy sources include the following:

- The POWER Act of 2014 would make WHP systems eligible for a 30 percent ITC. ${ }^{31}$

- The Energy Efficiency Tax Incentives Act of 2014 would also make WHP eligible for the 30 percent ITC. WHP would have to be placed into service before January 1,2019 to qualify 32 .

- The Master Limited Partnership Parity Act would extend the tax treatment of publicly traded partnerships as corporations so that "qualifying income" would include income and gains from renewable and alternative fuels including energy from waste heat to power. ${ }^{33}$

- The Local Energy Supply \& Resiliency Act (LESRA) would offer loan guarantees and technical assistance for energy projects, including WHP. ${ }^{34}$

- The State Energy Race to the Top Initiative Act of 2013 would require DOE to establish a voluntary electric and thermal energy productivity challenge grant program to provide support to no more than 25 states for expanding industrial energy efficiency, CHP, and waste heat to power utilization, along with certain other priorities. The grant program would expire in 2030. ${ }^{35}$

\subsubsection{State Policy Trends}

One of the biggest state policy drivers for WHP projects is its inclusion in portfolio standards, whether a renewable portfolio standard (RPS), an energy efficiency resource standard (EERS), or an advanced- energy portfolio standard (APS). Portfolio standards generally require electric utilities and sometimes other retail electric providers to supply a specified minimum amount of retail sales from eligible clean energy resources or efficiency resources. The goal of portfolio standards is to stimulate market and

\footnotetext{
${ }^{31}$ https://www.govtrack.us/congress/bills/113/hr4916

32 http://www.cardin.senate.gov/newsroom/press/release/cardin-feinstein-schatz-legislation-will-boostamerican-jobs-by-promoting-energy-efficieny.

${ }^{33}$ https://www.congress.gov/bill/113th-congress/senate-bill/795

${ }^{34}$ https://www.congress.gov/bill/113th-congress/senate-bill/1205

${ }^{35}$ https://www.govtrack.us/congress/bills/113/s1218
} 
technology development so that, ultimately, clean energy will be economically competitive with conventional forms of electric power. More recently there has been a trend towards explicitly including WHP in portfolio standards.

WHP is known by several terms in portfolio standards including waste heat recovery, waste energy recovery, recycled energy, industrial cogeneration, a qualified energy recovery process, waste gas and waste heat capture, a resource that makes efficient use of waste heat, and industrial by-product technologies. Currently, nine of 29 states with binding RPS include WHP as an eligible resource (i.e., Colorado, Connecticut, Hawaii, Michigan, Nevada, North Carolina, Ohio, Pennsylvania, and West Virginia)), ${ }^{36}$ while six states with nonbinding renewable energy goals include WHP in some fashion (i.e., Indiana, Louisiana [pilot program],Oklahoma, North Dakota, South Dakota, and Utah). States that include WHP as part of their stand-alone EERS targets include Delaware, and Minnesota. ${ }^{37}$ An example of a state that has included WHP in its portfolio standards is Connecticut. The state first established the standard in 1998 and has amended the standard several times over the years. In 2006, the state set targets for Class III resources which includes "systems that recover waste heat or pressure from commercial and industrial processes installed on or after April 1, 2007.38" A list of other states that explicitly call out WHP as eligible under their RPS/EERS/APS is as follows:

\section{State RPS/EERS/APS Programs that Include WHP}

Colorado - has a RPS that includes WHP as an eligible technology. Under the RPS, WHP is defined as "recycled energy" and is defined as "energy produced by a generation unit with a nameplate capacity of not more than 15 megawatts (MW) that converts the otherwise lost energy from the heat from exhaust stacks or pipes to electricity and that does not combust additional fossil fuel." 39

Connecticut (see above) - under Class III of the state's RPS, systems that produce electrical or thermal energy from recovered waste heat or pressure from commercial and industrial processes installed on or after April 1, 2007, qualify for credit.

Delaware - under the state's EERS, the use of "recycled energy" may also count as a source of energy savings. "Recycled energy savings" is defined as a reduction in electricity or natural gas consumption that results from a modification of an industrial or

\footnotetext{
${ }^{36}$ http://www.ferc.gov/market-oversight/othr-mkts/renew/othr-rnw-rps.pdf.

${ }^{37} \mathrm{http}: / / \mathrm{www}$. epa.gov/chp/documents/ps paper.pdf.

${ }^{38} \mathrm{http}: / /$ www.ct.gov/pura/cwp/view.asp?a=3354\&q=415186.

${ }^{39} \mathrm{http}: / /$ www.dsireusa.org/incentives/incentive.cfm?Incentive Code=CO24R
} 
commercial system that commenced operation before July 29, 2009, in order to make productive use of electrical, mechanical, or thermal energy that would otherwise be wasted. 40

Hawaii - the state's portfolio standard allows a limited number of WHP projects to qualify if the waste heat is from CHP. Renewable Electrical Energy defined as "electric energy savings brought about by the use of rejected heat from cogeneration and combined heat and power systems ${ }^{41}$ " qualifies under the portfolio standard. The standard excludes "fossil-fueled qualifying facilities that sell electricity to electric utility companies and central station power projects," so only a very limited number of WHP projects may qualify. In 2015, Hawaii's Energy Efficiency Portfolio Standard (EEPS)/EERS will begin. Electrical energy savings from energy efficiency technologies such as WHP will likely qualify under the EERS. ${ }^{42}$

Indiana - the state's RPS goal includes "industrial byproduct technologies that use fuel or energy that is a byproduct of an industrial process; "and "waste heat recovery from capturing and reusing the waste heat in industrial processes for heating or for generating mechanical or electrical work" as eligible. ${ }^{43}$

Louisiana - the state's RPS pilot program includes "waste heat recovery" as eligible. However, in August 2013, the state concluded this program. ${ }^{44}$

Maine - under the state's RPS, eligible CHP and small power producers include those that use waste heat recovery.

Michigan - under the state's RPS certain types of industrial WHP facilities are eligible and defined as "a facility that generates electricity using industrial thermal energy or industrial waste energy." 45

Minnesota - under the state's EERS, waste heat recovery (converted into electricity) may count toward the energy savings goal.

Nevada - under the state's RPS, WHP defined as "energy recovery processes" is eligible. Energy recovery processes are "electricity generating systems with a

\footnotetext{
${ }^{40}$ http://delcode.delaware.gov/title26/c015/index.shtml .

${ }^{41}$ http://www.capitol.hawaii.gov/hrscurrent/Vol05 Ch0261-0319/HRS0269/HRS 0269-0091.HTM.

42 http://www.dsireusa.org/incentives/incentive.cfm? Incentive Code=HI15R\&re=0\&ee $=0$

${ }^{43} \mathrm{http} / / / \mathrm{www}$.dsireusa.org/incentives/incentive.cfm? Incentive Code $=$ IN12R\&re $=0 \& e e=0$

${ }^{44} \mathrm{http}: / /$ www.dsireusa.org/incentives/incentive.cfm? Incentive Code=LA10R

${ }^{45}$ http://www.michigan.gov/documents/mpsc/2007-SNB-0213 254495 7.pdf
} 
nameplate capacity of 15 megawatts or less that convert the otherwise lost energy from the heat from exhaust stacks or pipes used for engines or manufacturing or industrial processes; or the reduction of high pressure in water or gas pipelines before the distribution of the water or gas." To qualify, the system cannot use additional fossil fuel or require a combustion process to generate the electricity. ${ }^{46}$

North Carolina - the state's RPS allows for CHP which uses waste heat derived from eligible renewable resources to qualify. Also, up to 25 percent of the requirement may be met through energy efficiency technologies, including CHP systems powered by nonrenewable fuels.

North Dakota - WHP defined as "recycled energy systems" qualify under the state's RPS goal. Recycled energy systems must generate electricity from currently unused waste heat resulting from combustion or other processes and must not use an additional combustion process. The term "recycled energy system" does not include waste heat captured from any system designed primarily to generate electricity unless the generation system consumes wellhead gas that would otherwise be flared, vented or wasted. ${ }^{47}$

Ohio - WHP qualifies as renewable under the state's Alternative Energy Portfolio Standard and as energy efficiency under the state EERS, but each WHP project can only receive credit under one standard. In May 2014, Ohio passed legislation freezing the AEPS at current levels until 2017, and allowing utilities to opt out of the EERS ${ }^{48}$. Under the current regulations, WHP is referred to as "waste energy recovery." A "waste energy recovery system" means a facility that generates electricity through the conversion of energy from either of the following:

- Exhaust heat from engines or manufacturing, industrial, commercial, or institutional sites, except for exhaust heat from a facility whose primary purpose is the generation of electricity;

- Reduction of pressure in gas pipelines before gas is distributed through the pipeline, provided that the conversion of energy to electricity is achieved without using additional fossil fuels.

Oklahoma - WHP qualifies under the state's RPS goal. Up to 25 percent of the renewable energy goal can be met with demand side management (DSM) and energy efficiency. WHP qualifies as a DSM measure. DSM includes "industrial by-product

\footnotetext{
${ }^{46} \mathrm{http}: / /$ www.dsireusa.org/incentives/incentive.cfm? Incentive_Code=NV01R\&re=0\&ee $=0$

$47 \mathrm{http}: / /$ www.dsireusa.org/incentives/incentive.cfm ? Incentive_Code $=$ ND04R\&re $=0 \&$ ee $=0$

${ }^{48} \mathrm{http}: / /$ www.sustainablebusiness.com/index.cfm/go/news.display/id/25739.
} 
technologies consisting of the use of a by-product from an industrial process, including the reuse of energy from exhaust gases or other manufacturing by-products that are used in the direct production of electricity at the facility of a customer. ${ }^{49}$

Pennsylvania - the state's Alternative Energy Portfolio Standard (AEPS) allows for WHP to qualify as a Tier II resource. Tier II resources include new and existing demandside management and distributed generation systems, including WHP.

South Dakota - the state's Renewable, Recycled and Conserved Energy Objective (i.e., RPS goal) allows for electricity produced from waste heat to qualify.

Utah - the state's RPS goal allows for waste gas and waste heat capture or a recovery system to qualify.

West Virginia - under the state's Alternative and Renewable Energy Portfolio Standard, WHP, defined as "recycled energy," is eligible. Recycled energy means "useful thermal, mechanical or electrical energy produced from: (i) Exhaust heat from any commercial or industrial process; (ii) waste gas, waste fuel or other forms of energy that would otherwise be flared, incinerated, disposed of or vented; and (iii) electricity or equivalent mechanical energy extracted from a pressure drop in any gas, excluding any pressure drop to a condenser that subsequently vents the resulting heat." 50

\section{Other State Incentives for WHP}

Seven states - California, Colorado, Connecticut, North Carolina, Oregon, South Dakota and Utah - provide additional incentives, other than those under portfolio standards, to encourage the development of WHP resources. Advocates often state that these incentives will help boost the competitiveness of WHP in the marketplace, especially when compared with traditional resources such as low priced coal and natural gas, and subsidized renewables. ${ }^{51}$ State incentives for WHP are listed below. A number of electric and gas utilities also offer WHP incentives to customers within their service territories, either as part of efficiency programs, renewable programs, or CHP programs

\footnotetext{
${ }^{49}$ http://www.oscn.net/applications/oscn/DeliverDocument.asp?CitelD=459327.

$50 \mathrm{http}: / /$ www.legis.state.wv.us/WVCODE/ChapterEntire.cfm?chap=24\&art=2F

${ }^{51} \mathrm{http}$ ://www.heatispower.org/wp-content/uploads/2013/04/Ohio-Senate-Public-Utility-Committeetestimony-with-attachments-4 22 13.pdf
} 
California - The state's Self Generation Incentive Program (SGIP), a rebate program, provides an incentive of $\$ 1.13 / \mathrm{W}$ for WHP projects. ${ }^{52}$

Colorado - the state's net metering rules require municipal utilities and cooperatives to allow "recycled energy" to qualify, but only for systems up to $25 \mathrm{~kW}$.

Connecticut -the state's net metering rules allow for virtual net metering for state, municipal, and agricultural customers. A virtual net metering facility must generate electricity using either Class I or Class III resources from facilities of up to $3 \mathrm{MW}$; WHP qualifies as a Class III resource. Under the state's net metering provisions, net excess generation is carried over as a kWh credit for one year and reimbursed to customer at the avoided cost of wholesale power at the end of the year.

Illinois - the state's Department of Commerce and Economic Opportunity (DCEO) CHP Pilot Program includes WHP. The program targets local governments, municipal corporations, public school districts, community college districts, public universities, and state/federal facilities located in the service territories of Commonwealth Edison, Ameren Illinois, Nicor Gas, Peoples Gas, and/or North Shore Gas. The program provides different incentives for different stages of the project: ${ }^{33}$

- Design Incentive: $\$ 75 / \mathrm{kW}$ capacity (following completion of the design phase)

- Constructive Incentive: $\$ 175 / \mathrm{kW}$ capacity (following successful commissioning of the system)

- Production Incentive: $\$ 0.08 / \mathrm{kWh}$ ( $\eta \geq 70$ percent HHV) or $\$ 0.06 / \mathrm{kWh}$ (60 percent $\leq \eta<70$ percent HHV) of "useful electric energy" produced (after 12 months of operation based on meeting the measured operating requirements of the system)

New Mexico - WHP projects qualify for an advanced energy income tax credit of up to six percent of the system's costs.

North Carolina -the state allows net metering rules for WHP systems up to $1 \mathrm{MW}$, as long as the waste heat is derived from a renewable resource.

Oregon - the state's Small-Scale Energy Loan Program provides low-interest loans for energy produced from renewable resources such as waste heat.

52 http://www.cpuc.ca.gov/NR/rdonlyres/D138BD29-2B31-4082-B963-

2943114F5B68/0/2014 SGIPHandbook V1.pdf

${ }^{53}$ http://www.erc.uic.edu/energy-efficiency/illinois-energy-now-programs/dceo-chp-pilot-program 
South Dakota - the state's Renewable Energy Facility Sales and Use Tax Reimbursement program allows for electricity produced from waste heat to qualify for a tax incentive of up to 100 percent of the tax paid on project costs. To qualify, the project costs associated with a new or expanded facility must exceed $\$ 20$ million, and the costs associated with equipment upgrades must exceed $\$ 2$ million.

Utah - Utah has a number of additional incentives and policies that encourage WHP. In addition to the state's renewable portfolio goal, waste heat capture or recovery also qualifies under the state's interconnection standards and as well as under the state's net metering standards. Interconnection and net metering rules apply to IOUs and electric cooperatives in the state. Systems up to $20 \mathrm{MW}$ are allowed to interconnect, and non-residential systems up to $2 \mathrm{MW}$ in size and residential systems up to $25 \mathrm{~kW}$ are allowed to net meter. As of 2014, WHP systems are eligible for the same state tax credits as solar, wind, and other renewables. ${ }^{54}$

Utah also has an innovative policy known as "SB 12" that allows large energy users to contract for offsite, remotely-located renewables (including WHP) greater than $2 \mathrm{MW}$ and receive the same cost-savings and environmental benefits as if the system was onsite, including demand and energy savings on their monthly bill and renewable energy credits (RECs). The end user just pays the utility a delivery charge. ${ }^{55}$

${ }^{54}$ http://www.dsireusa.org/incentives/incentive.cfm?Incentive Code $=U T 32 F \&$ re $=0 \&$ ee $=0$

55 http://le.utah.gov/ 2012/bills/sbillenr/sb0012.pdf 


\section{References}

BCS, 2006. Engineering Scoping Study of Thermoelectric Generator Packages for Industrial Waste Heat Recovery, BCS, Incorporated.

CEATI 2012. Conversion of Waste Heat to Electricity: Technology Update and Assessment of Potential Applications, prepared by Hatch and ICF Marbek, prepared for CEATI International.

DOE, 2000. Energy and Environmental Profile of the U.S. Chemical Industry, prepared by Energetics Inc. prepared for U.S. Department of Energy, Office of Industrial Technologies.

DOE, 2008. Waste Heat Recovery: Technology and Opportunities in U.S. Industry, prepared by BCS Inc., prepared for U.S. Department of Energy, Industrial Technologies Program.

DOE, 2010. Waste Heat Recovery for Power and Heat Workshop, sponsored by U.S. Department of Energy, Clean Energy Application Centers, Chicago, Illinois.

Echogen, 2012. Waste Heat to Power (WH2P) Applications Using a Supercritical $\mathrm{CO}_{2-}$ Based Power Cycle, presented at Power-Gen International.

EPA, 2012. Waste Heat to Power Systems, U.S. Environmental Protection Agency, http://www.epa.gov/chp/documents/waste heat power.pdf .

Graymont, 2009. New Kiln Gives Back Power, Grayzette, Vol. 5, No. 2, Graymont Ltd., Richmond, British Columbia.

INGAA, 2008. Waste Energy Recovery Opportunities for Interstate Natural Gas Pipelines, Interstate Natural Gas Association of America.

ICF, 2013. CHP Installation Database, maintained by ICF International for Oak Ridge National Laboratory, http://www.eea-inc.com/chpdata/index.html .

IFC, 2014. Waste Heat Recovery for the Cement Sector: Market and Supplier Analysis, prepared by Institute for Industrial Productivity, prepared for International Finance Corporation.

LBNL, 2005. Clean Energy Technologies: A Preliminary Inventory of the Potential for Electricity Generation, Lawrence Berkeley National Laboratory. 
NCSU, 2013. Database of State Incentives for Renewables and Efficiency, North Carolina Solar Center at North Carolina State University, www.dsireusa.org.

ORNL, 2004. An Inventory of Industrial Waste Heat and Opportunities for Thermally Activated Technologies, prepared by United Technologies Research Center, prepared for Oak Ridge National Laboratory.

PNNL, 2006. Opportunity Analysis for Recovering Energy from Industrial Waste Heat and Emissions, Pacific Northwest National Laboratory.

PURPA, 1978. Definitions related to Qualifying Cogeneration and Small Power Production Facilities, http://www.gpo.gov/fdsys/pkg/CFR-2012-title18-vol1/pdf/CFR2012-title18-vol1-part292.pdf .

Primen, 2003. Converting Distributed Energy Prospects Into Customers: Primen's 2003 Distributed Energy Market Study, Boulder, Colorado.

Siada, Ray et al., 2010. Presentation to CPUC on Implementation of SB 412, Guardian Industries, Waste Heat Solutions, TAS Energy.

TESPL, 2010. Cement Plant Case Studies, Transparent Energy Systems Private Ltd., http://www.heatrecovery-system.com/case-study-1-cement-plant.

Thekdi, 2007. Waste Heat to Power: Economic Tradeoffs and Considerations, Arvind Thekdi, $3^{\text {rd }}$ Annual Waste Heat to Power Workshop, Houston, Texas.

WSU, 2009. An Overview of Industrial Waste Heat Recovery Technologies for Moderate Temperatures Less Than $1000^{\circ} \mathrm{F}$, Northwest CHP Application Center, WSUEEP09-26, http://www.chpcenternw.org/NwChpDocs/AnOverviewOfIndustrialWasteHeatRecoveryT echForModerateTemps.pdf .

White House, 2012. Accelerating Investment in Industrial Energy Efficiency, Executive Order 13624, http://www.gpo.gov/fdsys/pkg/FR-2012-09-05/pdf/2012-22030.pdf . 


\section{Appendix A. Technical and Economic Potential Methodologies}

This appendix describes the methodologies used to calculate the technical and economic potential values for waste heat temperature greater than $450^{\circ} \mathrm{F}$.

\section{$\underline{\text { Technical Potential }}$}

This section describes the approach used to estimate the technical potential of WHP.

\section{Industrial Waste Heat Sites}

To identify the industrial waste heat sites, ICF used a number of databases:

- EPA Greenhouse Gas Reporting Program (EPA GHGRP) database

- Oil and Gas Journal's Gas Processing Plants database

- Oil and Gas Journal's Refinery Survey

- Portland Cement Association's Cement Kilns database

- Association of Iron and Steel Engineer's Directory of Iron and Steel Plants

\section{EPA GHGRP}

The EPA GHGRP database contains the following information used in the analysis:

- Facility name and zip code

- Process name and process type

- Fuel input capacity (MMBtu/hour) and annual fuel consumption (MMBtu/year)

- Annual $\mathrm{CO}_{2}$ emissions

- Fuel type and GHG emissions factor (kg/MMBtu).

ICF developed a methodology to use these data in the estimation of WHP potential.

- The EPA data for boilers and for power plants were removed from the data set because boilers and power plants were not considered to be viable candidates due to stack gas temperatures typically below $450^{\circ} \mathrm{F}$. Table 24 shows the stack gas temperatures that were assumed for different types of equipment. 
Table 24. Assumed Stack Gas Temperatures by Equipment Type

\begin{tabular}{|c|c|}
\hline Equipment & Temperature $\left({ }^{\circ} \mathrm{F}\right)$ \\
\hline Calciner, Kilns & 700 \\
\hline Flare & 1200 \\
\hline Incinerator & 1400 \\
\hline Oven & 700 \\
\hline Reciprocating Engine & 800 \\
\hline Regenerative Oxidizer & 1,200 \\
\hline Thermal Oxidizer & 1,200 \\
\hline
\end{tabular}

- Estimates for combustion products by fuel type were derived using estimates for $\mathrm{CO}_{2}$ percentage by weight at 3 percent oxygen. The EPA reported $\mathrm{CO}_{2}$ equivalent $\left(\mathrm{CO}_{2} \mathrm{e}\right)$ emissions were divided by the appropriate $\mathrm{CO}_{2}$ percentage to provide an estimate of total emissions. This estimate was divided by the estimated equivalent full load hours (EFLH) to determine the pounds per hour of stack gas emissions.

- The energy content of these stack gas emissions were estimated based on the difference between the assumed process stack gas temperature and a minimum stack gas temperature of $250{ }^{\circ} \mathrm{F}$ using an average specific heat for the combustion products of $0.26 \mathrm{Btu} / \mathrm{lb}$.

- The ideal (Carnot) efficiency of a potential WHP system was estimated using the assumed stack gas temperature as the heat source and a cooling tower $\left(85^{\circ} \mathrm{F}\right)$ as the heat sink.

- A typical Rankine cycle efficiency was estimated at 40 percent of the Carnot efficiency to estimate the electric generation capacity for the process.

- The estimated WHP capacity was filtered so that the only systems that were counted had a starting stack gas temperature of least $500^{\circ} \mathrm{F}$, and minimum estimated electric capacity of at least $100 \mathrm{~kW}$.

- Some of the EFLH calculations from the EPA data were over 8,760 hours/year. The causes for these occurrences were not clear. For these cases, the hourly capacity was adjusted to get an EFLH to 8,760 hours.

\section{Oil and Gas Journal's Gas Processing Database}

The Oil and Gas Journal's gas processing database was used to identify the gas processing facilities. The database reports the gas processing capacity of each facility (in million cubic feet/day (MMcfd)). To estimate the WHP technical potential capacity (in kW) for each facility, an existing WHP installation's characterization was used (a gas 
processing facility in Neptune, LA with a capacity of 650 MMcfd, reported a 4.5 MW project).

\section{Oil and Gas Journal's Gas Refinery Survey}

The Oil and Gas Journal's refinery survey was used to identify refineries in the U.S. The survey provides capacity by type of process in each refinery. To estimate the WHP technical potential capacity (in $\mathrm{kW}$ ) for each refinery, the potential for each major process was calculated first based on the approach used for the EPA GHGRP. ICF used appropriate waste heat temperature per process. Then the potential by process was added for the total potential for each refinery. Table 25 presents the stack gas temperature assumptions for each refining process.

Table 25. Assumed Stack Gas Temperatures by Refining Process

\begin{tabular}{|l|c|}
\hline Process & Temperature $\left({ }^{\circ} \mathrm{F}\right)$ \\
\hline Crude Distillation & 316 \\
\hline Vacuum Distillation & 421 \\
\hline Coking & 800 \\
\hline Thermal Cracking & 800 \\
\hline Visbreaking & 800 \\
\hline Catalytic Cracking & 1,148 \\
\hline Catalytic Reforming & 900 \\
\hline Hydrocracking & 800 \\
\hline Desulfurization & 968 \\
\hline Alkylation & 800 \\
\hline Coke Production & 1,000 \\
\hline Steam Methane Reforming & 1,500 \\
\hline
\end{tabular}

\section{Portland Cement Association's Cement Kilns Database}

The Portland Cement Association's Cement kilns database was used to identify the cement kilns and plants in the U.S. The database shows the type of kiln (e.g., dry, wet, preheater/precalciner, etc.) and capacity in each cement plant. To estimate the WHP technical potential capacity (in kW) for each cement plant, the potential for each kiln was calculated first based on the approach used for the EPA GHGRP. ICF used appropriate waste heat temperature given the type of kiln. Then the potential by kiln was added for the total potential for each cement plant. Table 26 shows the exhaust temperature assumptions by kiln type. 
Table 26. Assumed Exhaust Temperatures by Kiln Type

\begin{tabular}{|l|c|}
\hline Type of Kiln & Temperature $\left({ }^{\circ} \mathrm{F}\right)$ \\
\hline Dry & 840 \\
\hline Dry/Precalciner & 640 \\
\hline Dry/Preheater & 640 \\
\hline Wet & 640 \\
\hline
\end{tabular}

\section{Association of Iron and Steel Engineers' Directory of Iron and Steel plants}

The Association of Iron and Steel Engineers' Directory of Iron and Steel Plants was used to identify iron and steel plants. The database includes the capacity by major process in each facility. To estimate the WHP technical potential capacity (in kW) for each process, latest studies and assessments of WHP in the iron and steel industry were used. For example, according to a Metal Bulletin report in 2012, an EAF facility with 150 tons per hour of steel capacity could power $29 \mathrm{MW}$ with the waste heat from the facility.

\section{Natural Gas Compressor Stations}

For compressor stations, ICF used the 2008 compression stations database from EIA. The method to calculate the WHP technical potential capacity is similar to the one used for the EPA GHGRP. For the calculations, exhaust temperature was assumed to be 800 ${ }^{0} \mathrm{~F}$, and load factor was 8,760 hours. It is noted that WHP installations in compressor stations are all ORC, which is better used at lower than the given exhaust temperature of $800{ }^{\circ} \mathrm{F}$. However, due to other reasons, including its more compact size, lower operating costs (unlike steam systems, ORC does not need a licensed steam operator, which some states require) and applicability for remote locations, ORCs have become the preferred system. ${ }^{56}$

\section{Landfill Gas Flares}

For landfill gas flares, ICF used EPA's Landfill Methane Outreach Program (LMOP) database to identify the landfill facilities that use reciprocating engines to generate electricity. To estimate the WHP technical potential capacity (in kW) for each facility, an existing WHP installation's characterization was used (a landfill facility with an ORC capacity of $125 \mathrm{~kW}$, capturing exhaust heat from reciprocating engines generating 1.4 MW of electricity).

\footnotetext{
${ }^{56}$ Waste Energy Recovery Opportunities for Interstate Natural Gas Pipelines, prepared for Interstate Natural Gas Association of America, February 2008.
} 


\section{Oil and Gas Flares}

ICF has worked with major oil and gas wells databases. These databases identify all the oil and gas wells in the U.S. However, none of the databases reported if the well flared or marketed the associated gas. ICF needed to identify those wells that flare the associated gas. Because of the lack of data on this, ICF was not able to estimate the technical potential capacity of oil and gas flaring.

\section{Economic Potential and Market Penetration}

The economic potential calculation begins with a simple payback calculation. The annual cost of operating the WHP system is compared to the avoided electric costs, allowing the number of years it would take for this annual savings to repay the initial capital investment to be calculated. Using a simple payback calculation is a very common form of screening to identify potentially economic investments of any type, and it is used by facility operators and technology developers in the early stages of identifying economic WHP projects.

The annual savings calculation consists of the following components:

- WHP operating cost (on a per kW basis) is a function of the assumed equivalent full load hours of operation per year. Fuel cost is zero as the fuel source is waste energy.

- Avoided electric cost is a function of the WHP hours of operation and the avoided WHP electric costs.

The payback period is calculated for each competing technology in the size bin. The WHP technology with the lowest payback period is assumed to define the market acceptance rate. Because of the lack of information on the acceptance rate of WHP technology, the acceptance rate based on a survey of business facilities that could potentially implement CHP was used. For the economic potential of this study, it is assumed that the results from this study are applicable to the entire country. Figure $\mathbf{1 6}$ shows the percentage of customers that would accept a given payback period and move forward with a CHP investment based on survey results. As can be seen from the figure, more than 30 percent of customers would reject a project that promised to return their initial investment in just one year. A little more than half would reject a project with a payback of 2 years. This type of payback translates into a project with an $\mathrm{ROI}$ of between $49-100$ percent. 
Figure 16. Sample Market Acceptance Survey Results

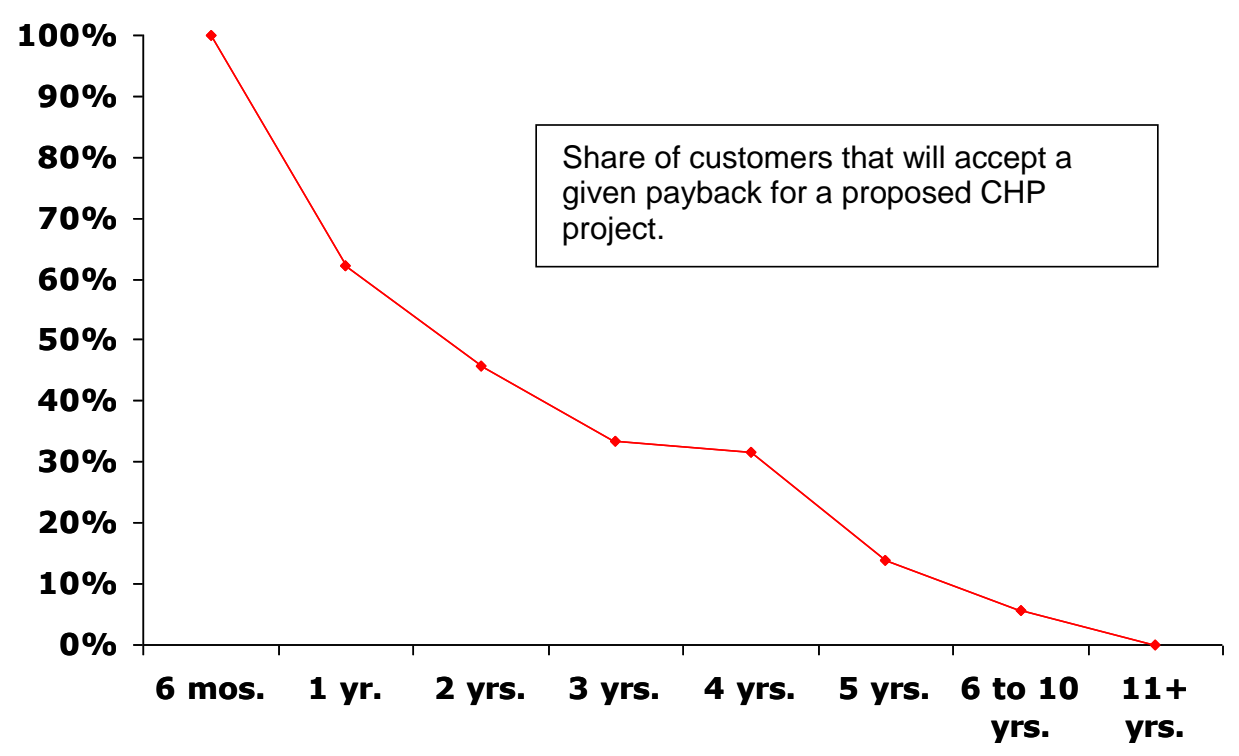

Source: Primen, 2003

This acceptance curve is used to determine the share of the technical potential in each utility and size market segment that will go forward with WHP based on the calculated payback for that market segment. As indicated, the low acceptance levels for payback periods above 5 years imply a very high risk perception on the part of potential WHP project implementers.

Potential explanations for rejecting a project with such high returns is that the average customer does not believe that the results are real and is protecting himself from this perceived risk by requiring very high projected returns before a project would be accepted, or that the facility is very capital limited and is rationing its capital-raising capability for higher priority projects (market expansion, product improvement, and so forth.). Arguments can be made that these acceptance rates should be higher, but they are used in the model to reflect actual expected customer behavior in the absence of any change in perceptions regarding the risk of investing in WHP. 


\section{Appendix B. Technical Potential Data \\ (waste heat temperatures $>450^{\circ} \mathrm{F}$ )}

Table 27. Waste Heat to Power Technical Potential

(number of sites by state)

\begin{tabular}{|c|c|c|}
\hline State & No. of Sites & Share \\
\hline TX & 417 & $14.2 \%$ \\
\hline LA & 202 & $6.9 \%$ \\
\hline PA & 192 & $6.5 \%$ \\
\hline CA & 137 & $4.7 \%$ \\
\hline OK & 114 & $3.9 \%$ \\
\hline WY & 112 & $3.8 \%$ \\
\hline KS & 110 & $3.7 \%$ \\
\hline MI & 106 & $3.6 \%$ \\
\hline IL & 89 & $3.0 \%$ \\
\hline NY & 87 & $3.0 \%$ \\
\hline IN & 74 & $2.5 \%$ \\
\hline NM & 73 & $2.5 \%$ \\
\hline OH & 72 & $2.4 \%$ \\
\hline AL & 70 & $2.4 \%$ \\
\hline CO & 70 & $2.4 \%$ \\
\hline WI & 60 & $2.0 \%$ \\
\hline WV & 58 & $2.0 \%$ \\
\hline MS & 56 & $1.9 \%$ \\
\hline TN & 56 & $1.9 \%$ \\
\hline KY & 55 & $1.9 \%$ \\
\hline VA & 52 & $1.8 \%$ \\
\hline AZ & 50 & $1.7 \%$ \\
\hline FL & 49 & $1.7 \%$ \\
\hline WA & 42 & $1.4 \%$ \\
\hline UT & 42 & $1.4 \%$ \\
\hline & & \\
\hline
\end{tabular}

\begin{tabular}{|c|c|c|}
\hline State & No. of Sites & Share \\
\hline AR & 41 & $1.4 \%$ \\
\hline MN & 40 & $1.4 \%$ \\
\hline NJ & 39 & $1.3 \%$ \\
\hline IA & 36 & $1.2 \%$ \\
\hline MA & 35 & $1.2 \%$ \\
\hline MO & 34 & $1.2 \%$ \\
\hline NE & 33 & $1.1 \%$ \\
\hline NC & 26 & $0.9 \%$ \\
\hline MT & 25 & $0.8 \%$ \\
\hline OR & 25 & $0.8 \%$ \\
\hline GA & 24 & $0.8 \%$ \\
\hline SC & 21 & $0.7 \%$ \\
\hline ND & 21 & $0.7 \%$ \\
\hline ID & 17 & $0.6 \%$ \\
\hline MD & 16 & $0.5 \%$ \\
\hline NV & 11 & $0.4 \%$ \\
\hline CT & 9 & $0.3 \%$ \\
\hline RI & 8 & $0.3 \%$ \\
\hline SD & 8 & $0.3 \%$ \\
\hline ME & 7 & $0.2 \%$ \\
\hline AK & 7 & $0.2 \%$ \\
\hline VT & 6 & $0.2 \%$ \\
\hline DE & 5 & $0.2 \%$ \\
\hline NH & 5 & $0.2 \%$ \\
\hline HI & 2 & $0.1 \%$ \\
\hline Total & 2,946 & $100 \%$ \\
\hline & & \\
\hline & & \\
\hline
\end{tabular}




\section{Appendix C. Development of Waste Heat Inventory Data}

This appendix describes the methodology used to develop waste heat inventory data for the manufacturing sector. The analysis of WHP potential begins with quantifying the amount of waste heat available. ICF used data primarily from two reports to develop this this information:

- ORNL 2004, An Inventory of Industrial Waste Heat and Opportunities for Thermally Activated Technologies

- DOE 2008, Waste Heat Recovery: Technology and Opportunities in U.S. Industry

The ORNL 2004 data were based on two approaches. The first approach examined 108 industrial processes based on a study "Energy Analysis of 108 Industrial Processes". ${ }^{57}$ The data in this study are dated as the estimates were based on conditions in the late 1970's. A second approach used exhaust stream flow and temperature data from EPA's 2001 National Emissions Inventory (NEI). Based on the more current information in the $\mathrm{NEI}$ approach, it was deemed that the results of the NEI approach are more appropriate for this study. The NEI approach produced results using two reference temperatures $\left(60^{\circ} \mathrm{F}\right.$ and $\left.300^{\circ} \mathrm{F}\right)$, and included a breakdown by 3-digit NAICS code and by temperature range. The ORNL 2004 presented the results only graphically. As such, the numerical values were estimated after visually assessing the figures. Table 28 shows the estimates of waste heat by NAICS code and temperature range for a reference temperature $60^{\circ} \mathrm{F}$.

${ }^{57}$ Brown, H.L., B.B. Hamel, and B.A. Hedman, 1996, Energy Analysis of 108 Industrial Processes. 
Table 28. ORNL 2004 Waste Heat Inventory by NAICS Code and Temperature Range $\left({ }^{\circ} \mathrm{F}\right)$

\begin{tabular}{|c|c|c|c|c|c|c|c|c|c|c|c|c|c|c|c|c|c|c|c|}
\hline Manufacturing Sector & $<100$ & $\begin{array}{l}100- \\
200\end{array}$ & $\begin{array}{l}200- \\
300\end{array}$ & $\begin{array}{l}300- \\
400\end{array}$ & $\begin{array}{l}400- \\
500\end{array}$ & $\begin{array}{l}500- \\
600\end{array}$ & $\begin{array}{l}600- \\
700\end{array}$ & $\begin{array}{l}700- \\
800\end{array}$ & $\begin{array}{l}800- \\
900\end{array}$ & $\begin{array}{l}900- \\
1000\end{array}$ & $\begin{array}{l}1000- \\
1100\end{array}$ & $\begin{array}{l}1100- \\
1200\end{array}$ & $\begin{array}{l}1200- \\
1300\end{array}$ & $\begin{array}{l}1300- \\
1400\end{array}$ & $\begin{array}{l}1400- \\
1500\end{array}$ & $\begin{array}{l}1500- \\
1600\end{array}$ & $\begin{array}{l}1600- \\
1700\end{array}$ & $\begin{array}{l}1700- \\
1800\end{array}$ & Total \\
\hline 311: Food Manufacturing & 0.3 & 2.4 & 4.3 & 8.0 & 26.0 & 1.3 & 20.1 & 0.0 & 0.0 & 0.0 & 0.0 & 0.0 & 0.0 & 0.0 & 0.0 & 0.0 & 0.0 & 0.0 & 62.4 \\
\hline $\begin{array}{l}\text { 312: Beverage and Tobacco } \\
\text { Product Manufacturing }\end{array}$ & 0.1 & 0.3 & 0.2 & 1.6 & 0.4 & 0.0 & 0.2 & 0.0 & 0.0 & 0.0 & 0.0 & 0.0 & 0.0 & 0.0 & 0.0 & 0.0 & 0.0 & 0.0 & 2.8 \\
\hline 313: Textile Mills & 0.8 & 13.5 & 8.5 & 1.3 & 1.0 & 0.3 & 0.2 & 0.0 & 0.0 & 0.0 & 0.0 & 0.0 & 0.0 & 0.0 & 0.0 & 0.0 & 0.0 & 0.0 & 25.6 \\
\hline 314: Textile Product Mills & 0.0 & 0.0 & 0.0 & 0.0 & 0.0 & 0.0 & 0.0 & 0.0 & 0.0 & 0.0 & 0.0 & 0.0 & 0.0 & 0.0 & 0.0 & 0.0 & 0.0 & 0.0 & 0.0 \\
\hline 315: Apparel Manufacturing & 0.0 & 3.1 & 0.1 & 0.0 & 0.0 & 0.0 & 0.0 & 0.0 & 0.0 & 0.0 & 0.0 & 0.0 & 0.0 & 0.0 & 0.0 & 0.0 & 0.0 & 0.0 & 3.2 \\
\hline $\begin{array}{l}\text { 316: Leather and Allied } \\
\text { Product Manufacturing }\end{array}$ & 0.0 & 0.0 & 0.0 & 0.0 & 0.0 & 0.0 & 0.0 & 0.0 & 0.0 & 0.0 & 0.0 & 0.0 & 0.0 & 0.0 & 0.0 & 0.0 & 0.0 & 0.0 & 0.0 \\
\hline $\begin{array}{l}\text { 321: Wood Product } \\
\text { Manufacturing }\end{array}$ & 5.6 & 38.0 & 49.9 & 46.0 & 7.5 & 4.5 & 0.5 & 0.0 & 0.0 & 0.0 & 0.0 & 0.0 & 0.0 & 0.0 & 0.0 & 0.0 & 0.0 & 0.0 & 152.0 \\
\hline 322: Paper Manufacturing & 9.8 & 105.3 & 22.2 & 85.0 & 35.0 & 2.5 & 2.0 & 0.0 & 1.4 & 0.0 & 0.0 & 0.0 & 0.0 & 0.0 & 0.0 & 0.0 & 0.0 & 0.0 & 263.2 \\
\hline $\begin{array}{l}\text { 323: Printing and Related } \\
\text { Support Activities }\end{array}$ & 3.0 & 32.0 & 7.0 & 3.0 & 1.0 & 0.5 & 3.0 & 0.1 & 0.1 & 0.1 & 0.0 & 0.0 & 0.0 & 0.0 & 0.1 & 0.0 & 1.0 & 0.0 & 50.9 \\
\hline $\begin{array}{l}\text { 324: Petroleum and Coal } \\
\text { Products Manufacturing }\end{array}$ & 12.5 & 34.1 & 109.7 & 80.0 & 60.0 & 399.0 & 10.6 & 8.5 & 4.2 & 307.6 & 0.0 & 0.0 & 2.6 & 0.0 & 0.0 & 3.2 & 0.0 & 0.0 & 1032.0 \\
\hline 325: Chemical Manufacturing & 104.5 & 172.8 & 80.7 & 80.0 & 20.0 & 20.0 & 9.0 & 4.0 & 50.1 & 35.1 & 0.0 & 0.0 & 2.0 & 3.0 & 0.8 & 3.0 & 1.0 & 14.0 & 600.0 \\
\hline $\begin{array}{l}\text { 326: Plastics and Rubber } \\
\text { Products Manufacturing }\end{array}$ & 4.5 & 5.1 & 9.0 & 2.2 & 0.8 & 0.5 & 0.2 & 0.0 & 0.0 & 0.0 & 0.0 & 0.0 & 0.0 & 0.0 & 0.5 & 0.0 & 0.0 & 0.0 & 22.8 \\
\hline $\begin{array}{l}\text { 327: Nonmetallic Mineral } \\
\text { Product Manufacturing }\end{array}$ & 2.1 & 24.2 & 16.7 & 35.0 & 24.0 & 6.0 & 0.0 & 0.7 & 0.0 & 0.0 & 0.3 & 0.0 & 0.0 & 0.0 & 0.0 & 0.0 & 0.0 & 0.0 & 108.9 \\
\hline $\begin{array}{l}\text { 331: Primary Metal } \\
\text { Manufacturing }\end{array}$ & 29.4 & 99.7 & 160.0 & 45.0 & 25.0 & 2.0 & 4.1 & 0.0 & 1.0 & 0.0 & 0.0 & 0.0 & 0.0 & 0.0 & 0.0 & 0.0 & 0.0 & 0.0 & 366.2 \\
\hline $\begin{array}{l}\text { 332: Fabricated Metal Product } \\
\text { Manufacturing }\end{array}$ & 9.8 & 103.2 & 22.1 & 100.0 & 41.9 & 7.0 & 2.0 & 0.0 & 1.0 & 1.0 & 0.0 & 0.0 & 0.0 & 0.0 & 0.0 & 0.0 & 0.0 & 0.0 & 288.0 \\
\hline 333: Machinery Manufacturing & 3.0 & 18.0 & 2.0 & 4.0 & 3.0 & 1.0 & 0.5 & 0.0 & 0.0 & 0.0 & 0.0 & 0.0 & 0.0 & 0.0 & 0.0 & 0.0 & 0.0 & 0.0 & 31.5 \\
\hline $\begin{array}{l}\text { 334: Computer and Electronic } \\
\text { Product Manufacturing }\end{array}$ & 7.5 & 7.2 & 1.0 & 2.0 & 0.7 & 0.0 & 0.0 & 0.0 & 0.0 & 0.0 & 0.0 & 0.0 & 0.0 & 0.0 & 0.0 & 0.0 & 0.0 & 0.0 & 18.4 \\
\hline $\begin{array}{l}\text { 335: Electrical Equipment } \\
\text { Manufacturing }\end{array}$ & 1.5 & 2.2 & 1.8 & 1.1 & 0.6 & 0.1 & 0.0 & 0.2 & 0.0 & 0.0 & 0.0 & 0.0 & 0.0 & 0.0 & 0.0 & 0.0 & 0.0 & 0.0 & 7.5 \\
\hline $\begin{array}{l}\text { 336: Transportation } \\
\text { Equipment Manufacturing }\end{array}$ & 3.8 & 14.0 & 2.3 & 8.2 & 1.1 & 1.0 & 0.0 & 0.0 & 0.0 & 0.0 & 0.2 & 0.0 & 0.0 & 0.0 & 0.0 & 0.0 & 0.0 & 0.0 & 30.6 \\
\hline $\begin{array}{l}\text { 337: Furniture and Related } \\
\text { Product Manufacturing }\end{array}$ & 1.5 & 4.8 & 0.7 & 2.1 & 0.3 & 0.5 & 0.1 & 0.0 & 0.0 & 0.0 & 0.0 & 0.0 & 0.0 & 0.1 & 0.0 & 0.0 & 0.0 & 0.0 & 10.1 \\
\hline $\begin{array}{l}\text { 339: Miscellaneous } \\
\text { Manufacturing }\end{array}$ & 1.4 & 4.8 & 0.8 & 2.2 & 0.3 & 0.5 & 0.1 & 0.0 & 0.0 & 0.0 & 0.0 & 0.0 & 0.0 & 0.1 & 0.0 & 0.0 & 0.0 & 0.0 & 10.2 \\
\hline TOTAL & 201.1 & 684.7 & 499.0 & 506.7 & 248.6 & 446.7 & 52.6 & 13.4 & 57.9 & 343.8 & 0.5 & 0.0 & 4.7 & 3.2 & 1.4 & 6.2 & 2.0 & 14.0 & 3086.4 \\
\hline
\end{tabular}


The DOE 2008 report presents waste heat inventory for selected manufacturing processes. The estimates of waste heat loss in exhaust gases were based on estimated fuel consumption and expected specific enthalpy (Btu/lb) of exhaust streams, which depends on temperature and chemical composition of the exhaust stream. Table 29 shows these results.

Evaluation of the two reports revealed some inconsistencies, in particular for the primary metals industries (including aluminum, iron and steel, and metal casting) and the nonmetallic mineral industries (including cement and glass). For some temperature ranges, data from ORNL 2004 was significantly lower than data from DOE 2008. In these instances, the more recent DOE 2008 data were used. Table $\mathbf{3 0}$ shows the final results for the non-metallic industry, and Table $\mathbf{3 1}$ shows the final results for the primary metals industry. 
Table 29. DOE 2008 Waste Heat Inventory ${ }^{58}$

\begin{tabular}{|c|c|c|c|c|c|c|}
\hline \multirow[t]{2}{*}{ Source } & \multirow{2}{*}{$\begin{array}{c}\text { Energy } \\
\text { Consumption } \\
\text { (TBtu / yr) }\end{array}$} & \multirow{2}{*}{$\begin{array}{c}\begin{array}{c}\text { Exhaust } \\
\text { Temperature }\end{array} \\
\left({ }^{\circ} \mathrm{F}\right)\end{array}$} & \multicolumn{2}{|c|}{$\begin{array}{l}\text { Waste Heat (TBtu/yr) @ } \\
\text { Reference Temperature }\end{array}$} & \multirow[t]{2}{*}{$\begin{array}{c}\text { Carnot } \\
\text { Efficiency }\end{array}$} & \multirow[t]{2}{*}{$\begin{array}{c}\text { Work Potentia } \\
\text { (TBtu / yr) }\end{array}$} \\
\hline & & & $\left(77^{\circ} \mathrm{F}\right)$ & $\left(300^{\circ} \mathrm{F}\right)$ & & \\
\hline Aluminum & 146.1 & -- & 9.5 & 6.7 & -- & 7.1 \\
\hline Primary & --- & --- & --- & --- & --- & --- \\
\hline Hall Heroult Cells & 134.6 & $1,292.0$ & 2.6 & 2.2 & $69 \%$ & 1.8 \\
\hline Secondary & --- & --- & --- & --- & --- & --- \\
\hline no Recovery & 9.3 & $2,100.0$ & 6.1 & 4.2 & $79 \%$ & 4.8 \\
\hline with Recovery & 2.2 & $1,000.0$ & 0.8 & 0.4 & $63 \%$ & 0.5 \\
\hline Iron/Steel Making & 828.6 & -- & 79.1 & 57.3 & --- & 52.3 \\
\hline Coke Oven & 65.5 & -- & --- & -- & -- & -- \\
\hline Gas & --- & $1,800.0$ & 15.8 & 13.9 & $76 \%$ & 12.1 \\
\hline Waste Gas & --- & 392.0 & 11.2 & 10.0 & $37 \%$ & 4.1 \\
\hline Blast Furnace & 642.3 & --- & --- & --- & --- & -- \\
\hline Blast Furnace Gas & --- & 200.0 & 5.3 & --- & $19 \%$ & 1.0 \\
\hline Blast Stove Exhaust & --- & --- & 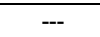 & --- & --- & -- \\
\hline no Recovery & 36.2 & 482.0 & 10.6 & 1.9 & $43 \%$ & 4.6 \\
\hline with Recovery & 34.1 & 266.0 & 3.2 & -- & $26 \%$ & 0.8 \\
\hline Basic Oxygen Furnace & 49.7 & $3,100.0$ & 27.1 & 26.0 & $85 \%$ & 23.0 \\
\hline Electric Arc Furnace & --- & --- & --- & --- & --- & --- \\
\hline no Recovery & 57.7 & $2,200.0$ & 5.8 & 5.4 & $80 \%$ & 4.6 \\
\hline with Recovery & 13.3 & 400.0 & 0.2 & 0.1 & $38 \%$ & 0.1 \\
\hline Glass Melting & 125.8 & --- & 43.0 & 24.1 & --- & 28.9 \\
\hline Regenerative & 54.4 & 800.0 & 15.1 & 6.5 & $57 \%$ & 8.7 \\
\hline Recuperative & 13.6 & $1,800.0$ & 7.6 & 5.4 & $76 \%$ & 5.8 \\
\hline OxyFuel & 12.8 & $2,600.0$ & 4.2 & 2.7 & $82 \%$ & 3.4 \\
\hline Electric Boost & 34.9 & 800.0 & 8.6 & 3.7 & $57 \%$ & 4.9 \\
\hline Direct Melter & 10.1 & $2,400.0$ & 7.5 & 5.8 & $81 \%$ & 6.1 \\
\hline Cement & 389.5 & -- & 83.1 & 44.3 & --- & 44.1 \\
\hline Wet kiln & 98.0 & 640.0 & 18.8 & 9.4 & $51 \%$ & 9.6 \\
\hline Dry kiln & 80.2 & 840.0 & 20.6 & 12.8 & $59 \%$ & 12.1 \\
\hline Preheater (only) & 67.8 & 640.0 & 13.9 & 7.0 & $51 \%$ & 7.1 \\
\hline Precalciner & 143.4 & 640.0 & 29.7 & 15.1 & $51 \%$ & 15.2 \\
\hline Metal Casting & 74.6 & --- & 32.8 & 24.0 & --- & 24.6 \\
\hline Aluminum & --- & --- & --- & --- & --- & --- \\
\hline Reverb Furnace & 19.0 & $2,100.0$ & 12.5 & 8.5 & $79 \%$ & 9.9 \\
\hline Stack Melter & 1.1 & 250.0 & 0.2 & --- & $24 \%$ & --- \\
\hline Iron Cupola & --- & --- & --- & --- & --- & --- \\
\hline no Recovery & 46.7 & $1,650.0$ & 19.3 & 15.3 & $75 \%$ & 14.4 \\
\hline with Recovery & 7.8 & 400.0 & 0.8 & 0.2 & $38 \%$ & 0.3 \\
\hline Boilers & $6,500.0$ & -- & $1,169.7$ & 100.0 & --- & 414.2 \\
\hline Conventional Fuels & -- & --- & -- & --- & --- & --- \\
\hline no Recovery & 812.5 & 500.0 & 173.8 & 36.5 & $44 \%$ & 76.6 \\
\hline with Recovery & $2,437.5$ & 300.0 & 394.3 & --- & $30 \%$ & 116.5 \\
\hline Byproduct Fuels & --- & --- & --- & --- & --- & --- \\
\hline no Recovery & 812.5 & 500.0 & 173.8 & 36.5 & $44 \%$ & 76.6 \\
\hline with Recovery & $2,437.5$ & 350.0 & 427.8 & 27.0 & $34 \%$ & 144.4 \\
\hline Ethylene Furnace & 374.0 & 300.0 & 60.5 & --- & $29 \%$ & 17.8 \\
\hline TOTAL & 8,439 & -- & 1,478 & 257 & $-\cdots$ & 589 \\
\hline
\end{tabular}

58 Data from DOE, 2008, Table 20, page 53. 
Table 30. Waste Heat Estimates for Non-Metallic Minerals Industry (TBtu / yr)

\begin{tabular}{|c|c|c|c|c|}
\hline \multirow{2}{*}{$\begin{array}{c}\text { Temperature } \\
\text { Range }\left({ }^{\circ} \mathrm{F}\right)\end{array}$} & \multicolumn{2}{|c|}{ ORNL 2004} & \multirow{2}{*}{$\begin{array}{c}\text { DOE } 2008 \\
\left(77^{\circ} \mathrm{F}\right)\end{array}$} & \multirow{2}{*}{$\begin{array}{c}\text { Final Estimate } \\
\left(77^{\circ} \mathrm{F}\right)\end{array}$} \\
\hline & $\left(60^{\circ} \mathrm{F}\right)$ & $\left(77^{\circ} \mathrm{F}\right)$ & & \\
\hline$<100$ & 2.1 & 0.0 & --- & 0.0 \\
\hline $100-200$ & 24.2 & 19.6 & --- & 19.6 \\
\hline $200-300$ & 16.7 & 15.2 & --- & 15.2 \\
\hline $300-400$ & 35.0 & 32.9 & --- & 32.9 \\
\hline $400-500$ & 24.0 & 23.0 & --- & 23.0 \\
\hline $500-600$ & 6.0 & 5.8 & --- & 5.8 \\
\hline $600-700$ & 2.5 & 2.4 & 62.4 & 62.4 \\
\hline $700-800$ & 0.7 & 0.6 & --- & 0.6 \\
\hline $800-900$ & 0.5 & 0.5 & 44.3 & 44.3 \\
\hline $900-1000$ & 0.0 & 0.0 & --- & 0.0 \\
\hline $1000-1100$ & 0.3 & 0.3 & --- & 0.3 \\
\hline $1100-1200$ & 0.0 & 0.0 & --- & 0.0 \\
\hline $1200-1300$ & 0.0 & 0.0 & $\begin{array}{ll}-- \\
\end{array}$ & 0.0 \\
\hline $1300-1400$ & 0.0 & 0.0 & --- & 0.0 \\
\hline $1400-1500$ & 0.0 & 0.0 & --- & 0.0 \\
\hline $1500-1600$ & 0.0 & 0.0 & $\begin{array}{ll}-- \\
\end{array}$ & 0.0 \\
\hline $1600-1700$ & 0.0 & 0.0 & --- & 0.0 \\
\hline $1700-1800$ & 0.0 & 0.0 & --- & 0.0 \\
\hline $1800-1900$ & 0.0 & 0.0 & 7.6 & 7.6 \\
\hline $1900-2000$ & 0.0 & 0.0 & --- & 0.0 \\
\hline $2000-2100$ & 0.0 & 0.0 & --- & 0.0 \\
\hline $2100-2200$ & 0.0 & 0.0 & --- & 0.0 \\
\hline $2200-2300$ & 0.0 & 0.0 & --- & 0.0 \\
\hline $2300-2400$ & 0.0 & 0.0 & --- & 0.0 \\
\hline $2400-2500$ & 0.0 & 0.0 & 7.5 & 7.5 \\
\hline $2500-2600$ & 0.0 & 0.0 & --- & 0.0 \\
\hline $2600-2700$ & 0.0 & 0.0 & 4.2 & 4.2 \\
\hline$>2700$ & 0.0 & 0.0 & 0.0 & 0.0 \\
\hline Total & 112.0 & 100.4 & 126.0 & 223.4 \\
\hline
\end{tabular}


Table 31. Final Waste Heat Estimates for Primary Metals Industry (TBtu / yr)

\begin{tabular}{|c|c|c|c|c|}
\hline \multirow{2}{*}{$\begin{array}{c}\text { Temperature } \\
\left.\text { Range ( }{ }^{\circ} \mathrm{F}\right)\end{array}$} & \multicolumn{2}{|c|}{ ORNL 2004} & \multirow{2}{*}{$\begin{array}{c}\text { DOE } 2008 \\
\left(77^{\circ} \mathrm{F}\right)\end{array}$} & \multirow{2}{*}{$\begin{array}{c}\text { Final Estimate } \\
\left(77^{\circ} \mathrm{F}\right)\end{array}$} \\
\hline & $\left(60^{\circ} \mathrm{F}\right)$ & $\left(77^{\circ} \mathrm{F}\right)$ & & \\
\hline$<100$ & 29.4 & 0.0 & --- & 0.0 \\
\hline $100-200$ & 99.7 & 80.9 & --- & 80.9 \\
\hline $200-300$ & 160.0 & 145.7 & 8.7 & 145.7 \\
\hline $300-400$ & 45.0 & 42.4 & 11.2 & 42.4 \\
\hline $400-500$ & 25.0 & 23.9 & 11.6 & 23.9 \\
\hline $500-600$ & 2.0 & 1.9 & --- & 1.9 \\
\hline $600-700$ & 4.1 & 4.0 & $\begin{array}{ll}-- \\
\end{array}$ & 4.0 \\
\hline $700-800$ & 0.0 & 0.0 & --- & 0.0 \\
\hline $800-900$ & 1.0 & 1.0 & --- & 1.0 \\
\hline $900-1000$ & 0.0 & 0.0 & --- & 0.0 \\
\hline $1000-1100$ & 0.0 & 0.0 & 0.8 & 0.8 \\
\hline $1100-1200$ & 0.0 & 0.0 & --- & 0.0 \\
\hline $1200-1300$ & 1.7 & 1.7 & 2.6 & 2.6 \\
\hline $1300-1400$ & 0.0 & 0.0 & --- & 0.0 \\
\hline $1400-1500$ & 0.0 & 0.0 & --- & 0.0 \\
\hline $1500-1600$ & 0.0 & 0.0 & --- & 0.0 \\
\hline $1600-1700$ & 0.0 & 0.0 & 19.3 & 19.3 \\
\hline $1700-1800$ & 0.0 & 0.0 & 15.8 & 15.8 \\
\hline $1800-1900$ & 0.0 & 0.0 & $\begin{array}{ll}--- \\
\end{array}$ & 0.0 \\
\hline $1900-2000$ & 0.0 & 0.0 & $\begin{array}{c}-- \\
\end{array}$ & 0.0 \\
\hline $2000-2100$ & 0.0 & 0.0 & --- & 0.0 \\
\hline $2100-2200$ & 0.0 & 0.0 & 18.6 & 18.6 \\
\hline $2200-2300$ & 0.0 & 0.0 & 5.8 & 5.8 \\
\hline $2300-2400$ & 0.0 & 0.0 & --- & 0.0 \\
\hline $2400-2500$ & 0.0 & 0.0 & --- & 0.0 \\
\hline $2500-2600$ & 0.0 & 0.0 & --- & 0.0 \\
\hline $2600-2700$ & 0.0 & 0.0 & --- & 0.0 \\
\hline$>2700$ & 0.0 & 0.0 & 27.1 & 27.1 \\
\hline Total & 368.0 & 301.5 & 94.4 & 362.7 \\
\hline
\end{tabular}




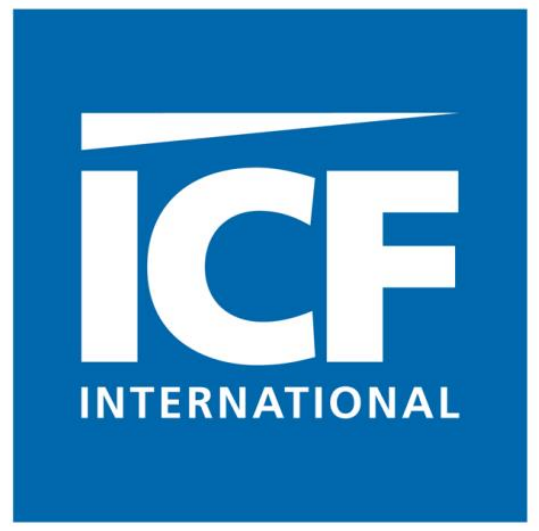

PASSION. EXPERTISE. RESULTS.

www.icfi.com

\section{Headquarters}

ICF International

9300 Lee Highway

Fairfax, Virginia 22031 